DOE/EH-0493

PB95 -

BNL -52470

Ju1y 1995

\title{
MEDICAL STATUS OF MARSHALLESE ACCIDENTALLY EXPOSED TO 1954 BRAVO FALLOUT RADIATION; JANUARY 1988 THROUGH DECEMBER 1991
}

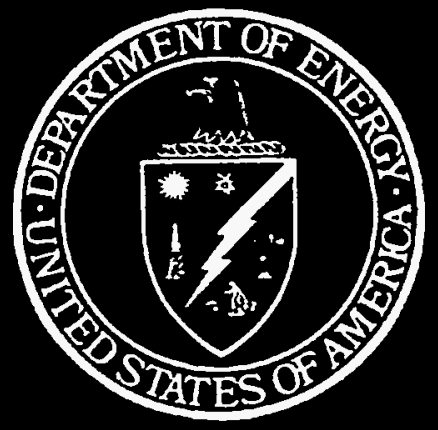

July 1995

Prepared for U.S. Department of Energy OFFICE OF ENVIRONMENT, SAFETy AND HEalth OfFice of International Health Studies

Under Contract No. DE-ACO2-76CH00016 


\section{DISCLAIMER}

This report was prepared as an account of work sponsored by an agency of the United States Govemment. Neither the United States Government nor any agency thereof, nor any of their employees, makes any warranty, express or implied, or assumes any legal liability or responsibility for the accuracy, completeness, or usefulness of any information, apparanus, procisct, or process disclosed, or represents that its use would not infringe privately owned rights. Reference herein to any specific commercial product, process, or service by trade name, trademark, manufacturer, or otherwise does not necessarily constiute or imply its endorsement recommendation, or favoring by the United States Govenment or any agency thereof. The views and opinions of authors expressed herein do not necessarily state or reflect those of the United States Government or any agency thereof.

This report has been reproduced directly from the best available copy.

Available to DOE and DOE Contractors from the Office of Scientific and Technical Information, P.O. Box 62, Oak Ridge, TN 37831; prices available from (615) $576-8401$.

Available to the public from the U.S. Department of Commerce, Technology Administration, National Technical Information Service, Springfield, VA 22161 , (703) $487-4650$. 


\section{MEDICAL STATUS OF MARSHALLESE ACCIDENTALLY EXPOSED TO 1954 BRAVO FALLOUT RADIATION; JANUARY 1988 THROUGH DECEMBER 1991}

\section{By}

J.E. Howard, M.D.; P.M. Heotis; W.A. Scott; and W.H. Adams, M.D. Brookhaven National Laboratory Medical Department Upton, New York 11973

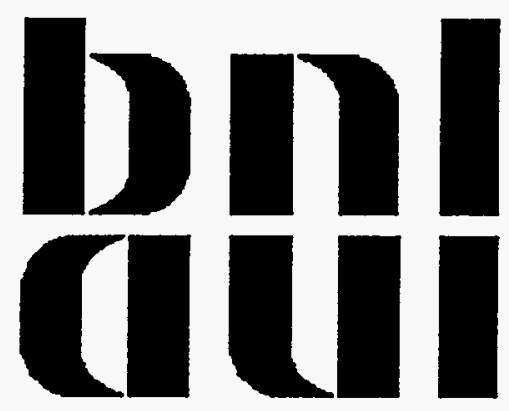

JuTy 1995

Work Performed Under Contract No. DE-ACO2-76CH00O16

Prepared for

U.S. Department of Energy

Assistant Secretary for Environment, Safety and Health Office of Health 


\section{DISCLAIMER}

Portions of this document may be illegible in electronic image products. Images are produced from the best available original document. 


\section{FOREWORD}

As part of the United States atmospheric nuclear weapons testing program between 1946 and 1958, 23 nuclear devices were detonated at the Bikini Atoll and 43 nuclear devices were detonated at the Enewetak Atoll. A 1954 nuclear weapons test on the Bikini Atoll, test shot code named Castle Bravo, produced a nuclear yield much higher than anticipated. The levels and dispersion of the radioactive fallout from Castle Bravo were significantly greater than originally expected. This resulted in radioactive fallout on the inhabited atolls of Rongelap and Utrik. The Rongelap and Utrik people were evacuated from their contaminated atolls 48 and 72 hours, respectively, after the Castle Bravo test shot. The original population directly exposed to the fallout from Castle Bravo consisted of 241 individuals and 12 fetuses. Absorbed dose estimates for the exposed population were in the order of 0.11 to 1.9 Gray (11 to $190 \mathrm{Rad}$ ) to the whole body and from 1.9 to 200 Gray (190 to 20,000 Rad) to the thyroid.

Public Law 99-239 mandated that the Government of the United States would "continue to provide special medical care and logistical support to...the remaining population of the Rongelap and Utrik who were exposed to radiation resulting from the 1954 Bravo test." The Department of Energy (DOE), through its contract with the Brookhaven National Laboratory Medical Department, implements this congressional mandate.

The present DOE Marshall Islands medical surveillance program consists of two field missions per year. The purpose of the program is to provide medical care and treatment for radiologically related problems for those Marshallese who were exposed to fallout from the 1954 Castle Bravo test. As of December 1991, the originally exposed population consisted of 159 individuals. The medical surveillance program offers, on a voluntary participation basis, an annual physical examination to these individuals, as well as annual physical examinations to a comparison/control unexposed population.

The medical surveillance procedure includes a complete annual physical examination, which is based on the criteria established by the American Cancer Society. Typical medical missions included specialists in gastroenterology, hematology, obstetrics/gynecology, endocrinology, oncology, radiology, cardiology, nephrology, pulmonology, and rheumatology.

This, the 16th report of the Marshall Islands Medical Program, disseminates information concerning the medical status of the 253 Marshallese exposed to the fallout from the 1954 Castle Bravo test shot.
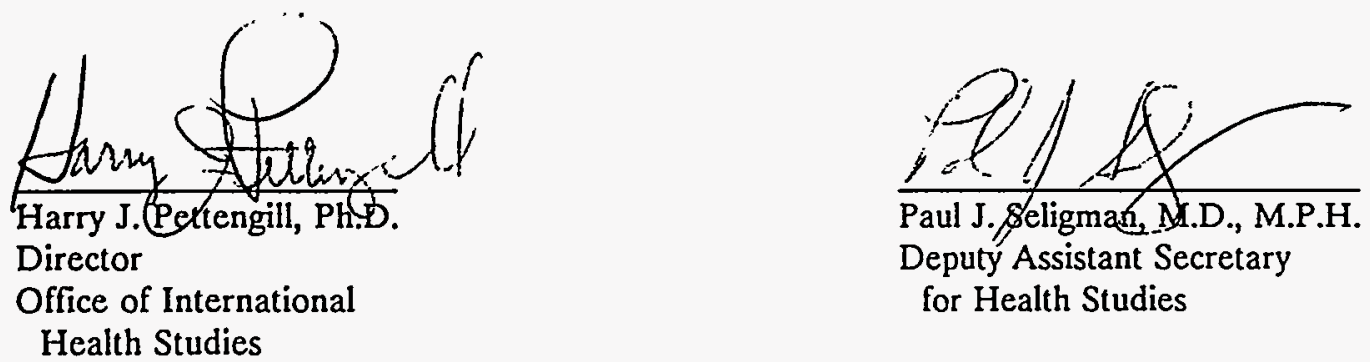


\section{EXECUTIVE SUMMARY}

\section{$\underline{\text { Introduction }}$}

As a result of the radiation exposure of individuals on the Marshall Islands atolls of Rongelap and Utrik shortly after test shot Castle Bravo, the United States began providing surveillance and health care associated with radiation related diseases to those individuals exposed. This responsibility was codified into law by Public Law 95-134 (1977) and Public Law 99-239 (1986). The distribution of the initially exposed group was as follows: 64 persons on Rongelap, plus 3 fetuses; 18 persons on Ailingnae, plus 1 fetus; and 159 persons on Utirik, plus 8 fetuses. In later years, the Ailingnae have been combined into the Rongelap population. The Department of Energy's (DOE) Office of Environment, Safety and Health is responsible for ensuring that the Marshallese who were exposed to radiation during Castle Bravo in 1954 receive medical care and treatment for any injury, illness, or condition that may be the result, directly or indirectly, from their exposure to the fallout from Castle Bravo. For the last 37 years, the Brookhaven National Laboratory (BNL), under contract to DOE, has provided the required health care and surveillance for this program. In addition to conducting surveillance of the exposed Marshallese group, BNL has been monitoring a cohort of unexposed Marshallese. The individuals in this cohort were selected to mirror the age, sex, etc., distribution of the exposed group. Currently, there are approximately 154 of the exposed population and 115 of the unexposed population being monitored. This report discusses the medical care provided and the medical findings for the years 1988-1991.

\section{Procedure}

In the spring and fall of each year, the BNL medical team visits the islands of Mejatto, Utrik, Ebeye, and Majuro to provide medical surveillance to the exposed and unexposed cohorts. The medical team is composed of BNL personnel, DOE Headquarters personnel, staff of the Marshallese Government Health Services, and volunteer physicians from various universities and government and private institutions in the United States. The medical team travels from island to island on a DOE leased vessel. The vessel has examination facilities and is capable of doing basic laboratory work. Blood samples for more complex tests, such as Thyroid Stimulating Hormone tests, are frozen and taken to BNL. The following examinations are performed during the medical visits:

A. A cancer-related examination as defined by the American Cancer Society;

- A review of systems and a complete medical examination;

o Pelvic examinations with Papanicolaou smears;

o Stool testing for occult blood;

- A mammogram for females;

- A flexible sigmoidoscopy for females and males; and

o Advice on decreasing risk factors and on self-detection of lesions.

B. An annual thyroid examination and thyroid function testing;

C. Serum prolactin testing looking for pituitary tumors;

D. Annual blood counts to include platelets; and

E. Evaluation for paraneoplastic evidence of neoplasms. 


\section{Medical Findings}

During the last 4 years, 95 percent of the exposed population from Rongelap, 98 percent of the exposed population from Utrik, and 90 percent of the comparison population have been examined at least once. Those persons not residing in the Marshall Islands are seen by a physician in their locality.

After 37 years, there is little difference between the longevity curves of the Rongelap group, the Utirik group, and the unexposed cohort population. Each of the deaths (4 exposed and 10 nonexposed) that have occurred during the report period is discussed later in the report. The Marshallese population has a high incidence of diabetes, and it appears that one of the deaths of the exposed population and five of the deaths of the unexposed population were diabetes related.

There is a mild, but relatively consistent depression of neutrophil, lymphocyte, and platelet concentrations in the blood of the exposed population. This depression appears to be of no clinical significance. Thyroid hypofunction, either clinical or biochemical, has been documented as a consequence of radiation exposure in 14 exposed Rongelap individuals. During this reporting period, one exposed person was diagnosed as having a basal cell carcinoma. Previously, one other exposed person had been diagnosed as having basal cell carcinoma. During this reporting period, a thyroid nodule was identified in an individual who was one of those who was in utero at the time of the exposure. Upon pathologic review, the nodule was diagnosed as occult papillary carcinoma. 


\section{DEDICATION}

This report is dedicated to Dr. Brown M. Dobyns, M.D., Ph.D. Dr. Dobyns first volunteered to serve as thyroid surgeon and consultant to the Marshall Islands Medical Program in 1969. He subsequently participated in ten medical missions to the Marshall Islands. Dr. Dobyns' compassion, skill, respect for Marshallese customs, and personal involvement with the welfare of our Marshallese patients tempered the emotional and physical duress of undergoing thyroid surgery at a major U.S. medical center where the number of hospital employees alone far exceeded the population of their home island. His concern and graciousness were amplified in the warmth and courtesy of the staff of Cleveland Metropolitan General Hospital, particularly that of the Surgical Service.

Dr. Dobyns recently retired from his position in the Department of Surgery, Case Western Reserve University, where he is currently Emeritus Professor of Surgery. One of his undertakings since retirement has been the publication of a comprehensive review of approximately eighty thyroid surgeries performed on the Marshallese during his involvement with the Brookhaven medical program (Dobyns and Hyrmer, 1991). Although our thyroid surgeries are now performed at the Clinical Center, the National Institutes of Health, we know that Dr. Dobyns will continue to extend to us the benefits of his medical wisdom and, occasionally, the pleasure of his company. 


\section{CONTENTS}

Page

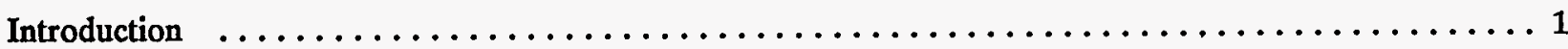

Exposure Groups $\ldots \ldots \ldots \ldots \ldots \ldots \ldots \ldots \ldots \ldots \ldots \ldots \ldots \ldots \ldots \ldots \ldots \ldots \ldots \ldots \ldots$

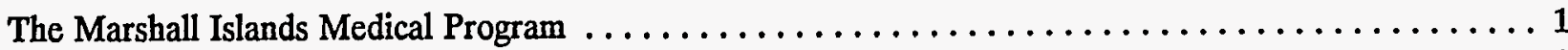

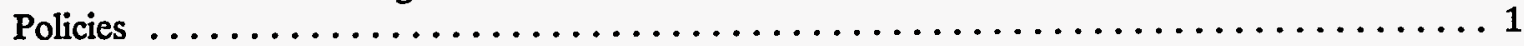

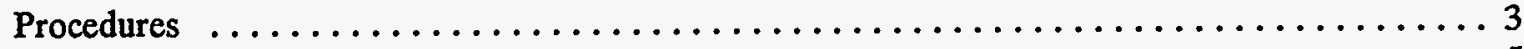

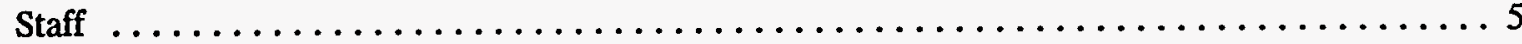

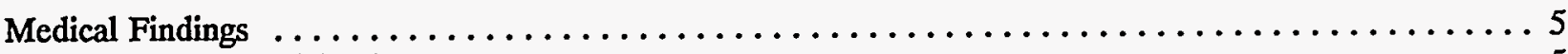

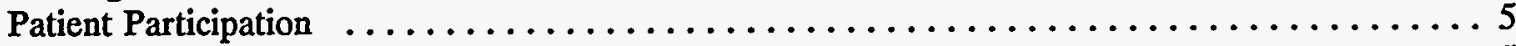

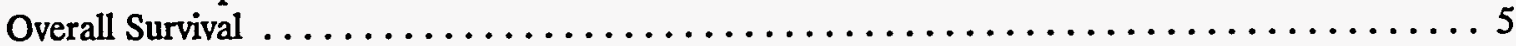

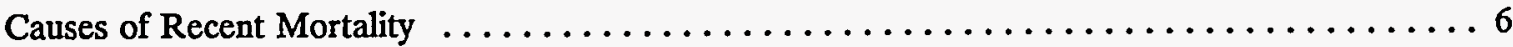

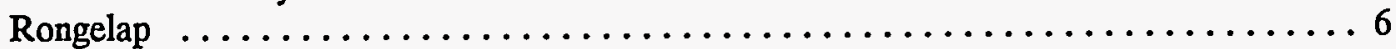

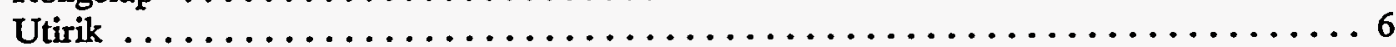

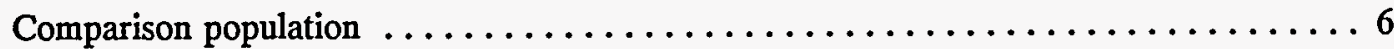

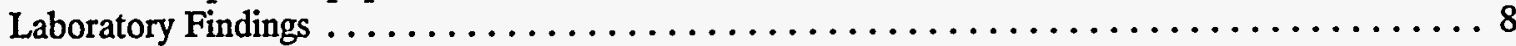

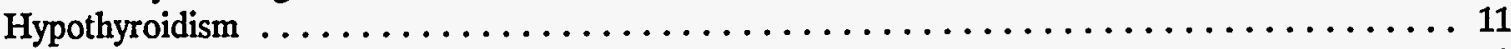

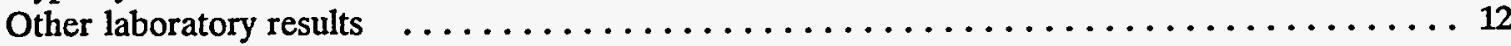

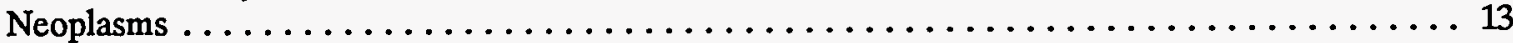

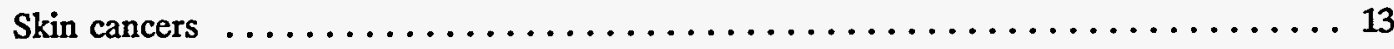

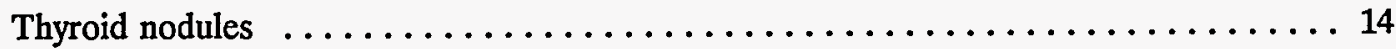

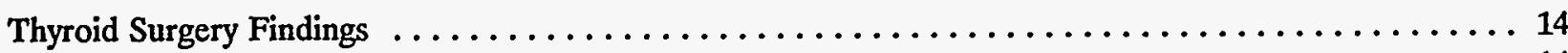

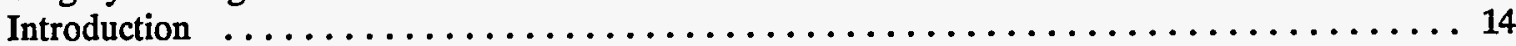

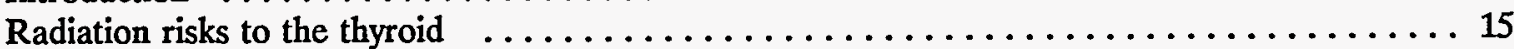

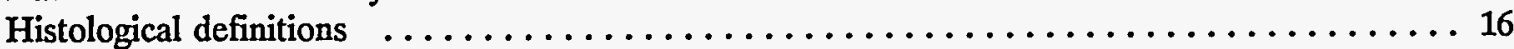

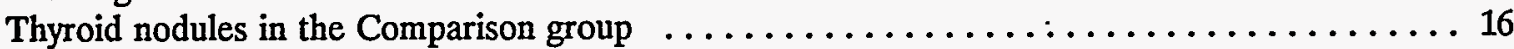

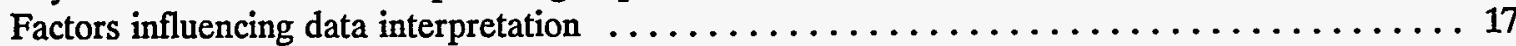

Issues that can be addressed without invoking

data from the Comparison group $\ldots \ldots \ldots \ldots \ldots \ldots \ldots \ldots \ldots \ldots \ldots \ldots \ldots \ldots \ldots$

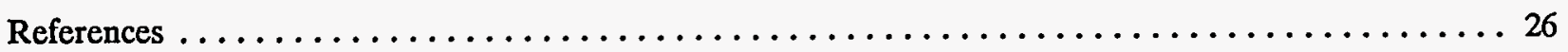

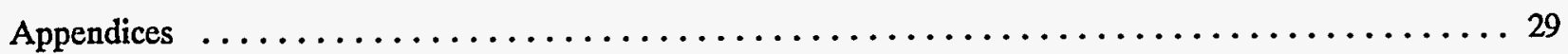




\section{INTRODUCTION}

This is the 16th report of the Marshall Islands Medical Program prepared by Brookhaven National Laboratory (BNL). The purpose of these publications is to disseminate information concerning the medical status of 253 Marshallese exposed to fallout radiation in 1954. In so doing, the medical program is fulfilling a commitment incumbent on all health care organizations; i.e., to disclose in a timely fashion unique medical information relevant to the public health. Details of the BRAVO thermonuclear accident that caused the exposure have been published, and a 1955 article in the Joumal of the American Medical Association describing the acute medical effects in the exposed population remains a definitive and relevant description of events (Cronkite et al., 1955).

Participation in the Marshall Islands Medical Program by the exposed Marshallese is voluntary. Throughout the 36 years of this program, each participating exposed individual's relevant medical findings, laboratory data, and disease morbidity and mortality have been published in the Brookhaven reports in a manner preserving patient confidentiality. Also, in each report, there has been an attempt to interpret these findings and to infer the role of radiation exposure in their development. But an equally important aspect of the reports has been presentation of the actual data so that readers can apply their own analyses to questions pertaining to the medical consequences of the Marshallese exposure.

\section{EXPOSURE GROUPS}

The exposed Marshallese population originally was comprised of 64 persons on Rongelap Atoll who each received an estimated $190 \mathrm{cGy}$ of wholebody external gamma radiation, 18 on Ailingnae Atoll (Sifo island) who each received $110 \mathrm{cGy}$, and 159 on Utirik Atoll who each received 11 cGy. In addition, there were 12 women who were pregnant at the time of the accident ( 3 on Rongelap, 1 on Ailingnae, and 8 on Utirik), each of whom received whole-body doses equivalent to others in the same atoll. The twelve individuals exposed in utero became a part of the exposed population after birth. Because of radioiodines in the fallout, the thyroid gland received an exposure that was much greater than the whole-body dose, the magnitude of which was a function of age at the time of exposure (Lessard et al., 1985). In December 1991, the number of surviving exposed persons was: Rongelap - 48, Ailingnae - 11, and Utirik - 100. For most purposes in this report the Rongelap and Ailingnae groups are treated as one and referred to as the Rongelap group, because those persons exposed to fallout on Ailingnae were Rongelap inhabitants temporarily residing on this nearby atoll.

The Marshall Islands Medical Program also examines a comparison group that dates from 1957 when 86 unexposed people from Rongelap were selected. The makeup of the group approximated, in age and gender, that of the exposed Rongelap population (Conard et al., 1958). In December 1991, 56 persons remained in this group. From 1962 to 1978 additional persons were added as a second comparison group in order to supplement and replace persons lost from the original group. This group was also matched by age and gender to the exposed population and was similar to the 1982 Rongelap and Utirik exposed groups. In December 1991, the total population of the two comparison groups was 115. As in previous reports, it is the expanded unexposed population that is used in this report for comparisons of year-to-year medical events and for causes of death; this provides baseline prevalences of disease in the community from which unexpected consequences of the fallout exposure can be identified. They are also used to compare survival rates of the exposed population to the unexposed population.

\section{THE MARSHALL ISLANDS MEDICAL PROGRAM}

\section{Policies:}

The mandate of the program, as formulated by the U.S. Congress most recently in 1980 (PL 96-205, Sec. 106 (a)), specifies "...a program of medical care and treatment....for any injury, illness, or condition which may be the result directly or indirectly of such nuclear weapons testing program." Subsequently, in 1985, the Compact of Free Association between the U.S. and the Republic of the Marshall Islands provided for radiation injury compensation to be managed by the Marshallese themselves. However, a subsidiary agreement, in 
response to a request from the Republic of the Marshall Islands, has permitted the Brookhaven medical program to continue to supplement local health care for the exposed persons, stating "..the President....shall continue to provide special medical care and logistical support thereto for the remaining 174 members of the population of Rongelap and Utirik who were exposed to radiation resulting from the 1954 United States thermonuclear "Bravo" test, pursuant to Public Laws 95-134 and 96-205."

The Marshall Islands Medical Program is a clinical program which exists for the benefit of the radiation-exposed Marshallese. It is a program of radiation-related disease surveillance consisting of periodic examination and treatment of disease. Additionally, clinical investigations have been carried out by the program over the years, the intent being to identify present or future threats to the health of the exposed Marshallese, hopefully in time to prevent or limit morbidity and mortality. For example, based on the medical program's early findings of numerous thyroid nodules in the exposed population, thyroxine suppression was initiated for the Rongelap people in 1965 so that thyroid nodules/carcinoma might be prevented. It is possible that this prophylaxis has met with some success. This will be discussed in detail below.

The Marshall Islands Medical Program is distinct from the Marshallese Government Health Services, which is a national program of health care which encompasses two hospitals and a network of clinics scattered over some 20 atolls. This network serves the entire population of the Marshall Islands, which numbers over 45,000, whereas the U.S.-funded medical program is directed to assist only those individuals who were exposed to fallout radiation from the BRAVO accident.

The Marshall Islands Medical Program provides medical care twice yearly to the exposed and comparison populations by visiting the islands where most now reside, namely Mejatto, Utirik, Ebeye, Majuro, and, prior to 1985, Rongelap.

Any exposed person who has medical findings suggesting a malignant neoplasm, or other radiation related disease, is referred to secondary or tertiary medical facilities for definitive evaluation and therapy. Those persons with problems that can be effectively managed in Majuro are referred to the Marshallese Health
Services. Those requiring a more extensive evaluation are referred to hospitals in Honolulu or, for the special cases of thyroid and pituitary lesions, the National Institutes of Health in. Bethesda, Maryland. Individuals needing referral for nonradiation related problems are referred to the Marshallese Health Service where immediate treatment is initiated.

During the process of providing medical surveillance to the exposed Marshallese, the physicians of the medical program come into contact with children and other family members of the exposed, as well as other inhabitants of the islands. It has been the policy of the Department of Energy to support the medical program in its efforts to provide medical consultations by the medical specialists on the mission to these individuals on the basis of humanitarian need and as resources permit. In addition, services of the Brookhaven medical team and its facilities are offered to the Ebeye and Majuro hospitals. On most visits lectures by team physicians are arranged and patients referred from the hospitals are evaluated.

The medical direction of the Marshall Islands Medical Program and the organization of the medical missions to the Marshall Islands are centered at Brookhaven National Laboratory. The staff of the program includes a physician-director, an administrator, and a medical associate at the Laboratory, and a Marshallese laboratory technician on Ebeye. At the time of the missions a variety of physicians are chosen for the medical team. They are skilled volunteers, primarily selected from the staff of university-affiliated or government hospitals, and often with past experience with the program. Direct management of thyroid disease at the time of medical examination is in the hands of the endocrinologist on the medical team. Dr. Jacob Robbins, Chief of the Endocrinology Section, Genetics and Biochemistry Branch, National Institutes of Health, Bethesda, MD. provides overall management of the thyroid disease facet of the medical program. Raytheon Services Nevada, Inc., Honolulu, Hawaii, under contract to DOE, provides excellent logistical support to the Department of Energy. The Marshall Islands government, provides on request, nurses, translators, and other health care workers for each mission.

In the interim between the two medical missions the exposed population has access to the Marshallese health care system. To expedite exchange of medical information, with the 
permission of the examinees, copies of all examination and laboratory data from the Brookhaven program are forwarded to the Marshall Islands Health Service hospitals on Ebeye and Majuro and to the 177 Health Care Program, a special program set up for persons from the radiation-affected atolls, with administrative offices at the Majuro hospital. In addition, copies of the examinations and laboratory data are given to the examinees themselves.

The Marshall Islands Medical Program, as a satellite clinic of the Clinical Research Center, Brookhaven National Laboratory, is accredited by the Joint Commission on Accreditation of Healthcare Organizations, a nationwide organization that sets standards of performance for institutions dispensing medical care and monitors compliance with those standards. By voluntarily participating in the accreditation process, the Brookhaven National Laboratory Marshall Islands Medical Program receives a valuable and impartial external review of its policies and procedures, as well as an assessment of the adequacy of the services it provides. Laboratory and radiological services, medical records, patient satisfaction, pharmaceutical services, and clinical competence of physicians are among the many items reviewed by the Joint Commission.

\section{Procedures:}

The exposed population, which in December 1991 numbered 159, must be considered at increased risk for malignant disease as a late complication of radiation exposure. Therefore, the medical program has in place a canceroriented annual health evaluation. The examination follows the guidelines of the American Cancer Society and includes a medical history, complete physical examination, advice on decreasing the risk factors for cancer, advice on self-detection of lesions, annual pelvic examinations and Papanicolaou smears, blood count, urinalysis, stool testing for occult blood, annual mammography (offered to all exposed women and to all unexposed women forty years of age or older), and flexible sigmoidoscopy (every three years for persons fifty years of age or older).

Every two years ophthalmologists are included on the medical team and slit-lamp examinations are provided. A wide selection of reading glasses and glasses for aphakic individuals are included on each mission. These glasses, of great practical value to the island populations, have for years been kindly provided free of charge by New Eyes for the Needy (P.O. Box 332, Short Hills, NJ).

It is known, because of earlier medical program observations, that the exposed are at increased risk for certain endocrine problems. Therefore, they receive annual thyroid function blood tests and thyroid examinations by a specialist in endocrinology or thyroid surgery. Needle biopsies of thyroid nodules were performed on selected patients in an effort to avoid surgery and the subsequent loss of normal thyroid tissue. Other serologic tests are performed on a regular basis in an attempt at early detection of malignant nonthyroidal lesions. These include serum protein electrophoresis, calcium, prolactin, alpha-fetoprotein levels on persons known to have hepatitis B surface antigenemia, and thyroglobulin determinations on those whose thyroid surgery specimens suggested a malignant lesion. There is also ongoing monitoring for clinical evidence of immune competence, for exposed persons may be at increased risk for infectious disease or unusual manifestations thereof. Specialized tests on the comparison population were referred as clinically indicated.

Medical examinations and services performed during this four-year reporting period were conducted primarily aboard the Liktanur III, owned by U.S. Oceanography, San Diego, CA, and the G. W. Pierce, a vessel owned by Tracor Marine, Ft. Lauderdale, FL. These ships were chartered by the U.S. Department of Energy for the purpose of supporting several of the Department of Energysponsored Marshall Islands programs, of which the medical program is but one. Some patients were examined in the island dispensaries on Mejatto and Utirik, and home visits were arranged for the elderly who preferred not to be moved aboard the ship.

Clinical laboratory services for the missions were performed by several Brookhaven National Laboratory technicians with support from personnel of the Health Services of the Republic of the Marshall Islands. Routine hematology testing was performed on a J.T. Baker 5000 electronic counter and, beginning in the fall of 1989 , on the Serono Baker $9000 \mathrm{RX}$ automatic 8-parameter cell counter. Leukocyte differentials and platelet counts were part of each evaluation. Clinical chemistry tests were 
performed on Eastman Kodak EktaChem DT60, DTSC or DTE analyzers. These analyzers provide a wide variety of basic chemistry tests with a small amount of disposable waste. Urinalysis included a dip-stick examination and, when indicated, microscopic analysis. Stool exams were performed on physicians' request for identification of parasites and occult blood, although the physicians routinely perform a test for occult blood at the time of examination.

Roentgenographic services were provided using a dedicated mammography unit and a standard $x$ ray unit manufactured by the Bennett Corporation, Long Island, NY. X-ray interpretation was done at the time of examination. However, if no radiologist was part of the medical team, the $x$-ray films were returned to Brookhaven National Laboratory and then referred to a consultant radiologist, Dr. R. Naylor, at the University of Vermont.

A portable, battery powered, electrocardiograph machine was available. Electrocardiogram interpretation was done at the time of examination, with a copy often being given to the patient. All electrocardiograms were subsequently returned to Brookhaven National Laboratory and then referred to a consultant cardiologist (Dr. M. Zema) at Brookhaven Memorial Hospital on Long Island, NY, for definitive analysis.

In recent years an ultrasound machine (Hewlett Packard Sonos 100) has been available on the ship for assessment of such diverse items as abdominal pain, hematuria, gestational age, and cardiac disease. It is used only when a radiologist or subspecialist physician with expertise in ultrasound examination is part of the team. Ultrasound has been available to confirm findings on physical examination of the thyroid but this requires special planning and an investigator experienced in thyroid ultrasound. It was not used to screen for subclinical thyroid nodularity.

Sera collected during the routine physical examinations were analyzed at the time of patient examination, as clinically indicated. The remainder was frozen for further testing upon return to Brookhaven National Laboratory. The latter tests were performed at the Brookhaven Clinical Laboratory or referred to university and commercial laboratories. Among the referral laboratories were: Hazelton Washington, Inc., Vienna, VA, for hormone assays; Michael Reese
Hospital and Medical Center (Dr. A.B Schneider, Division of Endocrinology and Metabolism), Chicago, IL for thyroglobulin analysis; MetPath, Teterboro, NJ; Smith Kline Beecham (Accupath), Honolulu, HI; and Smith Kline Bio-Science, King of Prussia, PA. Pathologists' Laboratories, Inc. in Aiea, HI, was the primary source for Papanicolaou smear and cytology interpretations.

Quality control/quality assurance is an important focus of the medical program. Accreditation by the Joint Commission on Accreditation of Healthcare Organizations is one manifestation of this. In the laboratory quality control and quality assurance involves routine calibration, maintenance and monitoring of all instrumentation. Daily tri-level analysis of reference materials is performed on the hematology analyzer. The chemistry analyzer is calibrated prior to each mission, and bi-level quality control samples are run on all analyses. Approximately 10 percent of all chemistry tests performed in the field are re-analyzed at Brookhaven National Laboratory to compare with and to confirm the earlier results all of which proved to be within acceptable tolerance. When necessary, laboratory instrumentation is inspected and repaired by company service representatives. Other instrumentation, such as sphygmomanometers, electrocardiograph machines, doppler units, are periodically calibrated and have routine preventative maintenance performed at Brookhaven National Laboratory between missions.

Other quality assurance methods include the use of questionnaires given to patients. These questionnaires, translated into Marshallese, with the responses being interpreted at the present time by Mr. Alfred Capelle, Director of the Marshall Islands Alele Museum in the Republic of the Marshall Islands in Majuro, solicit criticism and advice for improving the medical program's operation. One important quality assurance mechanism is the involvement of volunteer physicians from around the United States, for this rotation through the program of new medical eyes and ears keeps the medical program attuned to newer or better approaches to diagnosis and management. In addition to information obtained by personal interaction during the missions, ideas for bettering the program are requested via a questionnaire distributed to all professional personnel at the end of each mission. Finally, the results of these and other mechanisms of quality assurance are reviewed by the Brookhaven National Laboratory Clinical Research 
Center Quality Assurance and Care Committee. Also included in that review are items such as the appropriateness of the use of anti-infective agents. A certified medical records consultant randomly reviews approximately 20 percent of our records for accuracy and completeness.

\section{Staff:}

The Marshall Islands Medical Program is deeply indebted to the many outstanding physicians who, despite the inevitable personal inconvenience, participated in the medical team visits of 1988-1991. It is fair to say that they are the heart of the program. Drawn from excellent medical centers through the United States and from private practices, these physicians provide the program with a wide range of up-to-date clinical experience and perspective that contribute to better patient care. The physicians and other medical team personnel involved in the 1988-1991 missions are listed in Appendix A. The clinical role of team physicians is the delivery of primary and subspecialty care. By selecting subspecialists who remain active in general medicine for this role, the medical program benefits from in-depth knowledge of their specialty. The following medical specialties and subspecialties were represented in 1988-1991:

Internal Medicine
Pediatrics
Cardiology
Rheumatology
Radiology
Gastroenterology
Hematology
Endocrinology
Surgery
Ophthalmology
Obstetrics/Gynecology
Pulmonary Medicine
Emergency Medicine
Oncology

\section{MEDICAL FINDINGS}

\section{Patient Participation:}

The participation of many excellent medical specialists undoubtedly has been a major factor in the acceptance of the Marshall Islands Medical Program by the population it serves, for utilization of the program is entirely voluntary. The percent of persons in the exposed and Comparison groups who appear for examination remains high. For the current reporting period the annual acceptance rates (corrected for nonavailability) were:

$\begin{array}{llllc} & \mathbf{1 9 8 8} & \mathbf{1 9 8 9} & \mathbf{1 9 9 0} & \mathbf{1 9 9 1} \\ \text { Rongelap } & 86 \% & 82 \% & 88 \% & 85 \% \\ \text { Utirik } & 84 \% & 91 \% & 85 \% & 87 \% \\ \text { Comparison } & 68 \% & 62 \% & 65 \% & 60 \%\end{array}$

The percent of the eligible population examined on at least one occasion during the last four-year period was:

$\begin{array}{ll}\text { Rongelap } & 95 \% \\ \text { Utirik } & 98 \% \\ \text { Comparison } & 90 \%\end{array}$

These figures do not include several persons residing outside the Marshall Islands. Most exposed persons in this category have medical examinations arranged through a local physician by the Department of Energy or the Marshall Islands Medical Program.

The acceptance rate for mammography among eligible women was $100 \%$. For sigmoidoscopy, about $75 \%$ of age-eligible persons elected to undergo this procedure on a regular basis.

\section{Overall Survival:}

After 37 years there continues to be little difference between the survival curves of either the high-exposure Rongelap group or the low exposure Utirik group and the age- and gender-matched unexposed Rongelap population selected in 1957 (Fig. 1). Estimates of the survival distribution by the actuarial life table method were analyzed by the Mantel-Cox and Breslow statistics for testing the equality of the survival curves. The " $\mathrm{p}$ " values for the two tests were 0.66 and 0.82 , respectively, for the Rongelap and Comparison group, and 0.43 and 
0.40 for the Utirik and Comparison group, indicating no statistically significant differences.

\section{Causes of Recent Mortality:}

The number of deaths occurring in 1988 through 1991 is as follows: Rongelap - 1: Utirik 3: expanded Comparison group - 10 (see p. 1 for the description of this group). The clinical events surrounding the deaths are described below.

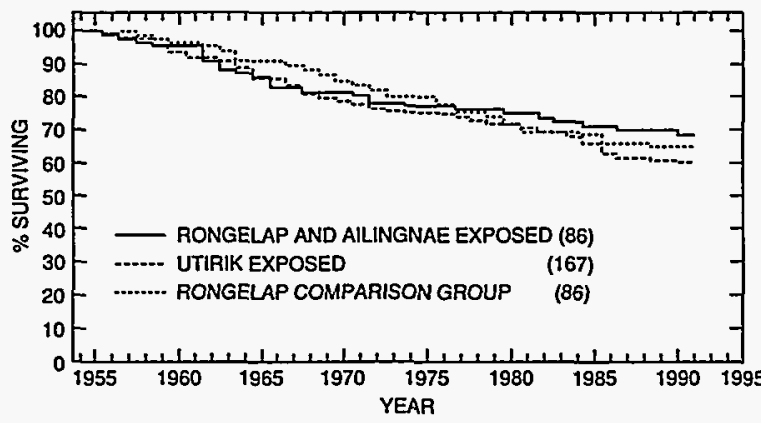

Fig. 1: Percent survivors of the different exposure groups since 1954. The number of persons initially in each group is shown in parentheses.

\section{Rongelap:}

Subject No. 1. Advanced complications of diabetes mellitus were the cause of death in December 1991 of this 58-year-old man. He had been referred to the Straub Clinic in Honolulu a month earlier for a scheduled colonoscopy because of a history of colonic adenomatous polyps. At that time no evidence of malignant disease was uncovered, and chronic renal failure was felt to explain the anemia, abnormal mental status, and neuropathy that had been developing in recent years.

\section{Utirik:}

Subject No. 2. The death certificate of this 54year-old woman lists "sepsis" and "diabetic gangrene/cellulitis (left) foot" as her cause of death in April 1991. She had diabetes mellitus with retinopathy and probably nephropathy, and she was last seen by the medical team in March 1990. At that time she had a guaiac-positive stool felt to be due to hemorrhoids. Her mammogram was "negative" and her Papanicolaou smear was normal. An alpha-fetoprotein level was normal (she was known to be hepatitis B surface antigenpositive), and a chest $x$-ray showed only pectus excavatum.

Subject No. 3. This 52-year-old man, a cigarette smoker, died in 1990; death certificate cause of death: malignant lymphoma with marked gastric involvement. When last seen by the Brookhaven medical team (April 1989) the patient had borderline hypertension requiring no therapy. No lymphadenopathy or splenomegaly was noted. $\mathrm{He}$ had symptoms consistent with esophageal reflux, for which he was given antacids. His blood count, urinalysis, stool guaiac and electrocardiogram were normal. A chest x-ray had been normal in 1988, and a flexible sigmoidoscopy was normal in 1987. His serum was known to be positive for hepatitis B surface antigen, but the alpha-fetoprotein level was normal in $1988(2.5 \mathrm{ng} / \mathrm{ml})$. The death certificate diagnosis was made on clinical grounds. No tissue diagnosis was possible. The patient died while departing Majuro to have an evaluation in Honolulu for his dysphagia and weight loss.

Subject No. 4. This 80 -year-old woman died on Utirik in 1988; in recent years she had become severely incapacitated with shortness of breath and arthritis of the shoulder. A medical team cardiologist diagnosed mitral regurgitation (secondary to ruptured chordae tendineae) and mild aortic stenosis/insufficiency. She was on digoxin and hydralazine for this. The joint problem, which was due to a shoulder injury at an early age and subsequent degenerative changes, was handled with acetaminophen. Her blood count when seen in March 1988 was normal except for a mild anemia (hemoglobin: $10.1 \mathrm{~g} / \mathrm{dl}$ ), present since 1984 (hemoglobin: $10.6 \mathrm{~g} / \mathrm{dl}$ ). Serum creatinine was normal in 1987, as was a Papanicolaou smear. Because of restricted mobility her medical exams were done in her home. She was unchanged clinically when last seen in September 1988. The cause of death is unknown.

\section{Comparison population:}

Subject No. 5. This 67-year-old man died on Ebeye in 1988. When last examined by the Brookhaven team (1985) his medical problems included marked obesity and chronic renal failure of 
unknown cause. There was no diabetes, and his urinary sediment showed red cells, casts and protein. The serum creatinine was $3.4 \mathrm{mg} / \mathrm{dl}$. He had chronic venous insufficiency in the legs and a left hydrocele. A serologic test for filaria was negative. There was also a mild macrocytosis; a serum B12 level was low normal. The cause of death is not known.

Subject No. 6. This 69-year-old man died on Ebeye in 1989. His medical problems in March 1988 included diabetes (status post leg amputation) with chronic renal failure, severe neuropathy, and eye infection from recent cataract extraction, for which he was referred. He was moderately anemic with a $\mathrm{Hb}$ of $9.6 \mathrm{~g} / \mathrm{dl}$. The cause of death is unknown.

Subject No. 7. This 42-year-old man died on Majuro in 1989. He had diabetes, extremely carious teeth, a cataract, and a disabling arthrogryposis. When last seen in 1989 his only medication was glyburide. His blood count and serum creatinine were normal. He was referred for cataract surgery. The death certificate lists overwhelming sepsis and severe pneumonia as the cause of death.

Subject No. 8. This 89-year-old woman died on Ebeye in 1990. No important medical problems were noted when patient was last seen in March 1988. She had severe kyphosis, cataracts, and perhaps a mild dementia, but in general annual examinations indicate she was usually in quite good health. Her blood count was normal and a Papanicolaou smear was Class $I$ in 1988. Medications included only acetaminophen and a skin antifungal agent. The cause of death is unknown.

Subject No. 9. This 76-year-old woman died on Ebeye on December 31, 1987. The death certificate diagnoses were cardiac failure and bronchitis. At the time of her last complete medical examination by the Brookhaven team she had a moderately severe anemia (hemoglobin level: $8.8 \mathrm{~g} / \mathrm{dl}$ ) and recent weight loss. The mean corpuscular volume was $98 \mathrm{fl}$. and there was some hypersegmentation. A serum B12 level was somewhat low $(170 \mathrm{pg} / \mathrm{ml})$, but the urine methylmalonic acid level was normal at $0.8 \mathrm{ug} / \mathrm{mg}$ creatinine. Nevertheless, she was started on intramuscular B12. Mammography was normal and her Papanicolaou smear was class I. When seen several months later in follow-up, she felt well. A flexible sigmoidoscopy was normal. It may be relevant that her husband had died recently, and it is possible that he had advanced tuberculosis.

Subject No. 10. This 59-year-old man died on Ebeye in 1990. He had advanced diabetes mellitus with nephropathy, retinopathy, and neuropathy. When last seen in March 1990 his creatinine was $12.4 \mathrm{mg} / \mathrm{dl}$ and the hemoglobin level was $10.4 \mathrm{~g} / \mathrm{dl}$. A HbA1c level was $6.8 \%$, only slightly elevated. Flexible sigmoidoscopy was negative in 1987, and a chest $\mathrm{x}$-ray at that time showed no active disease. He was being followed by the Diabetic Clinic on Ebeye. His death certificate listed renal failure due to diabetic nephropathy as the cause of death.

Subject No. 11. This 61-year-old man, a former heavy smoker, died on Majuro in 1989. He was known to have chronic renal insufficiency thought to be due to diabetes. He was referred in 1987 for evaluation of this problem. An ultrasound examination by the Brookhaven team revealed no calculi or hydronephrosis; renal size appeared normal. He had gout, and the renal disease could have represented uric acid nephropathy. There was a suggestion of pleural effusions on chest $x$-ray in 1988 when he was referred for further evaluation. When next seen by the medical team in March 1989 he had lost much weight and a hilar mass was noted on chest x-ray. He was referred for evaluation. Carcinoma of the lung was indicated on his death certificate.

Subject No. 12. This 73-year-old woman had breast cancer diagnosed in 1985 after a breast nodule was detected during her annual medical program physical examination. A mastectomy was done that year. She died in 1991. When last seen by the medical team (March 1989) there was no evidence of metastatic disease, and the cause of death is unknown.

Subject No. 13. This 64-year-old woman died on Ebeye in 1988. Her last complete Brookhaven examination was in 1986, when her problems included insulin-dependent diabetes mellitus, urinary tract infection, and abnormal liver function tests. When repeated, the latter showed only a minimally 
elevated alkaline phosphatase. A flexible sigmoidoscopy and mammography were negative, blood count was normal, and Papanicolaou smear was class I. She had carcinoma of the endometrium in 1979 which was effectively treated by total abdominal hysterectomy. Septicemia and nonketotic hyperosmolar diabetic coma were listed on her death certificate as the causes of death.

Subject No. 14. This 54-year-old woman died on Ebeye in 1990. When last seen by the Brookhaven team in October 1989 she was taking glyburide for diabetes mellitus and had a fasting glucose of $208 \mathrm{mg} / \mathrm{dl}$ and a $\mathrm{HbA1c}$ level of $7.4 \%$ (mildly elevated). A blood count was normal. Other problems considered earlier were bilateral cataracts, fibrocystic disease of breasts with negative mammogram in May 1989, negative Papanicolaou smear in 1988, and normal flexible sigmoidoscopy in 1987. The cause of death is unknown.

\section{Laboratory Findings:}

\section{Hematology}

A review of "blood counts" (average concentrations of formed blood elements) of the different exposure groups during the four-year reporting period does not reveal any systematic differences among groups. In 1989 and 1990 there was a significant increase in mean platelet count in Utirik exposed women as compared to the unexposed population (Table I). Figure 2 is a continuation graph in which hematologic data of the two exposed groups collected since 1956 are portrayed in relation to the expanded Comparison group. Table I gives the mean values $(+/-S D)$ from which Fig. 2 is derived. The individual counts are given in Appendix B.

It is apparent from scanning the four graphs in Fig. 2 that there is a mild but relatively consistent depression, generally not statistically significant different, over most of the 37 post-exposure years, of neutrophil, lymphocyte, and platelet concentrations (the latter in males only) in the Rongelap/Ailingnae group. This depression appears to be of no clinical significance. These consistently slightly lower values for all three formed blood elements over such a long period in the Rongelap group suggests the possibility of radiation related mild impairment of hematopoiesis. However, there is no evidence of impaired leukocytosis in response to infection. Therefore, these differences may reflect a shift in cell compartmentalization (e.g. margination).

Hematologic changes in Japanese atomic bomb survivors have been recently reviewed (Finch and Finch, 1988). An early decline in leukocyte counts was detected from 1947 through 1956, but this occurred in both exposed and unexposed groups, and therefore was not an effect of radiation. Indeed, "no clearly established exposure differences have been uncovered except in the case of the leukemias" (Blaisdell and Amamoto, 1966). Therefore, a sustained depression in leukocyte counts, such as seen in the Rongelap group, was not detected among the exposed Japanese. With regard to leukocyte margination, no evidence of a radiation dose-effect in the exposed Japanese was apparent when exercise-induced leukocytosis was quantified (Belsky et al., 1972).

In general, radiation has been found to alter leukocyte function in humans only minimally, if at all, and, when dysfunction has been detected, it has been of no clinical importance. The most recent clinical study to confirm this was carried out on Japanese atomic bomb survivors and included phagocytic and bactericidal activities of neutrophils (Sasagawa et al., 1990).

It was noted that for ten years after the atomic bombings in Japan the leukocyte counts of persons followed by the Atomic Bomb Casualty Commission gradually decreased by about $35 \%$ in both the exposed and unexposed populations (Blaisdell and Amamoto, 1966). This trend was never completely explained, but the decline was chiefly attributable to a decrease in neutrophils. A slight trend in this direction can be detected in total leukocyte counts obtained on the Marshallese over a similar time span. Using data from the unexposed Comparison group, the mean total leukocyte concentration for 1954-1958 was 8,500/ul and for 1969-1974 it was 7,300/ul, a 14\% decline. For 1985-1990 it has been $7,500 /$ ul. A decrease in absolute lymphocyte concentration, approximately 1,000/ul, occurred simultaneously. This finding differs from that of the Japanese, in whom it was the neutrophils that were predominantly lowered. For the Marshallese, minimal fluctuation was seen in neutrophil count for the three periods. The reason for the apparent decrease in lymphocyte concentration in both exposed and unexposed Marshallese is unknown. 
NEUTROPHILS

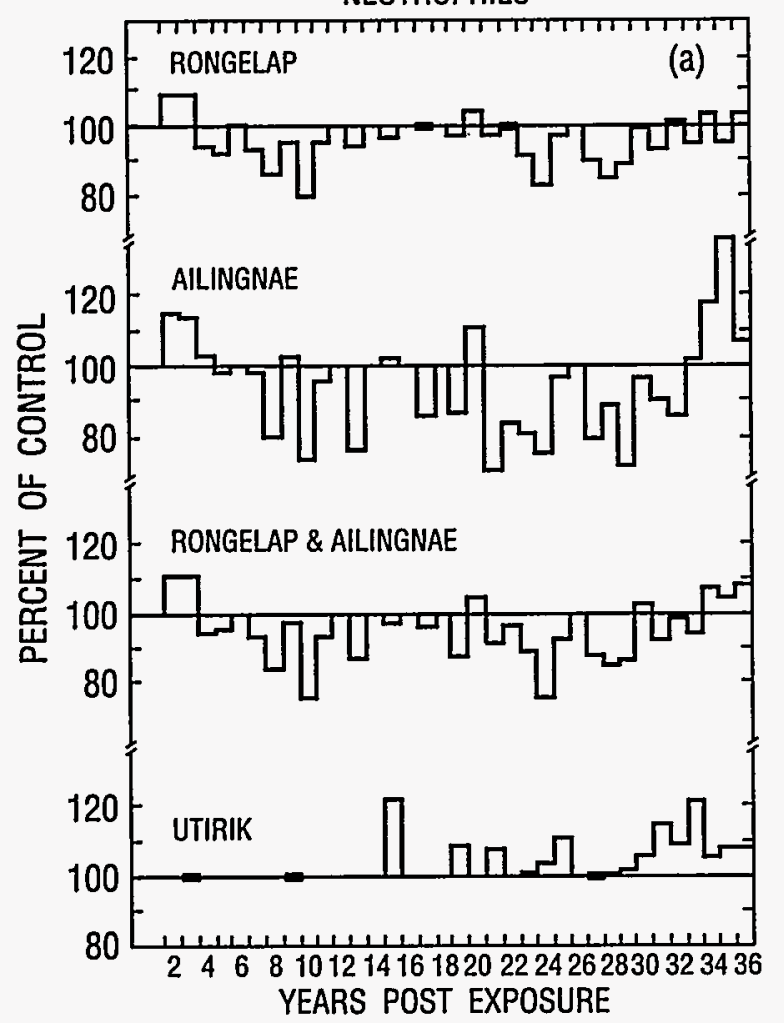

PLATELETS - MALES

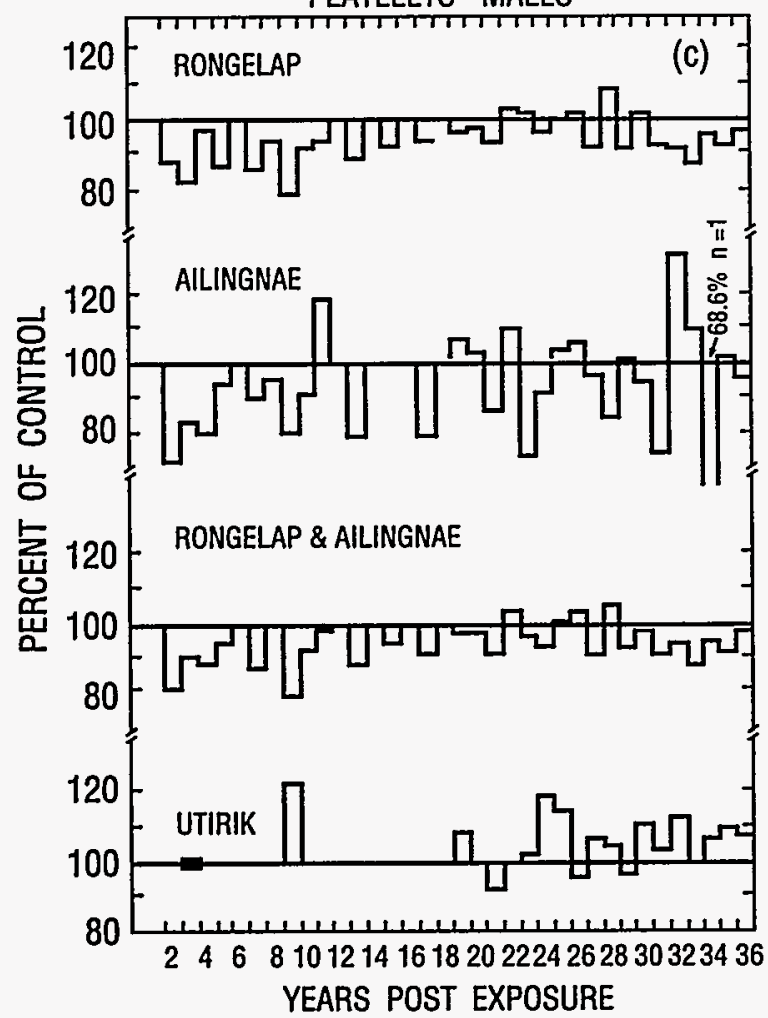

LYMPHOCYTES

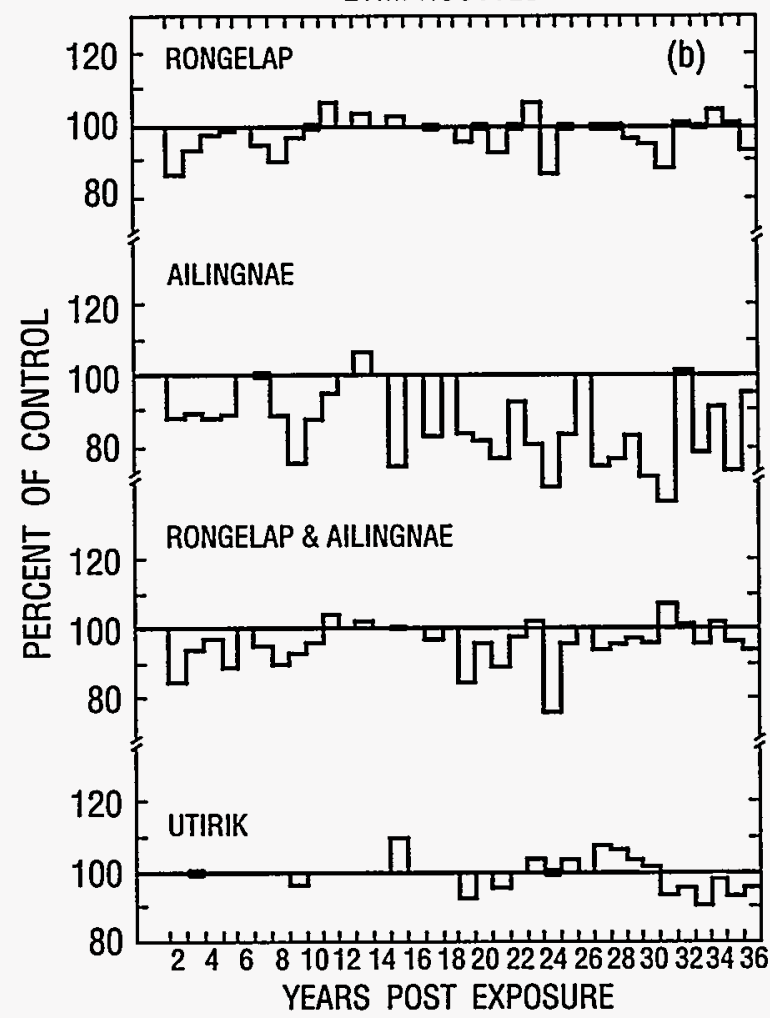

PLATELETS - FEMALE

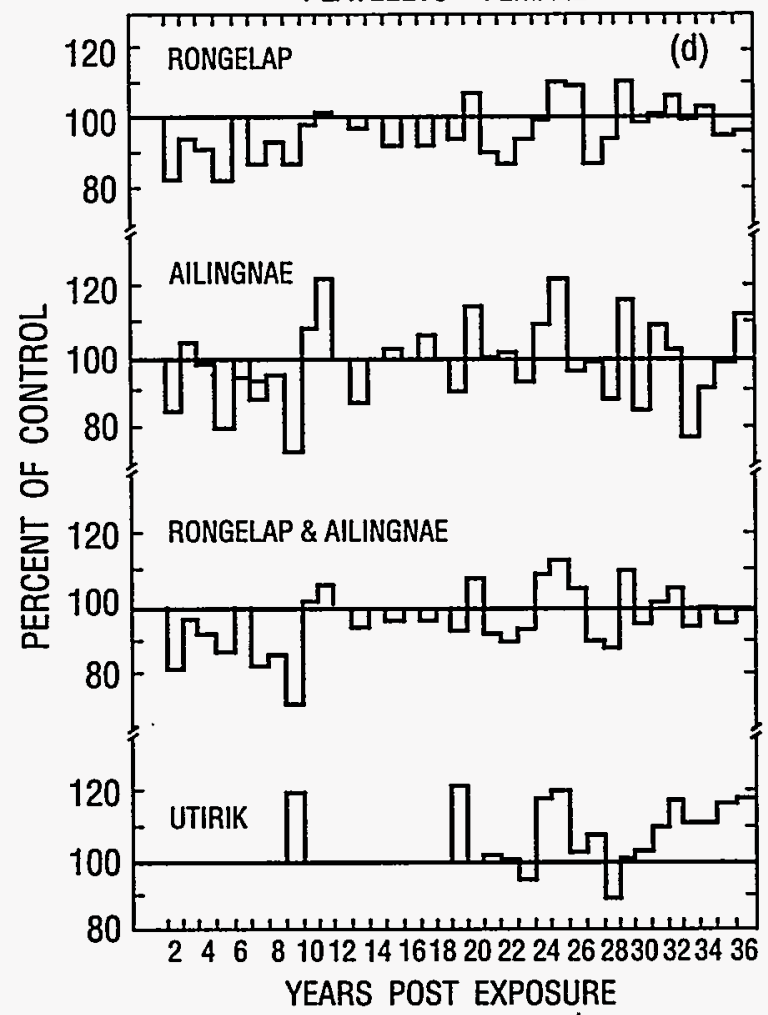

Fig. 2. Annual mean blood cell counts of the different exposure groups (age 5 years or more) expressed as percent of the unexposed Comparison group, beginning two years after exposure. Values for both sexes are grouped for neutrophils and lymphocytes. Detailed annual observations, including blood cell counts, on the Utirik population did not begin until 1973. Leukocyte differentials and platelet counts were not obtained for six and five of the examination years, respectively, but for graphing purposes the $100 \%$ line has not been broken at those years. 
TABLE 1: Hematologic parameters (mean +/- SD) for the different exposure groups. obtained at the time of annual examination for years 1988 through 1991.

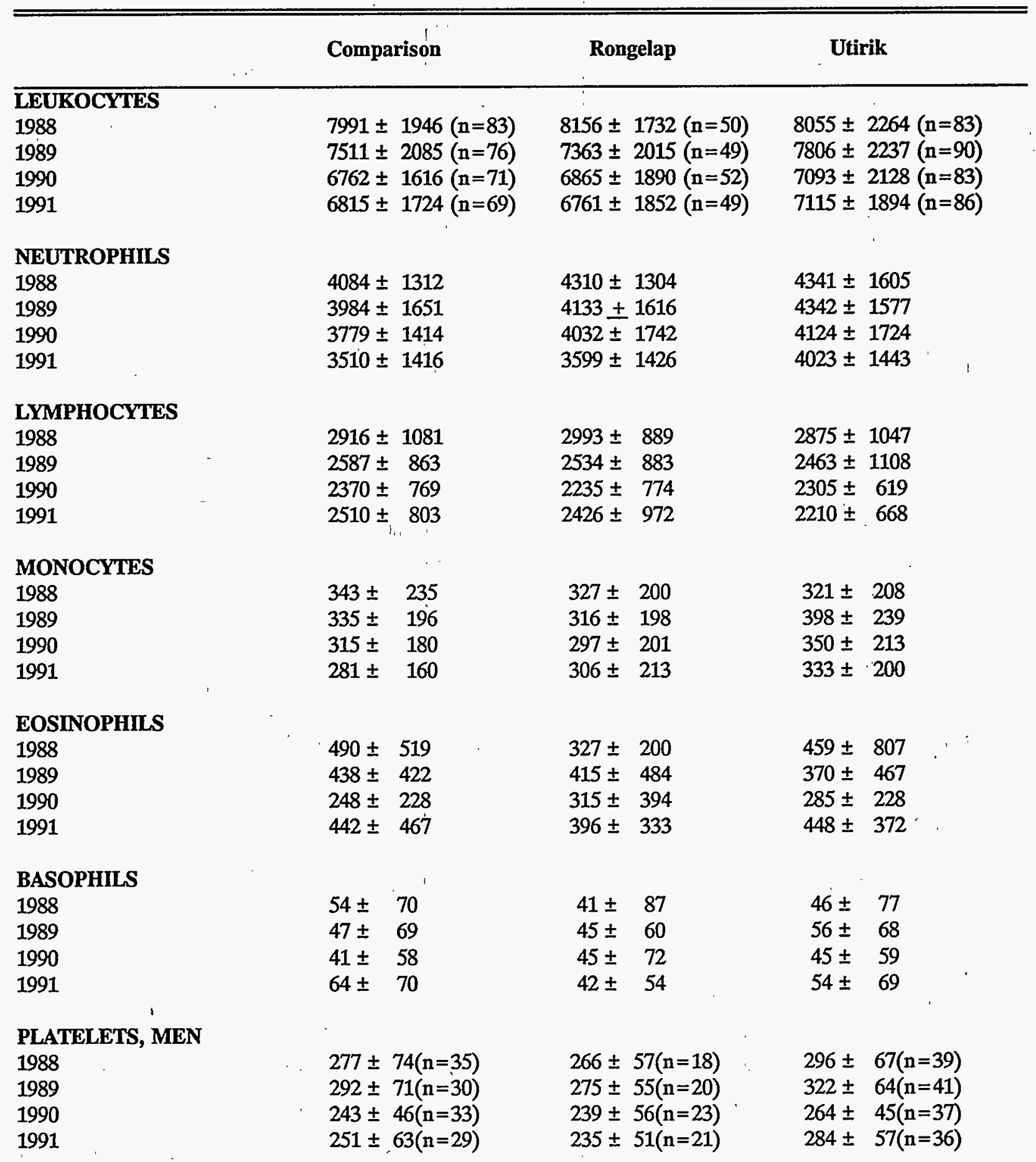


TABLE 1 (cont'd)

\begin{tabular}{llll} 
PLATELETS, WOMEN & & & \\
1988 & $318 \pm 84(\mathrm{n}=47)$ & $319 \pm 87(\mathrm{n}=28)$ & $356 \pm 100(\mathrm{n}=44)$ \\
1989 & $312 \pm 68(\mathrm{n}=45)$ & $300 \pm 71(\mathrm{n}=28)$ & $352 \pm 83(\mathrm{n}=47)^{*}$ \\
1990 & $272 \pm 44(\mathrm{n}=44)$ & $272 \pm 55(\mathrm{n}=29)$ & $322 \pm 58(\mathrm{n}=46)^{*}$ \\
1991 & $280 \pm 55(\mathrm{n}=39)$ & $296 \pm 71(\mathrm{n}=27)$ & $336 \pm 79(\mathrm{n}=46)$ \\
HEMOGLOBIN, MEN & & & \\
1988 & $15.1 \pm 1.2$ & $14.6 \pm 1.1$ & $15.1 \pm 1.2$ \\
1989 & $14.7 \pm 1.6$ & $14.3 \pm 1.3$ & $15.3 \pm 1.4$ \\
1990 & $14.8 \pm 1.5$ & $14.0 \pm 1.4$ & $15.4 \pm 1.4$ \\
1991 & $14.9 \pm 1.3$ & $14.3 \pm 1.3$ & $15.4 \pm 1.6$ \\
& & & \\
HEMOGLOBIN, WOMEN & & $13.2 \pm 1.0$ & $12.9 \pm 1.3$ \\
1988 & $13.4 \pm 1.0$ & $13.3 \pm 0.9$ & $13.0 \pm 1.3$ \\
1989 & $13.4 \pm 1.0$ & $13.1 \pm 1.1$ & $12.9 \pm 1.3$ \\
1990 & $13.2 \pm 1.0$ & $12.8 \pm 1.4$ & $12.8 \pm 1.2$ \\
1991 & $13.0 \pm 1.0$ & & \\
\hline \hline
\end{tabular}

* Significantly different $(\mathrm{p}<0.05)$ from the Comparison Group

\section{Hypothyroidism:}

Thyroid hypofunction, either clinical or biochemical, has been documented as a consequence of radiation exposure in fourteen Rongelap individuals (Larsen et al., 1982). In 1983 another exposed person was diagnosed as being biochemically hypothyroid based on results of routine thyroid function testing (Adams et al., 1988). The patient was an asymptomatic 34 -yearold man who had no abnormality on physical examination of the thyroid. Treatment with synthroid was started in 1984. This represented the first case of spontaneous hypothyroidism diagnosed in the Utirik population. He was 1 year of age at the time of exposure, and, being from Utirik, no thyroxine suppression had been subsequently prescribed. An estimate of his total thyroid radiation dose was $561 \mathrm{cGy}$ (internal = $550 \mathrm{cGy}$; external = $11 \mathrm{cGy}$ ). Clinical follow-up of this patient since 1987 has revealed the following. At the patient's request thyroid function tests were repeated by physicians of the Health Services of the Marshall Islands while he presumably was not taking thyroxine. However, we do not know the assay methodology or whether the patient in fact, discontinued his thyroxine. The results were found to be normal.

The conclusion of those physicians was that he was euthyroid and that the decrease in thyroid function noted by the Brookhaven medical program represented self-limited hypothyroidism due to thyroiditis. However, there was no evidence of a preceding hyperthyroid state.

Furthermore, his thyroid function studies over the years were:

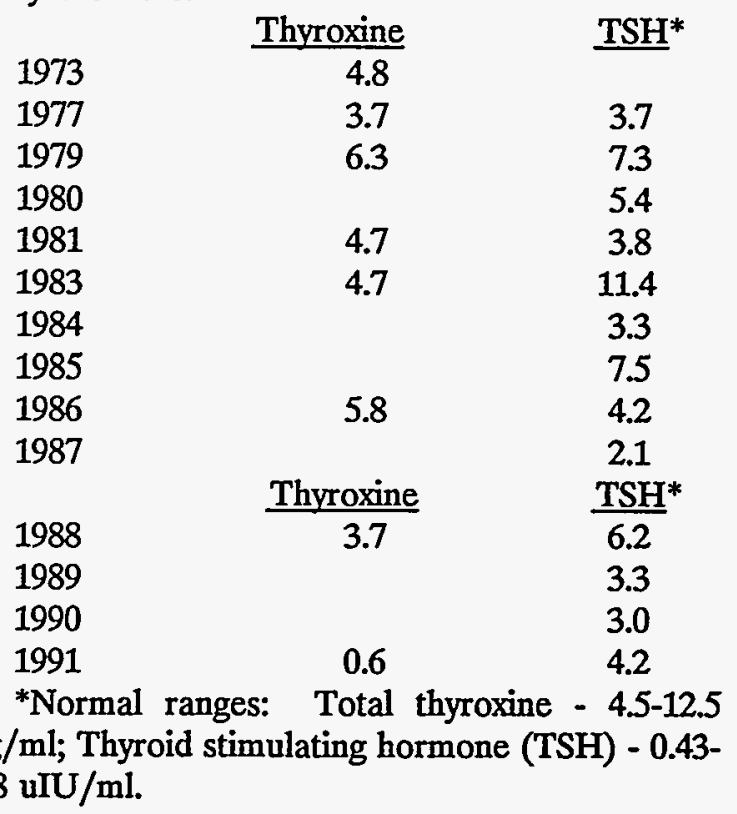


Thus, this patient's thyroid function tests have been on the low side of normal and occasionally overtly low for many years. Transient hypothyroidism persisting for many years has been reported with chronic autoimmune thyroiditis (Takasu et al., 1992). However, the Utirik patient had no detectable antithyroglobulin or antimicrosomal antibodies. While the role of radiation exposure in producing this patient's illness is not certain, an argument can be made for relating the two. Further observation may document the true nature of the thyroid hormone fluctuations in this patient. Since an increase in risk of hypothyroidism might be attributed to radiation exposures as low as $20 \mathrm{cGy}$ (Maxon et al., 1977), the patient clearly was at risk for developing the disorder.

\section{Other laboratory results:}

Appendix B also includes results of other tests that are performed on many or all of the exposed persons. Several of these tests have been used to screen for occult malignant disease. Although there is no general marker for malignancy, the clinical justification for, and the results of, those tests are described here.

\section{Serum protein electrophoresis}

Multiple myeloma is one of the hematological malignancies that has been determined to be inducible by radiation (Cuzick, 1981). This interpretation is strengthened by findings in Japanese atomic bomb survivors, although the effect of radiation was not detectable until about 20 years after exposure (Ichimaru et al., 1982). The production of a monoclonal protein detectable by serum electrophoresis often precedes by years the other clinical manifestations of multiple myeloma. Although the risk of myeloma is small, serum protein electrophoresis is performed on the exposed Marshallese about every three years in order to detect the early appearance of a monoclonal protein. If a monoclonal spike were to be found in a patient's serum, it would not necessarily indicate the presence of myeloma. Conversely, the absence of such a spike does not rule out myeloma. Nevertheless, it is used as a screening test, and no monoclonal proteins were detected during the 1989 serum testing of the Marshallese sera.
In common with many populations in tropical regions, the Marshallese have relatively high globulin levels. This increase is polyclonal, and the cause is unknown.

\section{Serum calcium}

An endocrinological disorder that has been thought to be associated with both external and internal ${ }^{131}$ I radiation is hyperparathyroidism (Cohen, et al., 1990; Rosen et al., 1984). A dosedependent increase in the incidence of hyperparathyroidism has also been reported in Japanese atomic bomb survivors (Fujiwara et al., 1990). In all three cited studies, parathyroid adenomas were present in most patients. Some of the exposed Marshallese received large radiation doses to the parathyroid gland, as well as high external doses. Furthermore, the susceptibility of Marshallese to this effect of radiation is unknown. Therefore, serum calcium levels are checked every three years. No elevated levels were detected during the 1989 survey.

\section{Serum alpha-fetoprotein}

There is a high risk of hepatocellular carcinoma in persons who remain persistently positive for hepatitis B surface antigen. The last Brookhaven medical program report discussed this disease in relation to the exposed Marshallese, for the prevalence of serologic evidence of hepatitis B infection in the Marshall Islands is very high (Adams et al., 1986). In some instances it is possible to identify hepatocellular carcinoma at an early stage by testing serum for alpha-fetoprotein. This might permit identification of the tumor at a stage when it is still resectable. Therefore, all exposed and unexposed persons who are known to the medical program to be seropositive for hepatitis B surface antigen have alpha-fetoprotein levels performed annually.

\section{Erythrocyte macrocytosis}

The many causes of macrocytosis include several premalignant and malignant hematologic diseases. Therefore, erythrocyte size is checked annually. During the four years covered by this report no unexplained or irreversible macrocytosis was detected in the exposed population. Those elevated levels that were found appear to have been due to nutritional deficiencies (either folic acid or vitamin B12) or chronically excessive ingestion of alcohol. 
Serum prolactin

Two pituitary tumors have been identified in the exposed Marshallese (Adams et al., 1984). Because other exposed persons might develop these benign neoplastic lesions, prolactin levels are performed every two years. Although serum prolactin elevation is not found in all pituitary tumors, it is by far the most common hormonal abnormality and therefore is used as the screening test for the exposed population. No new or unexplained elevations were detected for the present reporting period, but one elderly Utirik woman still has the slightly elevated level mentioned in a previous Brookhaven report (Adams et al., 1985). A CT scan of the patient's sella turcica in 1990 revealed no tumor.

\section{Neoplasms:}

\section{Skin cancers}

One basal cell carcinoma of the face was diagnosed in an exposed Rongelap woman in 1986 (Adams et al., 1988). A second person, also in the Rongelap exposed group, had a basal cell carcinoma removed in 1991. The development of two skin cancers some thirty years post-exposure in a population not considered susceptible to such lesions raises the possibility that there is some relation to their 1954 beta radiation exposure. The specific clinical situations are described below.

Subject No. 1. This 56-year-old Rongelap man was 18 years of age at the time of his exposure to fallout from BRAVO. He washed off the debris within several hours after the fallout ceased. He sustained first-degree burns to his right antecubital fossa and both feet. These became apparent several weeks after exposure and lasted for several weeks. $\mathrm{He}$ also experienced typical nail discoloration. One year later on reexamination healing was complete. Subsequent skin examinations were unremarkable until April 1991 when a $1.5 \mathrm{~cm}$ lesion with a necrotic center was noted on his left scapula. An excisional biopsy was performed and the final pathological diagnosis was basal cell carcinoma. The tumor extended to all lines of excision. Therefore, definitive treatment consisted of a reexcision a few months later. Subsequent examinations have revealed no evidence of recurrence.
Subject No. 2. This 70-year-old Rongelap woman was 38 years of age at the time of exposure. She was felt to be one of two patients most heavily exposed to external beta radiation. She did not wash off the fallout debris for a full 24 hours. Within a few days skin lesions developed. The burns, most first degree, eventually included the neck, neckline, left hand and wrist, left cheek, forehead, thorax and groin, lasting another few weeks. There was some hair loss. One year later the skin had essentially healed, except that there was persistent beta-burn scarring on the left side of the neck noted up to 1960 . Followup skin examinations were benign until April 1986 when two skin lesions were noted: a $4 \mathrm{~mm}$ papule in the right supraorbital area and a $7 \mathrm{~mm}$ nodule anterior to the right ear. Excisional biopsies revealed both to be basal cell carcinomas. Reexamination up to 1992 has revealed no evidence of recurrence.

Skin cancer in dark-skinned races has generally been considered to be rare. Studies in a black population suggest that skin cancer occurs at the site of old burns or other scars, chronic ulceration and infection (Oettlé, A.G.; Databo-Brown, D.D.; and Fleming I.D. et al.). These cancers are usually squamous cell carcinomas and are invasive and aggressive (Amonette, R.A. and Kaplan, K.J., and Fleming I.D. et al.). Basal cell carcinomas, when they do occur, are located in sun-exposed areas, as they are in Caucasians. That there is a relative increase in incidence of skin cancer in black albinos or those of mixed race when compared to pure Blacks (Oettlé, A.G. and Burns, J.E.) suggests that melanin is a protective factor. Other ethnic groups have not been extensively studied.

Ionizing radiation from sources other than sunlight is also known to be a risk factor in the induction of skin cancer (Davis, M.M., et al; Walther, R.R. et al.; and Myskowski, P.L. et al.). Studies of children irradiated for ringworm (Shore, R.E., et al.; and Ron, E., et al.) and other patients irradiated for a variety of conditions (Davis, $M$. et al.; Walther, R. et al.; and Myskowski, P. et al.) show that radiation is associated with an increased incidence of skin cancer, mostly basal cell tumors, and generally occurring among Caucasians, but occasionally in Blacks.

The skin cancer in the Rongelap woman (\#2) occurred in an area that was both sun-exposed and previously injured by beta radiation. For the Rongelap man (\#1) neither sun nor beta radiation would have been expected to converge on the 
subscapular area (unless he had been customárily shirtless). However, two persons developing skin cancer out of a radiation-exposed population of 82 (2.5\%) is greater than expected if Black population studies are used for comparison (Fleming, I.D. et al.). Furthermore, there is a suggestion of a temporal association, for the cancers occurred 32 and 37 years after exposure. Therefore, the possibility remains that radiation exposure did contribute in a direct or indirect way to the development of basal cell carcinomas in these two patients.

\section{Thyroid nodules}

Only one thyroid nodule was diagnosed in the exposed population from January 1988 through December 1991. That nodule occurred in a Utirik man who had been in utero at the time of exposure in 1954. The mother was in her third trimester at the time of exposure, her whole-body and thyroid-absorbed doses being estimated at 11 and $160 \mathrm{cGy}$, respectively. The patient's estimated dose was, therefore, $11 \mathrm{cGy}$ whole-body and 99 cGy internally to the thyroid, for a total thyroid dose of $110 \mathrm{cGy}$. This patient is the first of eight Utirik persons exposed in utero to develop a thyroid nodule. (Two of four Rongelap persons who were in utero at the time of exposure have also had benign nodules removed). A thyroid lobectomy was performed at the Clinical Center, The National Institutes of Health. Histological review of the surgical material was performed by the four pathology consultants to the Marshall Islands Medical Program (see p. 16). Selected comments from their diagnoses are:

Consultant \#1 - "Thyroid nodule of histologically normal tissue which contains a tiny focus of occult papillary carcinoma."

Consultant \#2 - "Adenomatous goiter in the colloid stage."

Consultant \#3 - "Nodule with fibrosis.... No evidence of cancer."

Consultant \#4 - "Tiny occult sclerosing papillary carcinoma."

A summary of this patient's hospital case is included in Appendix C. The patient was returned home on thyroxine suppression.
Table 2 summarizes the thyroid nodule findings in the exposed Marshallese through 1991. It includes the nodule described in the preceding paragraph, which is listed under the heading of "Occult Papillary Carcinoma." The number and types of nodules in the Comparison group are also listed in Table 2, although the U.S. Department of Energy-sponsored program for surgical exploration of palpated nodules in this group was concluded in 1985.

\section{THYROID SURGERY FINDINGS, 1964 THROUGH 1991}

\section{Introduction:}

Thyroid nodules and hypofunction among the exposed populations of Rongelap and, to a lesser extent, Utirik are well documented consequences of the BRAVO exposure. A recent reevaluation of external and internal radiation exposures in those populations in all likelihood represents the definitive quantitative analysis of organ and whole-body radiation dose stemming from this catastrophe (Lessard et al., 1985). The thyroid dose received particularly close scrutiny because of early evidence of extensive thyroid injury and because an important mechanism of exposure was ingestion of a variety of radioiodines, an occurrence without precedent and therefore with unknown consequences.

A final interpretation of the effect of fallout exposure on the thyroids of the exposed Marshallese has not been possible because of the protracted evolution of thyroid abnormalities following radiation exposure. The incidence of thyroid cancer has been reported to be elevated more than 40 years after radiation exposure (Shore et al., 1985; Schneider et al., 1978) and might include a lifetime at risk. However, for the past six years (1986 through 1991) only one new thyroid nodule (nonmalignant) has been detected in the exposed persons. Furthermore, there has been only one new nodule diagnosed in the Rongelap group in the past ten years. (There have been two thyroid surgeries for recurrent benign nodules in the Rongelap group, but these are not included in the statistics that follow). Although occasional nodules will no doubt continue to be diagnosed, if for no other reason than that thyroid nodule prevalence increases naturally with aging, it is possible that the recent dearth of cases represents a pause that is 
TABLE 2: Thyroid Nodules Diagnosed at Surgery through 1991

\begin{tabular}{lccccc}
\hline \hline & $\begin{array}{l}\text { Adenomatous } \\
\text { nodules }\end{array}$ & Adenomas & $\begin{array}{l}\text { Papillary } \\
\text { cancers }\end{array}$ & $\begin{array}{l}\text { Follicular } \\
\text { cancers }\end{array}$ & $\begin{array}{l}\text { Occult } \\
\text { cancers }\end{array}$ \\
\hline Rongelap (67) & 18 & 1 & 5 & - & - \\
Ailingnae (19) & 4 & 1 & - & - & 1 \\
Utirik (167) & 10 & 5 & 4 & $1^{\text {c }}$ & 6 \\
Comparison (277) & 4 & 1 & 2 & - & $2^{\text {d }}$ \\
\hline \hline
\end{tabular}

NOT INCLUDED are the following unoperated (and therefore unconfirmed) nodules: Rongelap--1: Ailingnae - 1: Utirik -- 1: Comparison -- 5.

INCLUDED are all consensus diagnoses of a panel of consultant pathologists: two different lesions were detected in one person from Rongelap, one from Ailingnae, and two from Utirik.

a Number of persons (including those in utero) who were originally exposed.

b This number includes all persons who have been in the Comparison group since 1957. Some have not been seen for many years; others were added as recently as 1976 . No thyroid surgeries have been performed on this group since 1985.

c Equally divided opinion in one case; follicular carcinoma vs. atypical adenoma.

d. Majority opinion in one case; occult papillary carcinoma vs. follicular carcinoma. The same patient had lymphocytic thyroiditis.

characteristic of the type of thyroid injury sustained by the Marshallese. Two alternative explanations are 1) the "epidemic" of thyroid nodule formation is virtually over, and 2) the recent decrease in nodule incidence is due to random fluctuation and therefore temporary. Although time may tell which of the above explanations is correct, the respite in new cases provides an opportunity to bring together information on thyroid nodules collected by the Marshall Islands Medical Program over almost three decades and to draw tentative conclusions on several issues that may be relevant to inadvertent radiation exposures elsewhere.

\section{Radiation risks to the thyroid:}

One aspect of radiation-induced thyroid injury that has been repeatedly assessed is the dose of radiation required to induce it. Data available from the Marshall Islands Medical Program have been recently summarized (Robbins and Adams, 1988), with the following conclusions:
1) The risk coefficient for thyroid nodules, adjusted for their occurrence in the Comparison population, was 8.3 per $10^{6}$ persons, per cGy, per year.

2) The risk coefficient for thyroid cancer was 1.5 per $10^{6}$ persons, per cGy, per year.

3) The contribution of ${ }^{131}$ I to the thyroid absorbed dose was relatively small, in the range of 10 $15 \%$, the remainder being due to short-lived radioiodines. Perhaps as a consequence, the radiation-induced risk for developing nodular disease in the exposed Marshallese appears similar to that predicted if the total thyroid dose had been from external irradiation alone.

Since the above analysis included all the nodules up to the present, and since the Marshallese thyroid dose data have provided no insight into radiationinduced risk of thyroid carcinoma that was not already available from other sources, no further comment on dose-response and risk of thyroid disease will be made in this summary. 
Histologic definitions:

In interpreting the Brookhaven medical program data on thyroid nodules the histopathological classification of thyroid nodules used by the expert panel of pathologists needs to be reviewed. This classification, based on diagnostic categories recommended by the World Health Organization (Hedinger and Sobin, 1974) and modified in 1981 by Dr. Donald Paglia of the Department of Surgical Pathology, University of California, Los Angeles, for the panel's use, has been applied to all thyroid specimens obtained at surgery since the beginning of the program:

Adenomatous nodule: a focal proliferative lesion consisting of changes typical of adenomatous goiter; the lesions are hyperplastic and do not fulfill criteria of true neoplasms.

Adenoma: an encapsulated proliferative lesion with a uniform internal growth pattern and benign clinical course.

Occult papillary carcinoma: a small nonencapsulated sclerosing carcinoma; considered to be clinically benign even if associated with positive regional lymph nodes.

Papillary carcinoma: larger, infiltrating carcinoma, usually containing both papillary and follicular components.

The four pathologists on the panel that review the Marshallese specimens are: Dr. L.V. Ackerman, Health Sciences Center, SUNY, Stony Brook, NY; Dr. W.A. Meissner, formerly with New England Deaconess Hospital, Boston, MA; Dr. A.L. Vickery, Massachusetts General Hospital, Boston, MA; Dr. L.B. Woolner, Mayo Clinic, Rochester MN. Histologic sections of all surgically removed thyroid tissue have been examined by these authorities. Although most diagnoses have been unanimous, some were controversial. In the following analysis and discussion of Marshallese nodules, the "most neoplastic" diagnosis has been selected when there has been a split decision, with the "least neoplastic" being the adenomatous nodule, next being the adenoma, the third being occult papillary cancer, and the most neoplastic being the carcinoma.
Appendix D lists all exposed persons who have had thyroid surgery which confirmed a thyroid lesion.

Thyroid nodules in the Comparison group:

The examination of the Comparison group has been invaluable in interpreting the thyroid nodule risk data among the exposed population. Even though they do not constitute an ideal "control" group, it is not likely that a better comparison population could have been obtained without initiating a formal, prospective research effort. It is appropriate that the voluntary cooperation of the members of this group be gratefully acknowledged by all who have relied on the Marshallese thyroid nodule data to interpret the role of radiation in causing thyroid disease. In that the unexposed Comparison group comprises persons of Rongelap ancestry and was quite closely age- and gendermatched when selected in 1957, this group is more representative of the exposed Rongelap population than any other Marshallese community and certainly more so than a population of non-Marshallese.

The development of thyroid nodules in the Comparison population is similar to the spontaneous thyroid nodule incidence reported elsewhere. Maxon et al. (1977) concluded that the rate of development of benign thyroid nodules and thyroid carcinomas in western countries is $0.07 \%$ and $0.01 \%$ of the population per year, respectively, and that the incidence is linear with respect to age. In 1990 the number of person-years of observation of the Comparison group was 10,400 . Therefore, based on the conclusions of Maxon et al. (1977), the expected number of thyroid nodules, benign and malignant, would be 8.3 , of which 6 or 7 would be benign and 1 or 2 would be carcinomas. ${ }^{*}$ In fact, 8 nodular thyroids were detected, of which 6 were benign and 2 were carcinomas (see Table 2). Possible sources of inaccuracy include the following: (1) Only surgically confirmed nodules are included. Therefore, since several unoperated nodules have been diagnosed in the Comparison group, the "observed" number may underestimate the true number of thyroid nodules. However, the palpated nodules may have been lipomas or neuromas, for example, and therefore appropriately excluded. (2) One of the two occult papillary carcinomas diagnosed in this group was not detected prior to surgery. This "nodule" is therefore excluded. Thus the total number of nodules is given as 8 rather than 9, as listed in Table 2. (3) 1984 is the latest 
year of observation for the purpose of this calculation because thyroid surgery for the Comparison group was not offered after 1985.

*In this calculation, to obtain the number of person-years of observation the individual ages at the time of the most recent examination were summed, with the exclusion of all years subsequent to thyroid nodule surgery in those cases where it was performed. To use an extreme example, if a 60 year-old person was first enrolled in the Comparison group and examined in 1975 and subsequently never appeared for reexamination, 60 person-years of observation was calculated. The justification for this approach is that it is considered unlikely that any clinically apparent thyroid nodule will spontaneously disappear. In a recent follow-up study of children among whom some nodules had been detected approximately fifteen years previously, only 10 percent of the nodules were no longer palpable (Rallison et al., 1991).

Factors influencing data interpretation:

It is possible to draw tentative conclusions relevant to issues of radiation injury to the thyroid from data available on the exposed populations alone, thereby avoiding assumptions about the adequacy of a control group. The data underlying the following analyses are shown in Appendix D and grouped and tabulated in Table 3. However, interpretation of the Marshallese thyroid nodule data must be done cautiously because of the small number of observations that were possible. This is particularly true when the nodules are subgrouped and analyzed by histologic type. In addition, thyroid disease is greatly influenced by gender, thereby further decreasing sample size for some analyses, particularly in males. Another confounding factor, thyroxine suppression, was initiated in 1965 in an attempt to inhibit or prevent the growth of benign and malignant thyroid nodules. This was prescribed only for the exposed Rongelap population, for the risk of nodule development resulting from the much lower Utirik exposure was felt to be small at that time. It therefore becomes difficult in some instances to interpret results in which Rongelap and Utirik data are grouped together. Finally, just why there were no nodules detected during the first nine years of medical team visits (1955-1963) is not clear. Based on the estimate of nodule incidence of Maxon et al. (1977) two nodules would have been expected to develop in the Rongelap group by 1963 . It is possible, therefore, that the absence of nodules in the early years was merely a consequence of random distribution of a relatively uncommon abnormality, particularly since the mean age of the Rongelap people at the time of exposure was rather low, 27.6 years. Once the first nodules were detected in 1963 it became the procedure of the Marshall Islands Medical Program to include in its medical team a person highly skilled in thyroid examination, usually an endocrinologist with special expertise in thyroid disease or a thyroid surgeon. This change in procedure introduces a possible bias that is impossible to quantitate.

It is possible that some nodules in the exposed population were naturally occurring rather than radiation-induced. However, as there is no way to identify which nodules these were, no attempt has been made to correct for their presence.

Issues that can be addressed without invoking data . from the Comparison group:

1) Is the "epidemic" of thyroid nodules over?

The number of patients undergoing thyroid surgery by year over the duration of the Marshall Islands Medical Program is shown in Fig. 3a. The same data are shown in Fig. 3b except that cases are expressed as percent of the population that remained susceptible to new nodule formation; i.e., excluding persons with prior nodules and persons who had died prior to the year for which a percent was calculated. Clearly the incidence of nodules which began in the mid-1960's in the exposed Rongelap group has greatly, if not completely, subsided. Their detection spanned 22 years, beginning 9 years after exposure. The nodules in the Utirik group, on the other hand, had a later onset and a later apparent decline. Detection of Utirik nodules has spanned 19 years, beginning 15 years after exposure.

In the following discussion the total thyroid absorbed dose in Figures 4-7 represents the acute radiation dose to the thyroid occurring during exposure to fallout prior to evacuation and time to development of nodules (years post exposure) refers to the interval in years from exposure to the initial clinical detection of the nodule.

Possibly more appropriate questions to ask are, (1) is the epidemic of adenomatous (nonneoplastic) nodules over, and (2) is the epidemic of neoplastic 
Table 3: Major thyroid nodules types*, total (internal and external) mean thyroid-absorbed dose, and time from exposure (1954) to time of surgery, grouped by age.**

\begin{tabular}{|c|c|c|c|c|c|}
\hline Column & A & B & C & D & E \\
\hline & $\begin{array}{l}\text { Type of } \\
\text { Nodule (n) }\end{array}$ & $\begin{array}{l}\text { Ratio } \\
\text { Benign } \\
\text { Cancer }\end{array}$ & $\begin{array}{l}\text { Percent } \\
\text { of (n) }\end{array}$ & $\begin{array}{l}\text { Total } \\
\text { Thyroid } \\
\text { Dose +/-SD }\end{array}$ & $\begin{array}{l}\text { Years to } \\
\text { Surgery } \\
+/ \text {-SD }\end{array}$ \\
\hline $\begin{array}{l}\text { Rong }<10 \mathrm{yr} \\
(\mathrm{n}=26)\end{array}$ & $\begin{array}{l}\text { Benign }(16)^{* * *} \\
\text { Cancer (1) } \\
\text { Adenomatous (16) } \\
\quad \text { nodules }\end{array}$ & $16: 1$ & $\begin{array}{r}62 \\
4 \\
62\end{array}$ & $\begin{array}{l}3289+/-1323 \\
2490 \\
3289+/-1323\end{array}$ & $\begin{array}{l}14+/-4 \\
15 \\
14+/-4\end{array}$ \\
\hline $\begin{array}{c}\text { Rong }>10 \mathrm{yr} \\
(\mathrm{n}=54)\end{array}$ & $\begin{array}{l}\text { Benign (5) } \\
\text { Cancer (4) } \\
\text { Adenomatous (4) } \\
\text { nodules }\end{array}$ & $1.25: 1$ & $\begin{array}{l}9 \\
7 \\
7\end{array}$ & $\begin{array}{r}856+/-649 \\
1415+/-150 \\
970+/-689\end{array}$ & $\begin{array}{l}19+/-5 \\
20+/-9 \\
19+/-5\end{array}$ \\
\hline $\begin{array}{l}\text { Utirik }<10 \text { yr } \\
(n=57)\end{array}$ & $\begin{array}{l}\text { Benign (7) } \\
\text { Cancer (2) } \\
\text { Adenomatous (3) } \\
\text { nodules }\end{array}$ & $3.5: 1$ & $\begin{array}{r}12 \\
4 \\
5\end{array}$ & $\begin{array}{c}509+/-137 \\
526 \\
478+/-178\end{array}$ & $\begin{array}{l}28+/-3 \\
26 \\
28+/-3\end{array}$ \\
\hline $\begin{array}{l}\text { Utirik }>10 \mathrm{yr} \\
(\mathrm{n}=102)\end{array}$ & $\begin{array}{l}\text { Benign (12) } \\
\text { Cancer (3) } \\
\text { Adenomatous (7) } \\
\text { nodules }\end{array}$ & $4.0: 1$ & $\begin{array}{r}11 \\
3 \\
7\end{array}$ & $\begin{array}{l}198+/-41 \\
168+/-6 \\
171+/-0\end{array}$ & $\begin{array}{l}24+/-4 \\
22+/-8 \\
23+/-8\end{array}$ \\
\hline
\end{tabular}

* If two thyroid nodules occurred in the same individual only the "higher grade" nodule was counted.

** Ten years of age is used as cut-off for the younger group because Rongelap children below this age received a mean thyroid-absorbed dose of $>2000 \mathrm{cGy}$ and thereby sustained extensive thyroid injury, a factor that influenced nodule type. All others received lower doses. Two in Utero Rongelap children who received $<2000 \mathrm{cGy}$ are not included in the table.

*** "Benign" nodules include adenomatous nodules, adenomas, and occult papillary carcinomas.

nodules over? Inspection of Fig. 4a shows that the answer to (1) is in the affirmative, at least for the Rongelap people. No adenomatous nodule has been found at surgery for 12 years. The detection of adenomatous nodules spanned 15 years beginning 9 years after exposure. For the Utirik group, detection spanned 12 years, beginning 19 years after exposure.

For question (2), the answer is less clear. Although only 1 neoplastic nodule (a carcinoma) has been diagnosed in the past 10 years in the
Rongelap population, several have been found in the Utirik group during the same period (Fig. 4b).

A striking observation is the virtually identical percent of neoplastic lesions that have occurred over thirty-six years of observation in the two exposed groups, being 8 individuals for the 86 Rongelap persons (9.3\%) and 15 individuals for the 167 Utirik persons $(9.0 \%)$. Given the great differences between the two groups in total-body and thyroidabsorbed radiation doses, it is clear that (1) other factors, such as the possibility of thyroid cell killing 

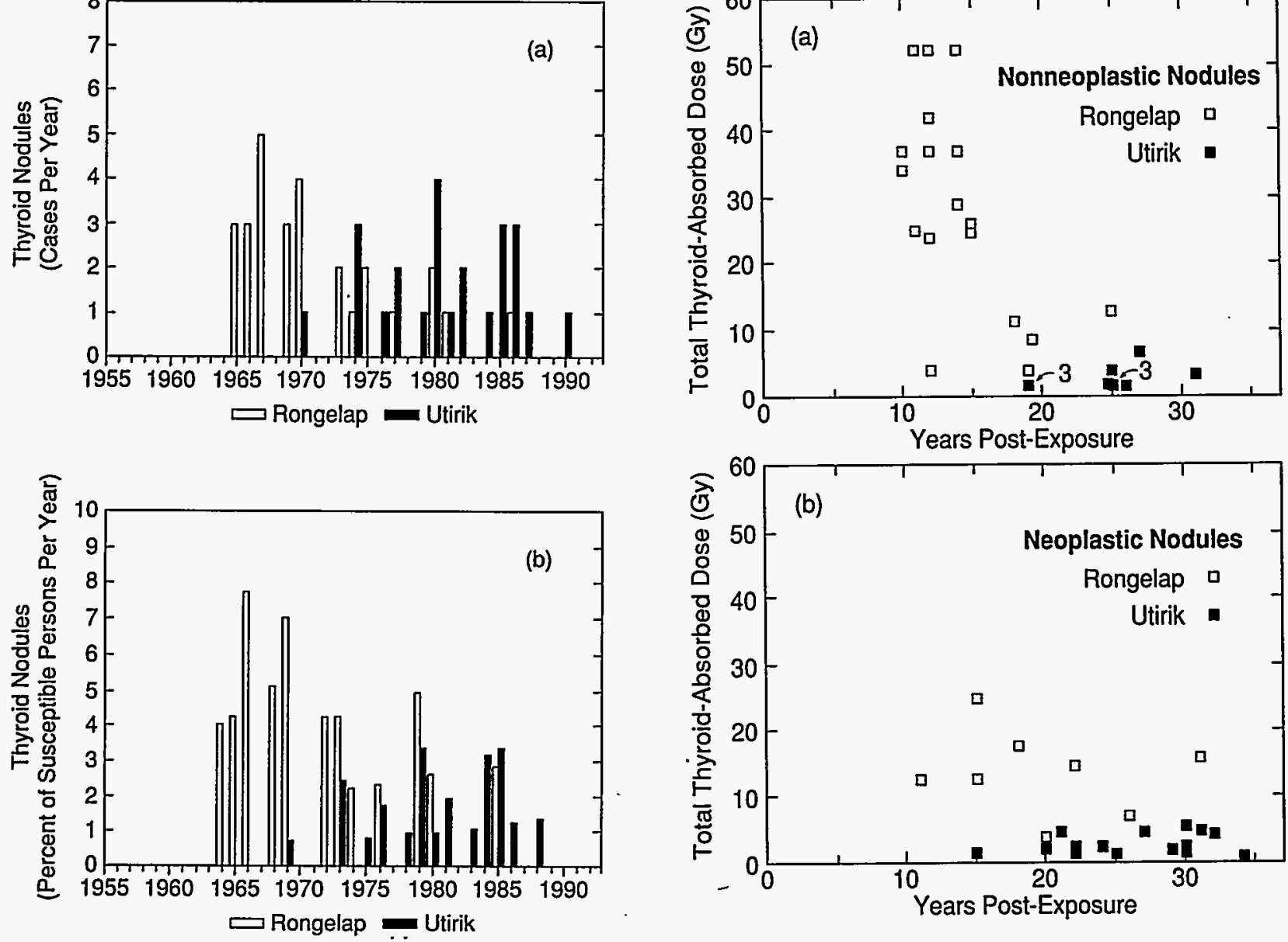

Fig. 3: Surgically confirmed thyroid nodules, Rongelap and Utirik exposed population. (a) Surgical cases per year; (b) surgical cases per year expressed as percent of the remaining susceptible population. (remaining individuals at risk to develop their first nodule).

at high doses, may have had a great effect of the ultimate type of nodule that develops, or (2) lumping of adenomas, occult papillary carcinomas, and overt carcinomas in one "neoplastic" category is not valid for this type of analysis. Probably both explanations are correct to some extent. It may be that high and low doses of radiation to the thyroid are equally neoplastigenic but not carcinogenic.

2) What was the role of gender in nodule development:

The distribution of various nodule types by gender (Table 4) shows a female preponderance for all categories of nodules. This is to be expected in all but the occult papillary carcinomas. Published data indicate that in the latter both genders are affected about equally, although sometimes there is a male preponderance (Woolner et al., 1960; Harach et al., 1985; Sampson et al., 1971).

Fig. 4: Relation of thyroid-absorbed dose to time of development of (a) non-neoplastic nodules (adenomatous nodules) and (b) neoplastic nodules (adenomas, occult papillary carcinomas, and overt thyroid carcinomas.)

The relation of radiation dose to time of development of all nodules is identical for males and females (Fig. 5).

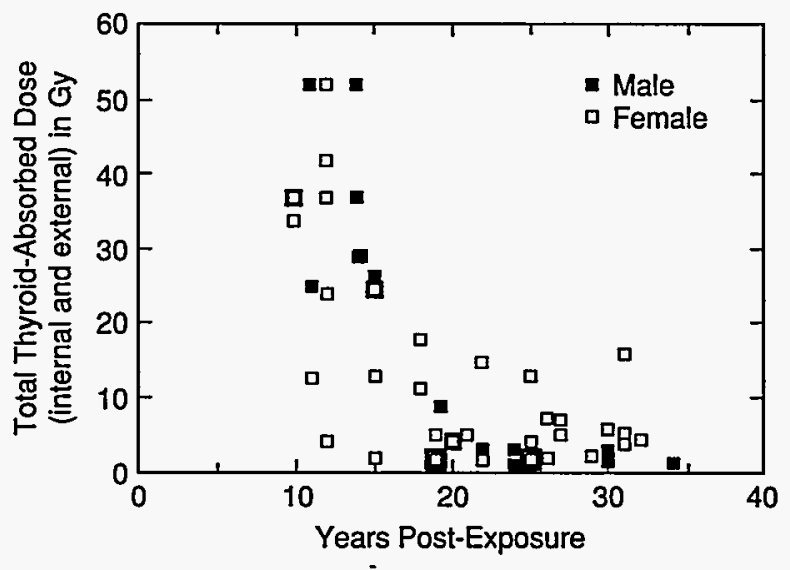

Fig. 5: Relation of thyroid-absorbed dose to time of development of surgically confirmed nodules, according to gender. 
TABLE 4: Distribution of thyroid nodule type by gender.

\begin{tabular}{llll}
\hline \hline & Male (\%) & Female $(\%)$ & Total \\
& $8(25)$ & $24(75)$ & 32 \\
Adenomatous nodules & $2(29)$ & $5(71)$ & 7 \\
Adenomas & $2(29)$ & $5(71)$ & 7 \\
$\begin{array}{l}\text { Occult papillary } \\
\text { carcinomas }\end{array}$ & $1(10)$, & $9(90)$ & 10 \\
Carcinomas & $13(23)$. & $43(77)$ & $56^{*}$ \\
\hline \multicolumn{1}{c}{ Total } & & \\
\hline \hline
\end{tabular}

* The total number of nodules exceeds the number of surgeries because four patients had two categories of nodules.

3) What was the relation of radiation dose to time of nodule detection?

The strong correlation between higher dose and earlier nodule development is shown in Fig. 5. While this graph gives an overview of the epidemic in relation to dose, it offers little understanding of the role of the variables that shaped it.

The predominant nodule type was the adenomatous nodule, the ratio of these to all other types being 4:3. Adenomatous nodules are not neoplastic. Therefore, Fig. 5 predominantly describes the relation of radiation dose to nonneoplastic nodular disease. Secondly, the prominent association of higher radiation dose with early nodule development is influenced by age-related variability in susceptibility to thyroid cancer (NRC BEIR V, 1990) and benign tumors (Ron et al., 1989; Shore et al., 1985). The mean age of the Rongelap people at the time of exposure was 27.6 years, but the range of ages was 0 (there were 4 persons in utero) to $>80$ years, and susceptibility would have varied accordingly.

Inferences concerning dose and time to development of adenomatous nodules can be extracted from data on persons exposed at equivalent ages, thereby controlling for susceptibility. In Figure 6 the time to development of nodules is graphed against dose in children one to six years of age. Three of these children were on Utirik (ages: 1, 5, and 6 years). The correlation between dose and time to development of adenomatous nodules was highly significant $(\mathrm{r}=-0.848 ; \mathrm{p}<0.001)$. Although the number of observations is small, these data suggest that the earlier development of adenomatous nodules was primarily a function of higher radiation dose to the thyroid, not age. One variable which is not controlled for is thyroxine prophylaxis for the Rongelap children. Prophylaxis was not initiated until ten years after exposure and after the first nodules had been detected. Therefore, the effect of thyroid suppression on development of thyroid nodules was not of consideration for the first 10 years after exposure. In addition almost all adenomatous nodules in this group had been identified within five years of initiation of thyroxine suppression.

A similar age-controlled analysis for the other three nodule types is not useful because there are too few observations per group.

4) What was the relation between nodule development and age at exposure?

The relation of nodule type to dose and age at exposure is shown in Fig. 7a-d. The graphs indicate a similarity in the age- and dose-related development of all four nodule types in the Utirik 
group. Only adenomas (Fig. 7b) did not develop in persons exposed beyond their teenage years.

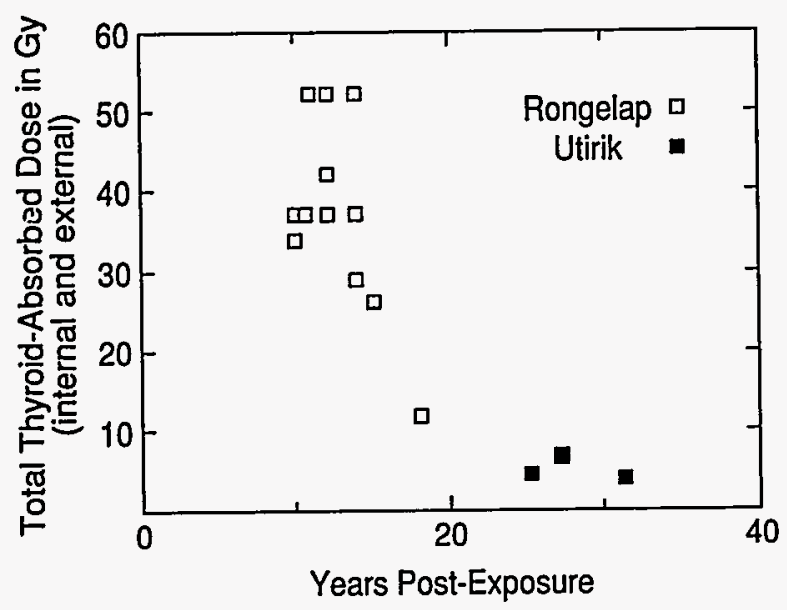

Fig 6: Relation of thyroid-absorbed dose to time of development of surgically conformed nodules in persons who were between 1 and 6 years of age at the time of exposure on Rongelap and Utirik.

However, there is a marked disparity among the four graphs for the Rongelap group. The occurrence of many adenomatous nodules in the younger Rongelap population (Fig. 7a) could have been a function of either age or high radiation dose, because the thyroid-absorbed dose was strongly age-dependent. However, none of the other three nodule types in the Rongelap exposed group (Fig. 7b-d) show the same preference for younger ages, although the number of observations is quite small. It is possible that the development of adenomas and occult papillary carcinomas, as well as overt carcinomas, was limited by thyroid cell injury resulting from the high radiation dose to the young Rongelap population. It is ironic that neoplastic nodules in the Rongelap group were numerically overshadowed by benign nonneoplastic lesions. While one might consider this to be, in a sense, a mitigation of radiation injury, the significant morbidity of benign thyroid nodules in the exposed Marshallese has been discussed (Adams et al., 1988).

5) Did benign nodules antedate carcinomas?

A highly significant correlation for time of development of benign nodules (either total benign nodules or adenomatous nodules) and thyroid cancers was found using mean time to surgery for the specified groups (Table 3, column E; $r=0.99$ and $p=<0.01$ ). This striking similarity, which is present regardless of age or the use of thyroxine suppression, supports the notion that a benign lesion does not evolve into a malignant one, nor do carcinomas, presumably possessing a greater degree of autonomous growth, manifest themselves clinically any earlier than benign nodules. Ron et al. (1989) also noted a similarity in time from radiation exposure to tumor diagnosis for carcinomas, adenomas, and "nodules."

6) Was the type of thyroid nodule induced by radiation a function of dose?

It is thought that at thyroid doses above 1500 $2000 \mathrm{cGy}$ the incidence of carcinoma is decreased due to extensive cell death which leaves few cells capable of becoming neoplastic (NCRP, 1985), although there are reports of undiminished risk of thyroid cancer from external irradiation with thyroid doses exceeding $3000 \mathrm{cGy}$ (Tucker et al., 1991). For palpable solitary nodules in the general population the usual ratio of benign to malignant lesions is about 6:1 and in some radiation-exposed groups it can be as high as 3:1 (DeGroot et al., 1983), although the ratio varies considerably depending on the definitions used. The ratios for the Marshallese are shown in Table 3, column B. In the Utirik group where the total thyroid dose was relative small the ratios for persons under 10 years of age is 3.5:1 and for those who were older it is 3.7:1. The high benign to malignant tumor ratio of $16: 1$ for Rongelap children who were exposed under the age of ten years and whose thyroid doses exceeded 2000 cGy is consistent with most other studies, and the likely explanation is a decrease in thyroid cancer due to extensive cell death or injury at the time of exposure.

What may also be important, however, is the low benign to malignant tumor ratio (1.25:1) found in those Rongelap individuals with mid-range thyroid radiation doses (i.e., Rongelap individuals over the age of 10 years at exposure, who received 400 to 2000 cGy). Thus, there was a high probability in this group of a detected nodule being malignant, whereas there was a relatively low probability of malignancy in persons whose dose exceeded 2000 cGy. This may be relevant in clinical decisionmaking for nodules detected in other exposed populations. 
These findings indicate that up to a point, perhaps in the range of $1500-2000 \mathrm{cGy}$, the greater the radiation dose the greater is the chance of a detected thyroid nodule being cancerous.

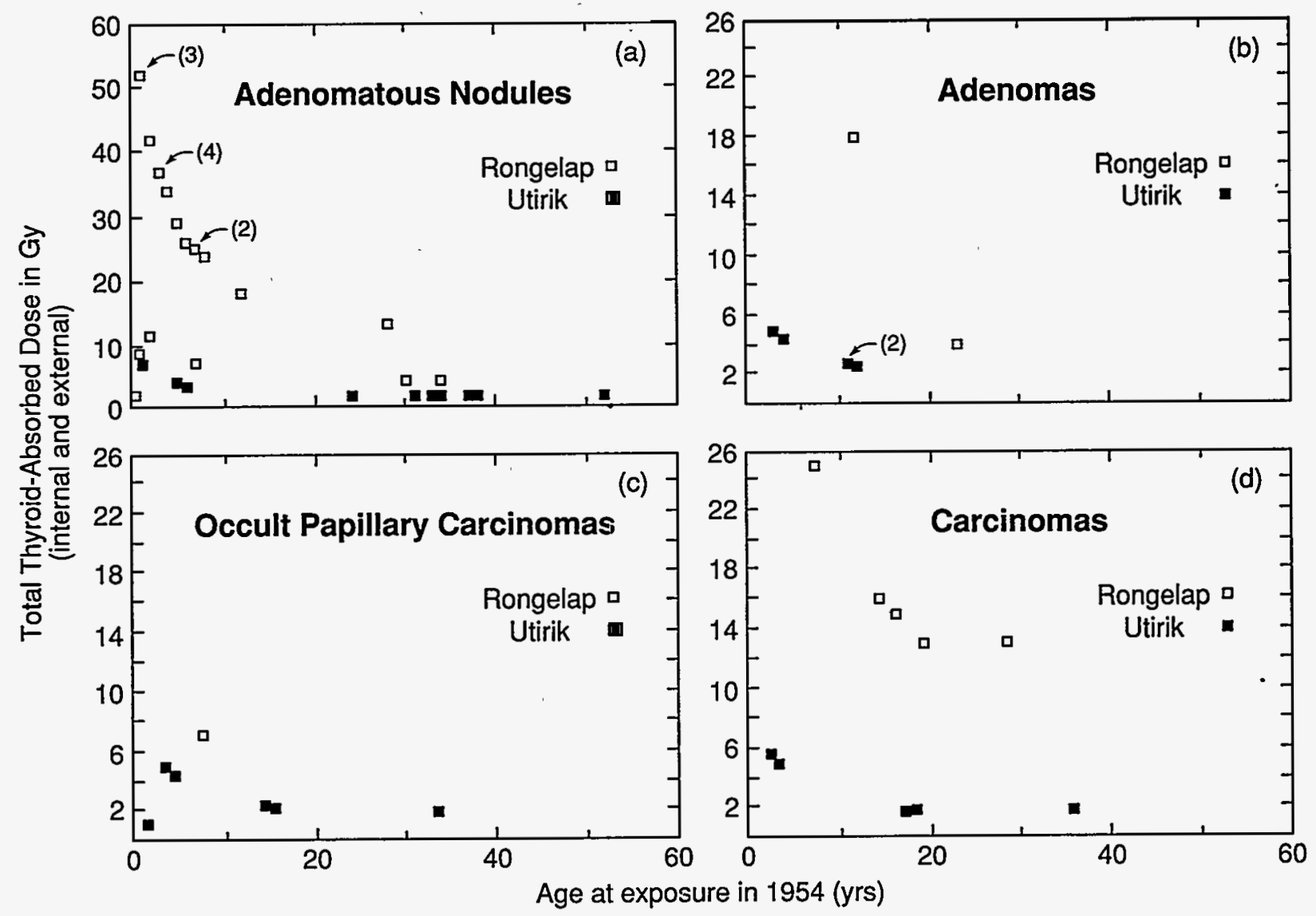

Fig. 7. Relation of thyroid-absorbed dose to age at exposure categorized by nodule histology.

7) Did radiation increase the incidence of "occult" carcinomas?

Occult thyroid carcinomas have been found in $6-36 \%$ of routine autopsies in many parts of the world (Fukunaga and Yatani, 1975; Harach et al., 1984), and the prevalence does not increase with age, in contrast to overt carcinomas and benign lesions. In 23 unexposed Marshallese undergoing thyroid surgery under the auspices of the Brookhaven medical program, $2(9 \%)$ had occult carcinomas. Reports from the Atomic Bomb
Casualty Commission in Japan indicated that occult thyroid carcinomas were increased by radiation exposure (Sampson et al., 1969), although there is at least one subsequent study from Nagasaki that found no such increase (Wakabayashi et al., 1983). In the exposed Marshallese a similar effect may also be present, for based on results of surgical exploration, 6 of 24 (25\%) of Utirik persons exposed to radiation (thyroid-absorbed doses ranging from 170 to $680 \mathrm{cGy}$ ) had occult carcinomas. However, in the Rongelap group, 
whose thyroid doses ranged from about 400 to $5200 \mathrm{cGy}$, only 1 of $28(4 \%)$ had the diagnosis of occult papillary carcinoma. If only those Rongelap individuals with doses less than 2000 cGy are analyzed, 1 of $13(8 \%)$ had an occult carcinoma, and for those receiving over $2000 \mathrm{cGy}$ the prevalence is $0 \%$. Therefore, the high radiation dose received on Rongelap may have decreased rather that increased the incidence of the occult tumors.

But a factor that renders any conclusion of questionable value is that in many of the surgical explorations the entire thyroid gland was not removed and subjected to the close histologic examination that has been used in most studies on occult papillary carcinoma prevalence. The Marshallese data may, therefore, underestimate the prevalence of these lesions, particularly in the multinodular adenomatous goiters of the exposed Rongelap children.

The combined number of occult papillary carcinomas and overt carcinomas in the Rongelap and Utirik groups is virtually identical, being $7.0 \%$ in the former and $6.6 \%$ in the latter:

$\begin{array}{lcc} & \text { Rongelap } & \text { Utirik } \\ \text { Exposed persons } & 86 & 167 \\ \text { Occult CA } & 1 & 6 \\ \text { Overt CA } & 5 & 5 \\ & & \\ \text { Total CA } & 6 & 11 \\ \text { Exposed/Total CA } & 7.0 \% & 6.6 \%\end{array}$

There are proportionally more carcinomas in the Rongelap group and more occult papillary carcinomas in the Utirik. One might wonder whether radiation exposure had the effect of inducing or hastening a change toward increasing virulence in the usually benign-acting "occult" lesions. However, such an interpretation does not take into account either the limitations on technique of histological examination of the thyroid mentioned in the preceding paragraph or the extensive thyroid injury in those in the Rongelap group who received more than $2000 \mathrm{cGy}$ to the thyroid.
8) Did thyroxine suppression decrease the incidence of benign and/or malignant nodules in radiationexposed persons?

Administration of thyroxin for the purpose of suppression of development of thyroid nodules in Marshallese who had been living on Rongelap at the time of exposure was initiated in 1965 shortly after the first thyroid nodules were detected (Conard et al., 1967). The distribution of thyroxine, subsequently extended to include those persons who were on nearby Ailingnae atoll, has been continued up to the present, with dose being determined by the results of yearly tests of thyroid function. Utirik patients are not routinely managed with thyroxine suppression. It is given to them only when clinically indicated as noted below. Every six months a supply of tablets is handed out to each exposed Rongelap person, whether or not that person appears for examination, and clinical decisions relating to thyroxine use are made each year by endocrinologic consultants who accompany the medical team during their work in the Marshall Islands. Thyroxine is also given to all persons who had thyroid surgery under the auspices of the Marshall Islands Medical Program, whether exposed or not, for replacement and suppression.

The value of suppressive therapy in prevention of thyroid cancer and benign nodule formation is not clearly determined. Various studies, for the most part carried out on persons who previously had treatment for thyroid nodules, have indicated (1) no nodule suppressive effect (DeGroot et al., 1983), (2) no cancer suppressive effect (Cady et al., 1983), (3) no suppression of benign nodules (Geerdsen and Frolund, 1984), and (4) a decrease in benign nodules but not malignant nodules (Fogelfeld et al., 1989). One study found that thyroxine reduced the number of recurrences in those who had previously undergone therapy for papillary thyroid carcinoma (Schneider et al., 1986), although the number of patients not given suppressive therapy was small. The timing of thyroxine prophylaxis may be an important factor in determining its effectiveness; if started some years after exposure its value may be lessened (DeGroot et al., 1983).

Any conclusions derived from the results of the Marshallese program have scientific limitations. The Rongelap group has been receiving thyroxine suppression since 1965 but it is known that compliance with this regimen is poor, estimated at no better than 50\% (Adams et al., 1983). The suppression was not initiated until 10 years after 
exposure. The number of persons in the Rongelap group is small and many were children at the time of exposure, thereby introducing sample size and age factor into the analysis. Finally, variations in the thyroid-absorbed radiation dose were primarily dependent on age at exposure, and therefore extensive destruction of thyroid tissue with a consequent decrease in risk of thyroid cancer may have occurred in the younger individuals (NCRP, 1985).

One inference is extractable from the Marshallese data by examining the ratios of benign to malignant nodules (Table 3 , column B). The Utirik population, which received no thyroxine suppression, had ratios of about 3.5:1 in children less than age ten and 3.7:1 in older children and adults, respectively. In the exposed Utirik group over the age of 10 the number of carcinomas which developed was 3 and the number of benign nodules was 11 . On the other hand, in the Rongelap group over the age of 10 , which was receiving thyroxine suppression, the number of carcinomas that developed was 4 and the number of benign nodules only 5 with a ratio of 1.25:1. Based on the number of thyroid cancers in the Utirik group, the number of benign Rongelap nodules in those exposed when they were over 10 years of age should have been about 15. That the relatively low number of benign nodules in this group was not the result of the higher radiation dose is seen in the plethora of benign nodules and the highest ratio of benign to malignant nodules in Rongelap children under ten years of age, all of whom received over $2000 \mathrm{cGy}$.

Thyroxine suppression may have resulted in the development of fewer benign nodules in the older population. (See above for the discussion concerning the limitations of the validity of this interpretation). It is not possible to determine if thyroxine prevented the development of benign nodules in Rongelap children under 10 years of age, in part because 15 of the total of 18 adenomatous nodules in this group had been detected within five years of starting suppression therapy and therefore were unlikely to have been much affected by prophylaxis. The incidence of thyroid cancer in Rongelap persons over 10 years of age was $7 \%$ and in the comparable Utirik population persons $4 \%$. The incidence in the former might have even been higher without thyroxine suppression but this will never be proven.
9) Did fetal radiation exposure produce thyroid nodules?

It is known that ${ }^{131} \mathrm{I}$ given in pregnancy can produce hypothyroidism in the fetus (Fisher et al., 1963). Since the fetal thyroid begins to concentrate iodine at about the twelfth week of pregnancy, risk of fetal thyroid injury from radioiodines begins at this time. Those fetuses at the time of exposure to BRAVO fallout received both a whole-body dose of gamma radiation equal to their mothers' and a radioiodine dose to the thyroid which was a function of age of gestation, maternal radioiodine dose, and the extent of placental transfer of the radioisotope. The placenta is not a barrier to iodine transfer (Fisher, 1975).

Twelve persons followed by the Marshall Islands Medical Program were in utero at the time of exposure, four from Rongelap and eight from Utirik. Three of these have now developed thyroid nodules: two of the four Rongelap children and one of the seven Utirik children (the eighth person in the latter group has never been available for examination). Table 5 summarizes the in utero exposure data. The finding that nodules (all benign) have occurred in at least 27 percent of those in utero at exposure is striking, particularly since the thyroid doses were not calculated to be very high in two of the three (Nos. 3 and 8, Table 5). None of those irradiated in utero have become spontaneously hypothyroid. Since the external whole-body dose estimates are probably fairly accurate, it may be that the internalized dose was higher in the three persons with nodules than was estimated. All the external and internal thyroid doses calculated by Lessard et al. (1985) were derived from a variety of data on radiation sources and conditions, and that report states that the maximum thyroid-absorbed dose could have been as much as four times the mean values used herein. Alternatively, the fetus may be more susceptible than the adult to radiogenic thyroid nodules and perhaps even more so than the juvenile thyroid. Among 2,802 Japanese atomic bomb survivors who were in utero at the time of exposure, 16 have developed cancers that appeared after the age of 14 years. One of these was a thyroid cancer which occurred in a person whose gestational age was 22 weeks at exposure (Yoshimoto et al., 1988). 
Table 5: Thyroid nodules occurring in those exposed in utero.

\begin{tabular}{lccl} 
ID No. & $\begin{array}{c}\text { Gestation age } \\
\text { at exposure } \\
\text { (in weeks) }\end{array}$ & $\begin{array}{c}\text { Estimated } \\
\text { thyroid dose* } \\
\text { (cGy) }\end{array}$ & Nodule type \\
\hline 1 & 23 & 870 & Adenomatous nodule \\
2 & 24 & 870 & \\
3 & 10 & 190 & Adenomatous nodule \\
4 & 4 & 190 & \\
5 & 17 & 270 & \\
6 & 24 & 110 & \\
7 & 16 & 270 & \\
8 & 33 & 110 & Occult papillary cancer** \\
9 & 24 & 110 & \\
10 & 32 & 110 & \\
11 & 35 & 110 & gestational age unknown \\
12 & Never examined: & & \\
\hline & & &
\end{tabular}

* Estimated total thyroid-absorbed dose, including internal and external exposures.

** Dividend opinion among the four consultants on the Pathology panel: occult papillary carcinoma (2) vs. adenomatous goiter (1) vs. nodule with fibrosis (1).

This reports shows that the mortality rate of the exposed Marshallese is no different from the unexposed population. The exposed population and the comparison group are too small in number to determine if there is a statistically significant difference in the incidence of neoplasia other than that of the thyroid. Ingestion of radioactive iodines by the exposed population, including the lesser exposed Utirik group, has resulted in an evident increased incidence of thyroid neoplasia even though this group is small, as is the comparison population. In the Rongelap group, one neoplastic nodule has been diagnosed in the prior ten years and several neoplastic nodules have been diagnosed in the Utirik group during the same time period. The increased risk of formation of thyroid neoplastic nodules appears to still be present, although probably at a decreasing rate. 


\section{REFERENCES}

Adams, W.H., Heotis, P.M., and Scott, W.A. 1988. Medical Status of Marshallese Accidentally Exposed to 1954 BRAVO Fallout Radiation: January 1985 through December 1987. BNL 52192.

Adams, W.H., Engle, J.R., Harper, J.A., Heotis, P.M., and Scott, W.A. 1985 Medical Status of Marshallese Accidentally Exposed to 1954 BRAVO Fallout Radiation: January 1983 through December 1984. BNL 51958.

Adams, W.H., Harper, J.A., Rittmaster, R.S., Heotis, P.M., and Scott, W.A. 1983 Medical Status of Marshallese Accidentally Exposed to 1954 BRAVO Fallout Radiation: January 1980 through December 1982. BNL 51761.

Adams, W.H., Fields, H.A., Engle, J.R., Hadler, S.C. 1986. Serologic markers for hepatitis B among Marshallese accidentally exposed to fallout radiation in 1954. Radiat. Res. 108:74-79.

Adams, W.H., Harper, J.A., Rittmaster, R.S., and Grimson, R.S. 1984. Pituitary tumors following fallout radiation exposure. J. Amer. Med. Assoc. 252:664-666.

Amonette, R.A. and Kaplan, R.J. 1976. Squamous-cell and basal-cell carcinomas in black patients. J. Derm. Surg. 2(2):158-161.

Annual Report 57-58, Atomic Bomb Casualty Commission, 1958.

Blaisdell, R.K. and Amamoto, K., Review of ABCC Hematologic Studies 1947-1959, Technical Report 25-55, Atomic Bomb Casualty Commission, Hiroshima and Nagasaki, Japan, 1966.

Brander, A., Viikinkoski, P., Nickels, J., and Kivisaari, L. 1989. Thyroid gland: US screening in middle-aged women with no previous thyroid disease. Radiology 173:507-510.

Burns, J.E., Eisenhauer, E.D., Jabaley, M.E., and Cruse, J.M. 1980. Cellular immune deficiency in black patients with basal cell carcinoma. J. Surg. Oncol. 13:129-134.
Cady, B., Cohn, K., Rossi, R.L., Sedgwick, C.E., Meissner, W.A., Werber, J., and Gelman, R.S. 1983. The effect of thyroid hormone administration upon survival in patients with differentiated thyroid carcinoma. Surgery 94:978-983.

Cohen, J., Gierlowski, T.C., and Schneider, A.B. 1990. A prospective study of hyperparathyroidism in individuals exposed to radiation in childhood. $J$. Amer. Med. Assoc. 264:581-584.

Conard, R.A., Meyer, L.M., Rall, J.E., Lowery, A., Bach, S.A., Cannon, B., Carter, E.L., Eicher, M., and Hechter, H. 1958. March 1957 Medical Survey of Rongelap and Utirik People Three Years after Exposure to Radioactive Fallout. BNL 501 (T-119).

Conard, R.A., Paglia, D.E., Larsen, P.R., Sutow, W.W., Dobyns, B.M., Robbins, J., Krotosky, W.A., Field, J.B., Rall, J.E., and Wolff, J. 1980. Review of Medical Findings in a Marshallese Population Twenty-Six Years after Accidental Exposure to Radioactive Fallout. BNL 51261.

Conard, R.A., Meyer, L.M., Sutow, W.W., Robertson, J.S., Rall, J.E., Robbins, J., Jesseph, J.E., Deisher, J.B., Hicking, A., Lanwi, I., Gusmano, E.A., and Eicher, M. 1967. Medical Survey of the People of Rongelap and Utirik Islands Eleven and Twelve Years after Exposure to Fallout Radiation (March 1965 and March 1966). BNL 50029.

Cronkite, E.P., Bond, V.P., Conard, R.A., Shulman, N.R., Farr, R.S., Cohn, S.H., Dunham, C.L., and Browning, L.E. 1955. Response of human beings accidentally exposed to significant fallout radiation. J. Amer. Med. Assoc. 159:430-434.

Cusick, J. 1981. Radiation-induced myelomatosis. N. Engl. J. Med. 304:204-210.

Datubo-Brown, D.D. 1991. Primary malignant skin tumors in Nigerians. J. Nat. Med. Assn. 83(4) 345348.

Davis, M.M., Hanke, C.W., Zollinger, T.W., Montebello, J.F., Hornback, N.B., and Norins, A.L. 1989. Skin cancer in patients with chronic radiation dermatitis. J. Am. Acad. Dermatol. 20(4):608-616. 
DeGroot, L.J., Reilly, M., Pinnameneni, K., and Refetoff, S. 1983. Retrospective and prospective study of radiation-induced thyroid disease. Amer. J. Med. 74:852-862.

Dobyns, B.M., and Hyrmer, B.A. 1992. The surgical Measurement of Benign and Malignant Thyroidal Neoplasma in Marshall Islanders Exposed to Hydrogen Bomb Fallout. World $J$. Surg. 16:126-140.

Finch, S.C. and Finch, C.A. 1988. Summary of the Studies at $A B C C-R E R F$ Concerning the Late Hematologic Effects of Atomic Bomb Exposure in Hiroshima and Nagasaki, Technical Report 23-88, Radiation Effects Research Foundation.

Fisher, W.D., Voorhess, M.L., and Gardner, L.I. 1963. Congenital hypothyroidism in infant following maternal $131 \mathrm{I}$ therapy. $J$. Pediatr. 62:132-146.

Fisher, D.A. 1975. Thyroid function in the fetus and newborn. Med. Clin. N. Amer. 59:1099-1107.

Fleming, I.D., Barnawell, J.R., Burlison, P.E., and Rankin, J.S. 1975. Skin cancer in black patients. Cancer 35:600-605.

Fogelfeld, L., Wiviott, M.B.T., Shore-Freedman, E., Blend, M., Bekerman, C., Pinsky, S., and Schneider, A.B. 1989. Recurrence of thyroid nodules after surgical removal in patients irradiated in childhood for benign conditions. $N$. Engl. J. Med. 320:835-840.

Fujiwara, S., Esaki, H., Spost, R., Akiba, S., Neriishi, K., Kodama, K., Yoshimitsu, K., Hosoda, Y., Shimaoka, K. 1990 . Hyperparathyroidism among Atomic Bomb Survivors in Hiroshima, 1986-88. Radiation Effects Research Foundation TR 8-90.

Fukunaga, F.H., and Yatani, R. 1975. Geographical pathology of occult thyroid carcinomas. Cancer 36:1095-1099.

Geerdsen, J.P. and Frolund, L. 1984. Recurrence of nontoxic goitre with and without postoperative thyroxine medication. Clin. Endocrinol. (Oxf) 21:529-533.
Harach, H.R., Franssila, K.O., and Wasenius, V-M. 1985. Occult papillary carcinoma of the thyroid: $A$ "normal" finding in Finland. A systematic autopsy study. Cancer 56:531-538.

Ichimaru, M., Ishimaru, T., Mikami, M., and Matsunaga, M. 1982. Multiple myeloma among atomic bomb survivors in Hiroshima and Nagasaki, 1950-1976: Relationship to radiation dose absorbed by marrow. J. Nat. Cancer Inst. 69:323-328.

Larsen, P.R., Conard, R.A., Knudsen, K.D., Robbins, J., Wolff, J., Rall, J.E., Nicoloff, J.T., and Dobyns, B.M. 1982. Thyroid hypofunction after exposure to fallout from a hydrogen bomb explosion. J. Amer. Med. Assoc. 247:1571-1575.

Lessard, E., Miltenberger, R., Conard, R., Musolino, S., Naidu, J., Moorthy, A., and Schopher, C. 1985. Thyroid-absorbed Dose for People at Rongelap, Utirik, and Sifo on March 1, 1954. BNL. 51882.

Maxon, H.R., Thomas, S.R., Saenger, E.L., Buncher, C.R., and Kereiakes, J.G. 1977. Ionizing irradiation and the induction of clinically significant disease in the human thyroid gland. Amer. J. Med. 63:967-978.

Mortensen, J.D., Bennett, W.A., and Woolner, J.B. 1954. Incidence of carcinoma in thyroid glands removed at 1000 consecutive routine necropsies. Surg. Fonum 5:659-663.

Myskowski, P.L., Gumpertz, E., and Safai, B. 1985. Basal cell carcinoma and breast carcinoma following repeated fluoroscopic examinations of the chest. Journal Article 24. 122-123.

National Council on Radiation Protection and Measurement, Induction of Thyroid Cancer by Ionizing Radiation. NCRP Report No. 80, 1985.

National Research Council, Health Effects of Exposure to Low Levels of Ionizing Radiation (BEIR V), 1990.

Oettle, A.G. 1963. Skin cancer in Africa. Natl. Cancer Inst. Monograph 10:197-214. 
Rallison, M.L., Dobyns, B.M., Meikle, A.W., Bishop, M., Lyon, J.L., and Stevens, W. 1991. Natural history of thyroid abnormalities: Prevalence, incidence, and regression of thyroid diseases in adolescents and young adults. Amer. J. Med. 91:363-370.

Robbins, J. and Adams, W.H. 1989. Radiation effects in the Marshall Islands, in: Radiation and the Thyroid, pp. 11-24, Nagataki, S. (Ed.), Excerpta Medical, Amsterdam.

Ron, E., Modan, B., Preston, D., Alfandary, E., Stovall, M., and Boice, J.D., Jr. 1989. Thyroid neoplasia following low-dose radiation in childhood. Radiat. Res. 120:516-531.

Ron, E., Modan, B., Preston, D., Alfandary, E., Stovall, M., and Boice, J.D. Jr. 1991. Radiationinduced Skin Carcinomas of the Head and Neck. Radiat. Res. 125:318-325.

Rosen, I.B., Palmer, J.A., Rowen, J., and Luk, S.C. 1984. Induction of hyperparathyroidism by radioactive iodine. Amer. J. Surg. 148:441-445.

Sampson, R.J., Key, C.R., Buncher, C.R., and Iijima, S. 1971. Smallest forms of papillary carcinoma of the thyroid. Arch. Path. 91:334-339.

Sampson, R.J., Key, C.R., Buncher, C.R., and Iijima, S. 1969. Thyroid carcinoma in Hiroshima and Nagasaki. J. Amer. Med. Assoc. 209:65-70.

Sasagawa, S., Yoshimoto, Y., Toyota, E., Neriishi, S., Yamakido, M., Matsuo, M., Hosoda, Y., and Finch, S.C. 1990. Phagocytic and bacterial activities of leukocytes in whole blood from atomic bomb survivors. Radiat. Res. 124:103-106.

Schneider, A.B., Recant, W., Pinsky, S.M., Yun Ryo, U., Bekerman, C., and Shore-Freedman, E. 1986. Radiation-induced thyroid carcinoma: Clinical course and results of therapy in 296 patients. Ann. Intern. Med. 105:405-412.

Shore, R.E., Woodward, E., Hildreth, N., Dvoretsky, P., Hempelmann, L., and Pasternack, B. 1985. Thyroid tumors following thymus irradiation. J. Natl. Cancer Inst. 74:1177-1184.
Shore, R.E., Albert, R.E., Reed, M., Harley, N., and Pasternack, B.S. 1984. Skin cancer incidence among children irradiated for ringworm of the scalp. Radiat. Res. 100:192-204.

Takasu, N., Yamada, T., Takasu, M., Komiya, I., Nagasawa, Y., Asawa, T., Shinoda, T., Aizawa, T., and Koizumi, Y. 1992. Disappearance of thyrotropin-blocking antibodies and spontaneous recovery from hypothyroidism in autoimmune thyroiditis. N. Engl. J. Med. 326:513-518.

Tucker, M.A., Morris Jones, P.H., Boice, J.D., Robison, L.L., Stone, B.J., Stovall, M., Jenkin, R.D.T., Lubin, J.H., Baum, E.S., Siegel, S.E., Meadows, A.T., Hoover, R.N., and Fraumeni, J.F., Jr. 1991. Therapeutic radiation at a young age is linked to secondary thyroid cancer. Cancer Res. 51:2885-2888.

Wakabayashi, T., Kato, H., Ikeda, T., and Schull, W.J. 1983. Studies of the mortality of A-bomb survivors, Report 7. Radiat. Res. 93:112-146.

Walther, R.R., Grossman, M.E., and Troy, J.L. 1981. Basal-cell carcinomas on the scalp of a black patient many years after epilation by X-rays. $J$. Dermatol. Surg. Oncol. 7(7):570-571.

Woolner, L.B., Lemmon, M.L., Beahrs, O.H., Black B.M., and Keating, F.R., Jr. 1960. Occult papillary carcinoma of the thyroid gland: A study of 140 cases observed in a 30-year period. J. Clin. Endocrinol. Metab. 20:89-105.

Yoshimoto, Y., Kato, H., and Schull, W.J. 1988. Risk of Cancer among In Utero Children Exposed to A-Bomb Radiation, 1950-1984. Radiation Effects Research Foundation, RERF TR 4-88. 


\section{APPENDIX A \\ PROFESSIONAL STAFF PARTICIPATING IN THE 1988-91 MARSHALL ISLANDS SURVEYS}

\begin{tabular}{|c|c|c|c|}
\hline NAME & $\begin{array}{l}\text { PARTICIPATING } \\
\text { SURVEY }\end{array}$ & SPECLALTY & AFFILIATION \\
\hline Adams, W., M.D. & $\begin{array}{l}3 / 88,9 / 88,3 / 89 \\
3 / 90,9 / 90,3 / 91 \\
9 / 91\end{array}$ & $\begin{array}{l}\text { Head, CRC, 1986-1990, } \\
\text { Director, MIMP, Internal } \\
\text { Medicine, Hematology }\end{array}$ & $\begin{array}{l}\text { Medical Dept., Brookhaven } \\
\text { Natl. Lab, Upton, NY } 11973\end{array}$ \\
\hline Aron, D., M.D. & $3 / 89,3 / 90$ & $\begin{array}{l}\text { Chief, Endocrine Section } \\
\text { Assoc., Prof. of Medicine }\end{array}$ & $\begin{array}{l}\text { Case Western Reserve Univ., } \\
\text { Cleveland, OH }\end{array}$ \\
\hline Bauman, A., M.D. & $3 / 88$ & $\begin{array}{l}\text { Assist. Prof. of Medicine, } \\
\text { Internal Medicine, } \\
\text { Endocrinology }\end{array}$ & $\begin{array}{l}\text { Dartmouth Medical School, } \\
\text { Hanover, NH }\end{array}$ \\
\hline Berdouses, E., D.D.S. & $9 / 91$ & Ped. Dentistry & $\begin{array}{l}\text { Rutgers University, Newark, } \\
\text { NJ }\end{array}$ \\
\hline Bliss, M., M.D. & $9 / 87,9 / 89,3 / 91$ & $\begin{array}{l}\text { Prof. of Medicine, } \\
\text { Gastroenterology, Internal } \\
\text { Medicine }\end{array}$ & $\begin{array}{l}\text { Boston City Hospital, } \\
\text { Boston, MA } 02118\end{array}$ \\
\hline Buchanan, B., R.N. & $3 / 91$ & Nurse & Kwajalein Hosp., M.I. \\
\hline Calmon, J., M.D. & $3 / 89$ & $\begin{array}{l}\text { Instructor of Medicine, } \\
\text { Internal Medicine }\end{array}$ & $\begin{array}{l}\text { Med. College of Penn., } \\
\text { Phila., PA }\end{array}$ \\
\hline Cervoni, M., M.D. & $3 / 90$ & $\begin{array}{l}\text { Internal Medicine } \\
\text { Pulmonary }\end{array}$ & $\begin{array}{l}\text { Walter Reed Med. Ctr., } \\
\text { Washington, D.C. }\end{array}$ \\
\hline Cizinsky, J., Pharm.D. & $3 / 88,3 / 91$ & Pharmacy & $\begin{array}{l}\text { Med. Dept., Brookhaven } \\
\text { Natl. Lab, Upton, NY }\end{array}$ \\
\hline Connolly, H., M.D. & $3 / 91$ & Cardiology & Mayo Clinic, Rochester, MN \\
\hline Cook, K., M.D. & $9 / 88$ & Family Practice & $\begin{array}{l}\text { Private Practice, Houston, } \\
\text { TX; Kwaj Hosp., Kwajalein, } \\
\text { MI }\end{array}$ \\
\hline Dobyns, B., M.D. & $3 / 89$ & Prof. of Surgery & $\begin{array}{l}\text { Case Western Reserve Univ., } \\
\text { Cleveland Gen. Hosp., } \\
\text { Cleveland, } \mathrm{OH}\end{array}$ \\
\hline
\end{tabular}




\begin{tabular}{|c|c|c|c|}
\hline Donato, D., M.D. & $3 / 90$ & $\begin{array}{l}\text { Assist. Prof., Division of } \\
\text { Gynecology }\end{array}$ & $\begin{array}{l}\text { Univ. of Miami Med. School, } \\
\text { Miami, FL }\end{array}$ \\
\hline Dunlop, W., M.D. & $3 / 91$ & Ophthalmology & $\begin{array}{l}\text { Trippler Army Medical } \\
\text { Center, Honolulu, HI }\end{array}$ \\
\hline Dwyer, M., M.D. & $3 / 89$ & $\begin{array}{l}\text { Chief Resident } \\
\text { Opthalmology }\end{array}$ & $\begin{array}{l}\text { Walter Reed Army Medical } \\
\text { Center, Washington, DC }\end{array}$ \\
\hline Fikrig, S., M.D. & $3 / 90$ & $\begin{array}{l}\text { Prof. and Chairman, Dept. } \\
\text { of Pediatrics }\end{array}$ & $\begin{array}{l}\text { SUNY Health Center, } \\
\text { Brooklyn, NY }\end{array}$ \\
\hline Gardiner, M., M.D. & $3 / 89,9 / 89,3 / 91$ & $\begin{array}{l}\text { Rheumatology } \\
\text { Fellow/Internal Medicine }\end{array}$ & $\begin{array}{l}\text { Div. of Rheumatology } \\
\text { Medical College of Penn., } \\
\text { Philadelphia, PA }\end{array}$ \\
\hline George, D., M.D. & $3 / 91$ & Opthalmology & $\begin{array}{l}\text { Trippler Army Medical } \\
\text { Center, Honolulu, HI }\end{array}$ \\
\hline Green, A., M.D. & $3 / 89$ & $\begin{array}{l}\text { Assist. Prof. Clinical } \\
\text { Medicine, Endocrinology }\end{array}$ & $\begin{array}{l}\text { SUNY Stony Brook, Stony } \\
\text { Brook, NY }\end{array}$ \\
\hline Harper, J., M.D. & $3 / 88,3 / 91$ & $\begin{array}{l}\text { Family Practice (former } \\
\text { Resident Physician) }\end{array}$ & $\begin{array}{l}\text { Maine Med. Ctr., Portland, } \\
\text { ME } 04103\end{array}$ \\
\hline Heine, E. & $3 / 89$ & Nurse (Retired) & $\begin{array}{l}\text { Armer Ishoda Mem. Hosp., } \\
\text { Majuro, MI }\end{array}$ \\
\hline Heine, $R$. & $3 / 91$ & Nurse & $\begin{array}{l}\text { Armer Ishoda Mem. Hosp., } \\
\text { Majuro, MI }\end{array}$ \\
\hline Howard, J., M.D. & $9 / 91$ & $\begin{array}{l}\text { Asst. Director, MIMP, } \\
\text { Internal Medicine } \\
\text { Hematology/Oncology }\end{array}$ & $\begin{array}{l}\text { Med. Dept., Brookhaven } \\
\text { Natl. Lab, Upton, NY }\end{array}$ \\
\hline Howieson, J., M.D. & $3 / 90$ & Prof. of Radiology & $\begin{array}{l}\text { Oregon Health Sciences } \\
\text { Univ., Portland, Oregon }\end{array}$ \\
\hline Hurowitz, J., M.D. & $3 / 88$ & $\begin{array}{l}\text { Chief of Medicine, } \\
\text { Internal Medicine }\end{array}$ & $\begin{array}{l}\text { Worster State Hosp. Univ. of } \\
\text { Mass. Med. School, Worster, } \\
\text { MA }\end{array}$ \\
\hline Jacob, D. & $3 / 88$ & Nurse & $\begin{array}{l}\text { Armer Ishoda Mem. Hosp., } \\
\text { Majuro, MI }\end{array}$ \\
\hline Jagannath, A., M.D. & $3 / 88$ & Radiology Resident & $\begin{array}{l}\text { The NY Hosp/Cornell NY, } \\
\text { NY }\end{array}$ \\
\hline Kabua, J., R.N. & $\begin{array}{l}3 / 88,9 / 88,3 / 89 \\
9 / 89,3 / 90,3 / 91 \\
9 / 91\end{array}$ & Nurse (Retired) & $\begin{array}{l}\text { BNL-MIMP } \\
\text { Ebeye, MI }\end{array}$ \\
\hline
\end{tabular}


Kaiko, R.

Kern, J., M.D.

Kilwe, $\mathrm{H}$.

Kramer, K., M.D.

Krippaehne, M., M.D.

Lai, A., M.D.

Lakshmanan, M., M.D.

$3 / 90,3 / 91$

$3 / 90$

$9 / 88$

$3 / 88$

$9 / 89$

Lindborg, E., M.D.

Loes, Louis, M.D.

Magner, J., M.D.

$3 / 90$

McClintock, C.,

McCullough, A., M.D.

Melkonia, $\mathbf{R}$.

Mellan, M.

$3 / 90$

$3 / 89$

$3 / 90$

$3 / 91$

$5 / 87$

$9 / 88$
Prof. of Medicine

Obsterics/Gynecology

Fellow, Endocrinology Instructor, Endocrinology

Nurse

Nurse

Prof., Dept. of Obsterics/Gynecology

Emergency Medicine

Obsterics/Gynecology

Assoc. Prof. of Medicine, Endocrinology

$3 / 88,3 / 89,3 / 90$ Gastroenterology

Internal Medicine

Obstetrics/Gynecology

Nurse
Chief of GI Section,
Armer Ishoda Mem. Hosp., Majuro, MI

Walter Reed Army Medical Center, Washington, D.C.

Armer Ishoda Mem. Hosp., Majuro, MI

Walter Reed Army Medical Center, Washington, DC

Oregon Health Sciences Univ., Portland, Oregon

Univ. of Miami School of Med., Miami, FLA

NIH; Dept. of Rad., Metro Health Medical Ctr., Clevland, $\mathrm{OH}$

Armer Ishoda Mem. Hosp., Majuro, MI

Armer Ishoda Mem. Hosp., Majuro, MI

Univ. of Miami School of Med., Miami, FLA

USAKA Hosp., Kwajalein, MI

Retired, Womens \& Childrens Med. Ctr., Minneapolis, $\mathrm{MN}$

Michael Reese Hosp., Univ. of IIl., Chicago, IL

Woodhull Med. Ctr, Brooklyn, NY

N.E. Deaconess Hosp., Boston, MA

Stony Brook Univ. Hosp., Stony Brook, NY

Armer Ishoda Mem. Hosp., Majuro, MI 
Naylor, R.

$3 / 89$

Netusil, N., R.N.

O'Connel, B., M.D.

Prem, K, M.D.

Rantak, N.

Riklon, A.

Samuel, A.

Schaenen, W., M.D.

Takemura, B.

Terzuoli, R., M.D.

Vaswani, A., M.D.

Weiss, M., M.D.

White, J. M.D.

Wilson, R., M.D.

Young, D., M.D.

Ysawa, W.
$3 / 90,3 / 91$

$9 / 89$

$5 / 89,3 / 89$

$3 / 89,3 / 93$

$3 / 89 ; 3 / 90,3 / 91$

$3 / 91$

$3 / 88$

$3 / 90$

$9 / 90$

$3 / 91$

$9 / 91$

$3 / 91$

$3 / 89$

$3 / 91$

$3 / 90$
Chief, Radiology, Nuclear Medicine

Nursing

Assist. Prof. Dept. of Obstetrics/Gynecology

Prof. of

Obstetrics/Gynecology

Nurse

Nurse

Nurse

Internal Medicine, Attending Physician

Nurse

Opthalmology

Endocrinology

Pediatrics

Internal Medicine

Family Practice, Director of Diabetes Program, Zuni Wellness Ctr.

Prof. of Radiology

Nurse
VA Hosp., White River Jct., VT

CRC, Med. Dept., Brookhaven Natl. Lab, Upton, NY

Univ. of Wisconsin, Madison, WI

Dept. of OB/GYN, Univ of Med. School, Minn, MN

Armer Ishoda Mem. Hosp., Majuro, MI

Armer Ishoda Mem. Hosp., Majuro, MI

Armer Ishoda Mem. Hosp., Majuro, MI

NY Univ./Bellevue NYC, NY

Armer Ishoda Mem. Hosp., Majuro, MI

Private Practice, NYC, NY

Winthrop Univ. Hosp., Mineola, NY

Boston Childrens Hosp., Boston, NY

Natl. Instit. of Health, Bethesda, MD

Zuni PHS Indian Hosp., Zuni, AZ

Univ. of Iowa, IA

College of Micronesia, Majuro, MI 
Baso, S.

Benton, Mary Ann

DeBrum, $\mathbf{R}$.

Emos, Helmer

Ferguson, Robert

Garcia, M.

Gatz, III, Joseph

Harris, L.

Heinrichs, John

Heotis, Peter

Jacob, Stanley

Lehman, William

Mitzutani, Kosang

Riklon, K.

Saul, Joe
$3 / 91$

$9 / 89$

$3 / 88,9 / 88,3 / 89$, $9 / 89,3 / 90,3 / 91$, $9 / 91$

$9 / 88,3 / 88,3 / 89$, $9 / 89,3 / 90,9 / 90$, $3 / 91,9 / 91$,

$9 / 88$

$3 / 91$

$3 / 89$

$3 / 91,9 / 91$

$3 / 90$

$3 / 88,9 / 88,3 / 89$, $9 / 89,3 / 90,9 / 90$, $3 / 91,9 / 91$

9/88, 3/89, 3/90, $9 / 91$

$3 / 88,3 / 89,3 / 90$

$3 / 89,9 / 89,3 / 90$, 9/90, 3/91, 9/91,

$3 / 91$.

$3 / 89$
Armer Ishoda Mem. Hosp., Majuro, MI

Santa Fe, NM

U.S. Dept. of Energy,

Majuro, MI 96960

Med. Dept., Brookhaven Natl. Lab, Stationed at Ebeye, MI

Pensacola, FL

Garden City, NY

Med. Dept., Brookhaven Natl. Lab, Upton, NY 11973

Honolulu, HI

Med. Dept., Brookhaven Natl. Lab, Upton, NY 11973

Med. Dept., Brookhaven Natl. Lab, Upton, NY 11973

Ebeye Hosp, Ebeye, MI 96960

Med. Dept., Brookhaven Natl. Lab, Upton, NY 11973

Majuro, MI

Armer Ishoda Mem. Hosp., Majuro, MI

Armer Ishoda Mem. Hosp., Majuro, MI 
Scott, Wm.

Shoniber, Sebio

Slivka, Wm.

Takamura, B.

Tarbilin, $\mathbf{R}$.

Tommy, Morris

Ulyat, Harry
$3 / 88,9 / 88,3 / 89$,

9/89, 3/90, 9/90, $3 / 91,9 / 91$,

$3 / 88,9 / 89,3 / 90$

$3 / 90$

$9 / 90$

$3 / 91$

$5 / 87,9 / 87,3 / 88$

$3 / 88,3 / 89$,
Med. Dept., Brookhaven

Natl. Lab, Upton, NY 11973

Armer Ishoda Mem. Hosp., Majuro, MI 96960

Walter Reed Army Medical Center, Washington, D.C.

Armer Ishoda Mem. Hosp., Majuro, MI 96960

Armer Ishoda Mem. Hosp., Majuro, MI 96960.

Armer Ishoda Mem. Hosp., Majuro, MI

Med. Dept., Brookhaven

Natl. Lab, Upton, NY 11973 


\section{APPENDIX B}

Individual Marshallese laboratory data collected during 1988 through 1991 medical surveys. (* = exposed persons of Rongelap and Ailingnae; ${ }^{* *}=$ Utirik exposed; $^{* * *}=$ Comparison group).

Abbreviations:

\begin{tabular}{|c|c|c|}
\hline PID & $=$ & Brookhaven National Laboratory identification number \\
\hline SEX & $=$ & 1 - Male; 2 - Female \\
\hline AGE & $=$ & years \\
\hline WBC & $=$ & leukocyte count $/ \mu 1$ \\
\hline PMN & $=$ & neutrophil count $/ \mu \mathrm{l}$ \\
\hline BAND & $=$ & band forms $/ \mu 1$ \\
\hline LYMPH & $=$ & lymphocytes $/ \mu \mathrm{l}$ \\
\hline MONO & $=$ & monocytes $/ \mu 1$ \\
\hline EOS & $=$ & eosinophils/ $\mu 1$ \\
\hline BASO & $=$ & basophils $/ \mu \mathrm{l}$ \\
\hline PLT & $=$ & platelet count $\times 10^{3} / \mu 1$ \\
\hline HCT & $=$ & percent \\
\hline $\mathbf{R B C}$ & $=$ & erythrocytes $\mathrm{X} 10^{6} / \mu \mathrm{l}$ \\
\hline $\mathrm{MCV}$ & $=$ & mean corpuscular volume in $\mathrm{fl}$ (cu. microns) \\
\hline HGB & $=$ & hemoglobin level in $\mathrm{g} / \mathrm{dl}$ \\
\hline TSH & $=$ & thyroid stimulating hormone level in $\mu \mathrm{IU} / \mathrm{ml}$ \\
\hline PRL & $=$ & serum prolactin in $\mathrm{ng} / \mathrm{ml}$ \\
\hline FBS & $=$ & fasting blood sugar in $\mathrm{mg} / \mathrm{dl}$ \\
\hline HBA1C & $=$ & glycosylated hemoglobin $\mathrm{A} 1 \mathrm{C}$ in percent \\
\hline RBS & $=$ & random blood sugar in $\mathrm{mg} / \mathrm{dl}$ \\
\hline CAL & $=$ & calcium in $\mathrm{mg} / \mathrm{dl}$ \\
\hline TPR & $=$ & total protein in $\mathrm{g} / \mathrm{dl}$ \\
\hline
\end{tabular}




\section{APPENDIX B (CONT'D)}

NOTES: $\quad$ Series of 9's indicate test not performed.

Series of 0's indicate test performed but results below lower limit of detection.

Normal values for the laboratory are those of the U.S. population. Detailed ranges are on file at Brookhaven National Laboratory. 
COMPUTER IISTING OF 1988 RAW DATA

PMN BAND LYMPH MONO

EOS BASO PLT HCT RBC

$\mathrm{MCV}$ HGB

TSH

PRL FBS HBAIC

$\begin{array}{rll}2 & 1 & 35 \\ 3 & 1 & 35 \\ 4 & 1 & 72 \\ 5 & 1 & 35 \\ 6 & 1 & 35 \\ 7 & 1 & 68 \\ 8 & 2 & 35 \\ 9 & 1 & 54 \\ 10 & 1 & 58 \\ 12 & 2 & 50 \\ 14 & 2 & 58 \\ 15 & 2 & 41 \\ 16 & 1 & 73 \\ 17 & 2 & 37 \\ 18 & 2 & 55 \\ 19 & 1 & 39 \\ 20 & 1 & 40 \\ 21 & 2 & 36 \\ 22 & 2 & 50 \\ 24 & 2 & 47 \\ 33 & 2 & 35 \\ 34 & 2 & 78 \\ 36 & 1 & 41 \\ 39 & 2 & 48 \\ 40 & 1 & 63 \\ 41 & 1 & 75 \\ 42 & 2 & 36 \\ 44 & 1 & 38 \\ 45 & 2 & 65 \\ 47 & 1 & 42 \\ 48 & 2 & 39 \\ 49 & 2 & 50 \\ 53 & 2 & 41 \\ 61 & 2 & 42 \\ 63 & 2 & 69 \\ 64 & 2 & 64 \\ 66 & 2 & 63 \\ 67 & 2 & 47 \\ 70 & 2 & 50 \\ 71 & 2 & 60 \\ 72 & 2 & 41 \\ 73 & 1 & 52 \\ 74 & 2 & 49 \\ 75 & 2 & 45 \\ 76 & 1 & 44 \\ 78 & 2 & 69 \\ 81 & 2 & 42 \\ 83 & 1 & 33 \\ 85 & 1 & 33 \\ 86 & 2 & 33 \\ 05 & 2 & 34 \\ 11 & 2 & 34 \\ 15 & 1 & 37 \\ 16 & 2 & 38 \\ & & \end{array}$

$\begin{array}{rrrrrr}9900 & 99999 & 99999 & 99999 & 99999 & 99999 \\ 11200 & 5824 & 112 & 3920 & 784 & 560 \\ 7400 & 3108 & 0 & 3626 & 148 & 518 \\ 5200 & 2496 & 52 & 2236 & 104 & 312 \\ 9600 & 6336 & 0 & 2784 & 96 & 288 \\ 7500 & 3375 & 75 & 3675 & 225 & 75 \\ 11300 & 5537 & 113 & 3503 & 565 & 1130 \\ 9400 & 5545 & 0 & 3008 & 470 & 376 \\ 6900 & 4070 & 0 & 2070 & 207 & 483 \\ 9100 & 4459 & 0 & 4004 & 273 & 364 \\ 7300 & 2993 & 0 & 3577 & 438 & 292 \\ 10400 & 4784 & 104 & 3328 & 520 & 1560 \\ 6100 & 3233 & 122 & 2013 & 305 & 427 \\ 6500 & 3575 & 0 & 2470 & 325 & 130 \\ 7800 & 4368 & 0 & 2808 & 78 & 546 \\ 7100 & 5183 & 0 & 1633 & 0 & 284 \\ 6500 & 4030 & 130 & 1755 & 260 & 325 \\ 6200 & 3658 & 0 & 2046 & 310 & 124 \\ 5500 & 2695 & 0 & 2255 & 110 & 440 \\ 6400 & 2304 & 64 & 3392 & 64 & 576 \\ 10700 & 7918 & 0 & 1819 & 749 & 214 \\ 8400 & 3444 & 84 & 4368 & 168 & 336 \\ 8100 & 4860 & 0 & 2592 & 405 & 162 \\ 8500 & 3995 & 0 & 3995 & 255 & 85 \\ 8300 & 3403 & 83 & 4648 & 0 & 166 \\ 6900 & 3795 & 207 & 2484 & 345 & 69 \\ 9500 & 6650 & 0 & 2090 & 665 & 95 \\ 6400 & 2560 & 0 & 2880 & 448 & 512 \\ 9300 & 5208 & 0 & 2976 & 465 & 465 \\ 8600 & 5332 & 172 & 2150 & 344 & 602 \\ 8100 & 5103 & 0 & 2511 & 324 & 162 \\ 9700 & 4462 & 0 & 4074 & 485 & 582 \\ 6900 & 3312 & 0 & 3174 & 345 & 69 \\ 9700 & 3686 & 0 & 4850 & 291 & 873 \\ 6600 & 2772 & 66 & 3432 & 66 & 198 \\ 6300 & 3465 & 0 & 1953 & 252 & 567 \\ 7800 & 3666 & 156 & 3588 & 234 & 156 \\ 7700 & 3542 & 0 & 3311 & 231 & 616 \\ 7300 & 3723 & 0 & 1752 & 438 & 1095 \\ 8100 & 4860 & 81 & 2349 & 162 & 567 \\ 11200 & 6944 & 224 & 3584 & 336 & 112 \\ 6800 & 99999 & 99999 & 99999 & 99999 & 99999 \\ 12800 & 6784 & 384 & 4608 & 512 & 384 \\ 10800 & 5832 & 0 & 2808 & 432 & 1512 \\ 7300 & 3723 & 0 & 2993 & 219 & 365 \\ 7700 & 3465 & 77 & 3542 & 462 & 154 \\ 7100 & 4473 & 0 & 2272 & 284 & 71 \\ 7300 & 2482 & 73 & 3285 & 803 & 657 \\ 10300 & 5253 & 103 & 4223 & 618 & 103 \\ 6300 & 4599 & 0 & 1260 & 63 & 378 \\ 5600 & 1400 & 0 & 2632 & 672 & 896 \\ 10900 & 4360 & 109 & 5559 & 436 & 218 \\ 5400 & 3348 & 0 & 1728 & 108 & 162 \\ 7200 & 4104 & 144 & 2592 & 216 & 432\end{array}$

$275 \quad 43.3 \quad 4.41$

98.015 .4

6.60

8.4999 .999 .9

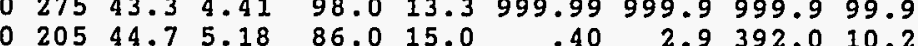

$\begin{array}{llllllllll}0 & 255 & 43.3 & 4.57 & 96.0 & 14.3 & .40 & 2.9 & 392.0 & 10.2\end{array}$

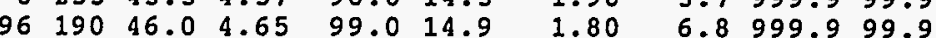

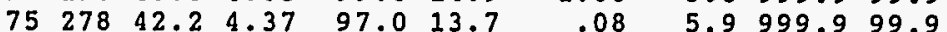
$\begin{array}{llllllll}52 & 295 & 45.1 & 4.84 & 93.0 & 14.6 & 04 & 2.5 \\ 0 & 999.9 & 99.9\end{array}$

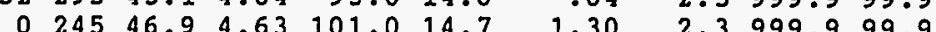
$690901.30 \quad 2.399 .999 .9$

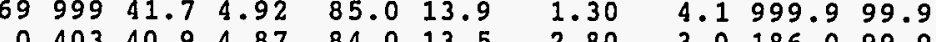

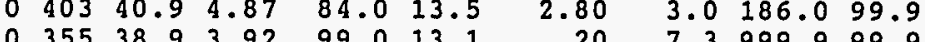

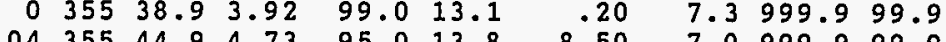
$\begin{array}{llllllllll}104 & 355 & 44.9 & 4.73 & 95.0 & 13.8 & 8.50 & 7.0 & 999.9 & 99.9\end{array}$ $\begin{array}{llllllllll}0 & 295 & 44.3 & 5.70 & 78.0 & 13.4 & 7.90 & 5.4 & 999.9 & 99.9\end{array}$ $\begin{array}{llllllllll}0 & 213 & 38.5 & 4.22 & 91.0 & 12.8 & .09 & 12.3 & 999.9 & 99.9\end{array}$ $\begin{array}{llllllllll}0 & 275 & 43.0 & 4.78 & 90.0 & 13.8 & 3.40 & 20.6 & 999.9 & 99.9\end{array}$ $\begin{array}{llllllllll}0 & 358 & 43.2 & 5.65 & 76.0 & 14.0 & 7.00 & 5.3 & 999.9 & 99.9\end{array}$ $\begin{array}{llllllllll}0 & 220 & 47.8 & 5.57 & 86.0 & 15.8 & .10 & 4.9 & 999.9 & 99.9\end{array}$

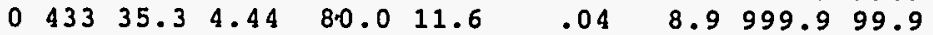

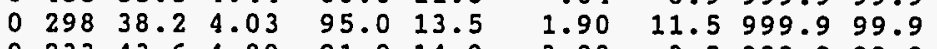

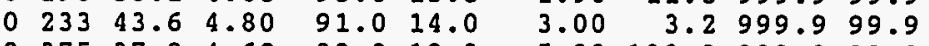

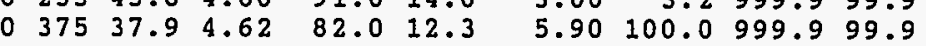

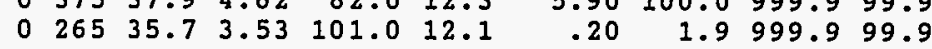

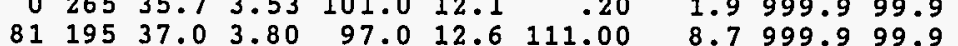

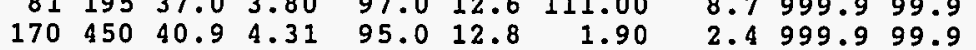
$\begin{array}{llllllllll}0 & 405 & 45.0 & 4.59 & 98.0 & 12.8 & 1.90 & 2.4 & 999.9 & 99.9 \\ 0 & 205 & 41.2 & 4.35 & 95.0 & 14.2 & 2.80 & 7.7 & 999.9 & 99.9\end{array}$

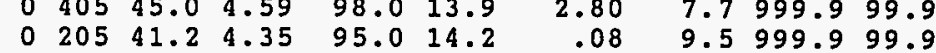

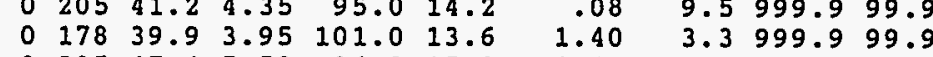
$\begin{array}{lllllllll}0 & 285 & 47.4 & 5.53 & 86.0 & 15.0 & 2.40 & 5.1999 .9 & 99.9\end{array}$ $\begin{array}{llllllllll}186 & 325 & 36.5 & 3.69 & 99.0 & 12.7 & .10 & 7.4 & 125.0 & 99.9\end{array}$

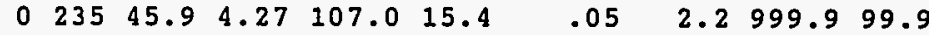

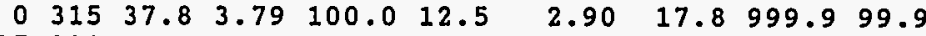

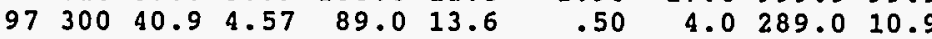

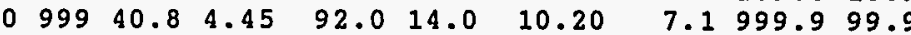
$\begin{array}{llllllllll}0 & 324 & 46.5 & 5.25 & 89.0 & 15.1 & 8.50 & 10.9 & 399.0 & 13.4\end{array}$ $\begin{array}{lllllllll}66 & 295 & 44.4 & 4.80 & 92.0 & 14.3 & 0.00 & 7.9 & 999\end{array}$

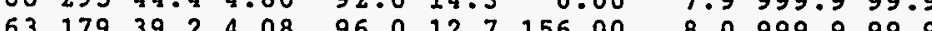

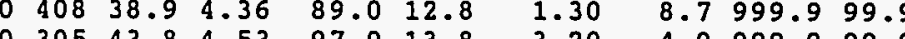

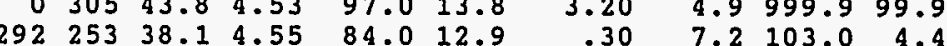
$\begin{array}{rrrrrrrrrr}92 & 253 & 38.1 & 4.55 & 84.0 & 12.9 & .30 & 7.2 & 103.0 & 4.4 \\ 0 & 340 & 36.1 & 3.78 & 96.0 & 11.3 & 3.70 & 3.6 & 98.0 & 99.9\end{array}$ $\begin{array}{rrllllllll}0 & 340 & 36.1 & 3.78 & 96.0 & 11.3 & 3.70 & 3.6 & 98.0 & 99.9 \\ 0 & 615 & 40.3 & 4.59 & 88.0 & 13.3 & 0.00 & 8.0 & 999.9 & 99.9\end{array}$

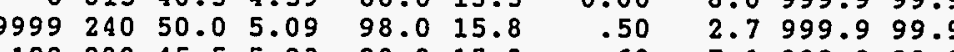
$\begin{array}{lllllllll}128 & 280 & 45.5 & 5.03 & 90.0 & 15.8 & .60 & 7.1999 .9 & 99.9\end{array}$

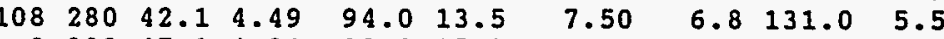
$\begin{array}{llllllllll}0 & 308 & 47.1 & 4.81 & 98.0 & 15.2 & 3.60 & 11.0 & 999.9 & 99.9\end{array}$

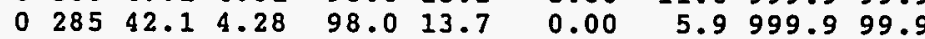

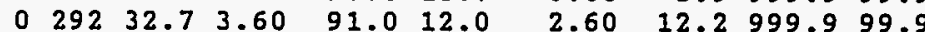
$\begin{array}{llllllllll}0 & 290 & 52.0 & 5.09 & 102.0 & 17.1 & 0.00 & 12.3 & 97.0 & 99.9\end{array}$ $\begin{array}{lllllllll}0 & 308 & 50.3 & 5.34 & 94.0 & 16.0 & 2.70 & 3.9 & 999.9\end{array}$

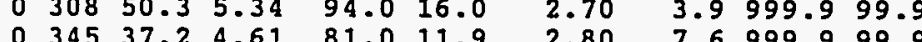
$003450.24 .61 \quad 81.016 .0 \quad 2.80 \quad 7.699 .999 .9$

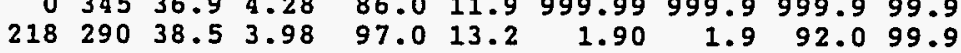

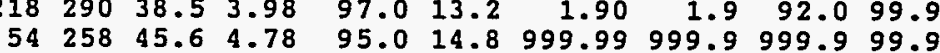

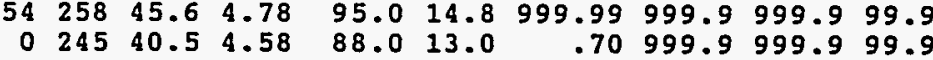


COMPUTER IISTING OF 1988 RAW DATA

EOS

$\begin{array}{rrrrrrrr}59 & 1711 & 531 & 118 & 0 & 245 & 45.3 & 4.97 \\ 0 & 2880 & 450 & 3510 & 0 & 325 & 49.5 & 5.11 \\ 156 & 2964 & 234 & 390 & 0 & 330 & 39.2 & 4.74 \\ 55 & 880 & 330 & 825 & 110 & 240 & 36.2 & 3.93 \\ 79 & 2212 & 553 & 474 & 0 & 315 & 47.8 & 4.95 \\ 0 & 2080 & 52 & 0 & 0 & 373 & 38.6 & 4.11 \\ 59 & 1593 & 59 & 2124 & 59 & 288 & 40.2 & 4.17 \\ 0 & 3852 & 749 & 749 & 0 & 278 & 51.9 & 5.68 \\ 71 & 2627 & 0 & 142 & 0 & 300 & 40.0 & 4.95 \\ 92 & 1656 & 92 & 46 & 0 & 255 & 47.2 & 5.62 \\ 0 & 2739 & 498 & 332 & 249 & 390 & 45.2 & 4.99 \\ 77 & 3311 & 539 & 308 & 0 & 220 & 41.2 & 4.41 \\ 0 & 4300 & 258 & 774 & 0 & 324 & 47.4 & 5.96 \\ 0 & 2144 & 268 & 402 & 0 & 403 & 38.5 & 4.15 \\ 73 & 3066 & 1168 & 219 & 0 & 243 & 39.3 & 3.95\end{array}$

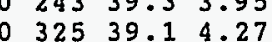

$\begin{array}{lllll}136 & 158 & 45.9 & 5.14\end{array}$

$\begin{array}{llll}210 & 325 & 42.9 & 4.41\end{array}$

0
0

$80 \quad 355 \quad 42.0 \quad 4.76$

022548.05 .24

$\begin{array}{llll}124 & 280 & 45.9 & 5.32\end{array}$

$\begin{array}{llll}0 & 202 & 42.5 & 4.12\end{array}$ $\begin{array}{rrrr}100 & 158 & 38.1 & 4.16 \\ 0 & 470 & 39.3 & 4.31\end{array}$

$\begin{array}{llll}0 & 350 & 41.9 & 4.54\end{array}$

$\begin{array}{llll}102 & 290 & 40.8 & 4.56\end{array}$

$\begin{array}{llll}101 & 340 & 42.9 & 5.03 \\ 291 & 220 & 38.6 & 4.29\end{array}$

$\begin{array}{rrrr}291 & 220 & 38.6 & 4.29 \\ 87 & 310 & 45.9 & 5.05\end{array}$

$0 \quad 240 \quad 47.6 \quad 4.91$

$\begin{array}{lllll}291 & 458 & 40.5 & 4.74\end{array}$

$\begin{array}{llll}81 & 178 & 46.0 & 5.33\end{array}$

$900410036.9 \quad 3.93$

$025040.6 \quad 4.57$

$8133051.9 \quad 5.64$

$\begin{array}{llll}83 & 428 & 39.8 & 4.12\end{array}$

$\begin{array}{llll}0 & 280 & 38.6 & 4.03\end{array}$

$83 \quad 310 \quad 44.2 \quad 5.18$

$\begin{array}{llll}0 & 235 & 35.0 & 3.67\end{array}$

$\begin{array}{llll}126 & 265 & 40.4 & 4.49\end{array}$

$\begin{array}{lllll}90 & 355 & 41.6 & 4.74\end{array}$

$\begin{array}{llll}0 & 225 & 44.5 & 4.74\end{array}$ $\begin{array}{lllll}0 & 455 & 38.0 & 4.39\end{array}$ $\begin{array}{lllll}128 & 150 & 42.6 & 4.39\end{array}$ $81310 \quad 45.9 \quad 5.05$ $\begin{array}{lllll}62 & 290 & 42.9 & 4.85\end{array}$

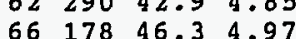
$\begin{array}{lllll}128 & 350 & 43.4 & 5.02\end{array}$

$\begin{array}{llll}0 & 318 & 40.0 & 5.06\end{array}$
MCV HGB TSH PRL FBS HBAIC $\begin{array}{llllll}91.0 & 13.9 & 0.00 & 999.9 & 103.0 & 4.6\end{array}$ $\begin{array}{lllllll}97.0 & 15.9 & 999.99 & 999.9 & 999.9 & 99.9\end{array}$ $\begin{array}{lllllll}83.0 & 12.8 & 999.99 & 999.9 & 999.9 & 99.9\end{array}$

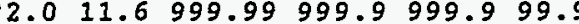

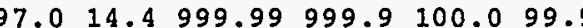

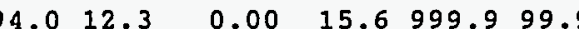

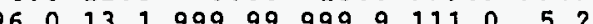
(1.0 17.0 . (1.0 13.2 . 0 . (1) (9. (. 9. (9.9. $\begin{array}{llllll}8.0 & 12.7 & .70 & 999.9 & 141.0 & 6.5\end{array}$

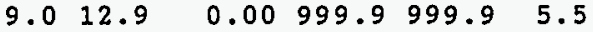
$\begin{array}{lllllll}2.0 & 12.9 & 999.99 & 999.9 & 999.9 & 99.9\end{array}$ $\begin{array}{llllll}0 & 14.2 & 999.99 & 999.9 & 999.9 & 99.9\end{array}$ $\begin{array}{lllllll}9.0 & 12.9 & 999.99 & 999.9 & 238.0 & 8.0\end{array}$ $\begin{array}{llllll}96.0 & 14.1 & 999.99 & 999.9 & 999.9 & 99.9\end{array}$ $\begin{array}{lllllll}91.0 & 15.6 & 0.00 & 999.9 & 396.0 & 7.6\end{array}$ $\begin{array}{lllllll}88.0 & 13.7 & 999.99 & 999.9 & 999.9 & 99.9\end{array}$ 2. 015.7 999.99 999.9141 .098

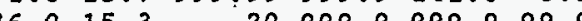
و و 9. . (2.

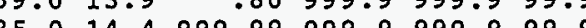
$\begin{array}{llllll}8.0 & 14.4 & 999.99 & 999.9 & 999.9 & 99.9\end{array}$ 90.0 $12.4999 .99,999.9999 .999 .9$ $\begin{array}{lllllll} & 1.0 & 14.6 & 999.99 & 999.9 & 184.0 & 8.0\end{array}$ $\begin{array}{llllll}97.0 & 15.5 & 999.99 & 999.9 & 158.0 & 99.9\end{array}$ $\begin{array}{lllllll}85.0 & 13.0 & 999.99 & 999.9 & 999.9 & 99.9\end{array}$ $\begin{array}{lllllll}86.0 & 14.9 & 999.99 & 999.9 & 999.9 & 99.9\end{array}$

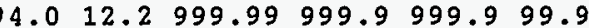
$\begin{array}{llllll}86.0 & 12.2 & 999.99 & 999.9 & 999.9 & 7.0\end{array}$ $89.0 \quad 13.3 \quad 2.10 \quad 999.9 \quad 999.9 \quad 99.9$ 92.015 .8999 .993 .0115 .00 .3

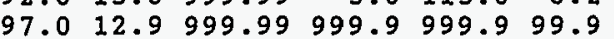

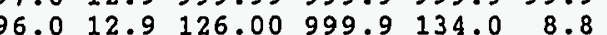
$94.0 \quad 15.1999 .99999 .9999 .999 .9$ $85.0 .15 .0 \quad 1.60999 .9999 .999 .9$ $95.012 .5 \quad 999.99999 .9999 .999 .9$ $91.013 .1999 .99999 .9220 .0 \quad 8.4$ $\begin{array}{llllll}88.0 & 13.6 & 2.40 & 999.9 & 999.9 & 99.9\end{array}$ $\begin{array}{llllll}94.0 & 13.7 & 999.99 & 999.9 & 999.9 & 99.9\end{array}$ $\begin{array}{llllll}87.0 & 12.3 & 999.99 & 999.9 & 215.0 & 11.5\end{array}$ $\begin{array}{llllll}97.0 & 13.5 & 999.99 & 999.9 & 999.9 & 99.9\end{array}$ $\begin{array}{llllll}91.0 & 14.6 & 999.99 & 999.9 & 999.9 & 99.9\end{array}$ $\begin{array}{llllll}89.0 & 13.9 & 999.99 & 999.9 & 260.0 & 10.5\end{array}$ $\begin{array}{llllll}88.0 & 14.0 & 1.00 & 999.9 & 999.9 & 99.9\end{array}$ $93.0 \quad 15.8 \quad 999.99999 .9 \quad 999.999 .9$ $\begin{array}{llllll}86.0 & 14.7 & 999.99 & 999.9 & 322.0 & 10.3\end{array}$ 
COMPUTER IISTING OF 1988 RAW DATA

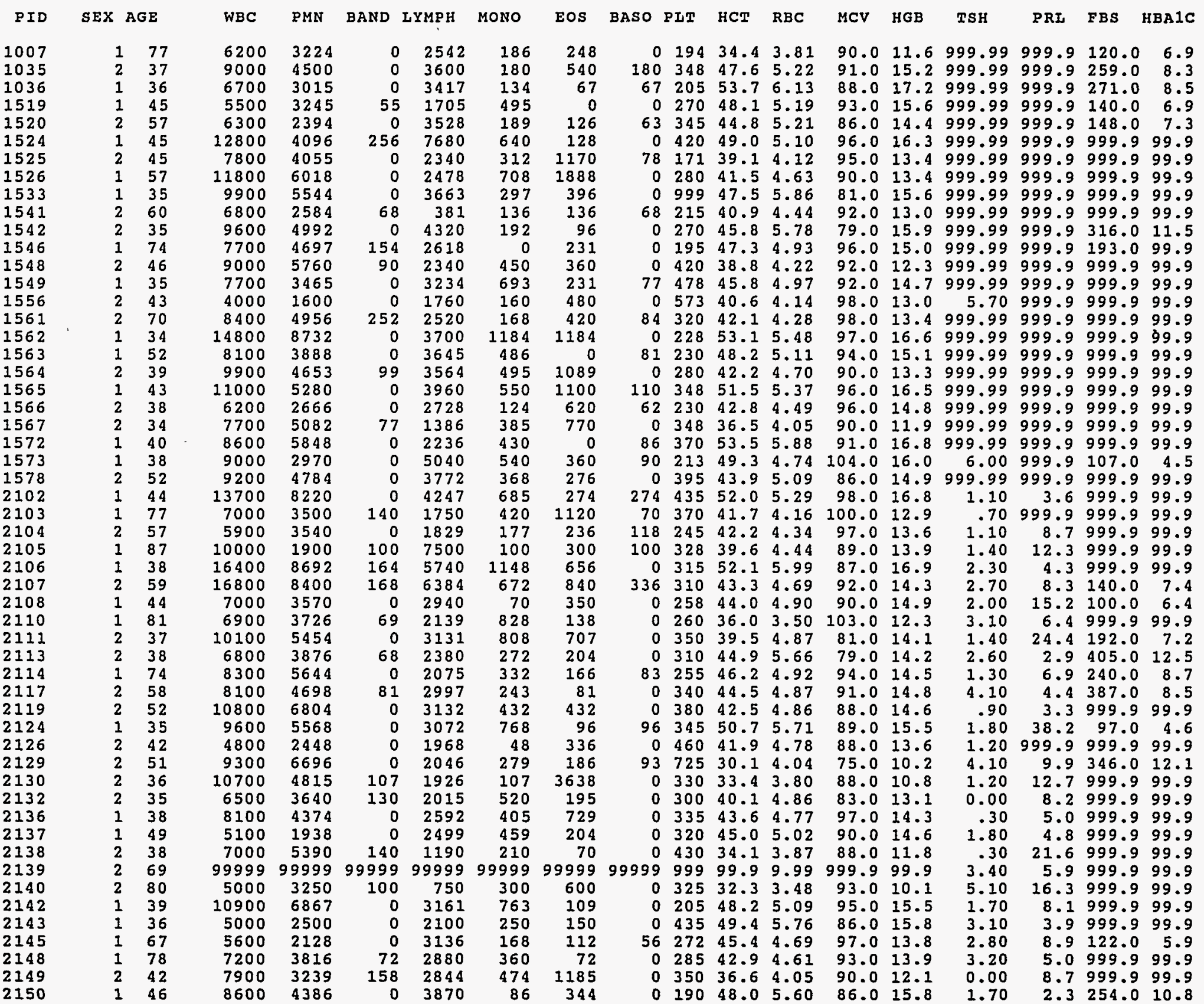


COMPUTER IISTING OF 1988 RAW DATA

\begin{tabular}{|c|c|c|}
\hline PID & SEX & AGE \\
\hline 2152 & 1 & 51 \\
\hline 2153 & 1 & 35 \\
\hline 2155 & 1 & 34 \\
\hline 2156 & 1 & 43 \\
\hline 2158 & 2 & 63 \\
\hline 2160 & 2 & 38 \\
\hline 2166 & 1 & 71 \\
\hline 2167 & 1 & 48 \\
\hline 2171 & 2 & 36 \\
\hline 2172 & 2 & 46 \\
\hline 2174 & 1 & 34 \\
\hline 2176 & 1 & 44 \\
\hline 2179 & 1 & 37 \\
\hline 2182 & 2 & 86 \\
\hline 2188 & 3 & 36 \\
\hline 2193 & & 65 \\
\hline 2195 & 2 & 58 \\
\hline 2196 & & 72 \\
\hline 2197 & 2 & 35 \\
\hline 2205 & & 63 \\
\hline 2206 & 1 & 66 \\
\hline 2207 & 1 & 39 \\
\hline 2208 & 2 & 71 \\
\hline 2209 & 2 & 39 \\
\hline 2210 & & 34 \\
\hline 2215 & 2 & 67 \\
\hline 2216 & & 68 \\
\hline 2217 & 2 & 55 \\
\hline 2220 & & 59 \\
\hline 2224 & 2 & 65 \\
\hline 2226 & 2 & 36 \\
\hline 2227 & & 38 \\
\hline 2228 & 2 & 42 \\
\hline 2229 & & 52 \\
\hline 2230 & 2 & 46 \\
\hline 2231 & & 35 \\
\hline 2232 & . & 36 \\
\hline 2233 & I & 36 \\
\hline 2234 & & 46 \\
\hline 2235 & & 41 \\
\hline 2236 & & 45 \\
\hline 2237 & & 41 \\
\hline 2239 & & 37 \\
\hline 2244 & & 78 \\
\hline 2247 & & 42 \\
\hline 2248 & & 49 \\
\hline 2251 & & 39 \\
\hline 2254 & & 38 \\
\hline 2256 & & 39 \\
\hline 2257 & & 41 \\
\hline 2260 & & 34 \\
\hline 2261 & & 59 \\
\hline 2268 & & 33 \\
\hline 2269 & & \\
\hline
\end{tabular}

WBC PMN BAND IYMPH MONO

$\begin{array}{rrrrr}9900 & 4950 & 198 & 3861 & 396 \\ 7500 & 4050 & 75 & 2625 & 525 \\ 6600 & 3498 & 0 & 2574 & 528 \\ 5200 & 2236 & 208 & 2392 & 260 \\ 6500 & 4225 & 65 & 1625 & 260 \\ 9400 & 3854 & 0 & 4982 & 188 \\ 7600 & 3192 & 228 & 3724 & 228 \\ 7200 & 3168 & 0 & 3384 & 432 \\ 8700 & 4089 & 0 & 4002 & 348 \\ 7700 & 4543 & 0 & 2002 & 770 \\ 9000 & 5850 & 0 & 2160 & 540 \\ 5600 & 3080 & 0 & 2240 & 112 \\ 10100 & 5757 & 101 & 3333 & 303\end{array}$

$4800 \quad 2304$

9999999999

$4900 \quad 2548$

$7200 \quad 4392$

$8400-5628$

$7900 \quad 3713$

$6300 \quad 3591$

$5500 \quad 1870$

$9800 \quad 6566$

$9700 \quad 4753$

$6800 \quad 2992$

$10400 \quad 6340$

$9600 \quad 5184$

$9100 \quad 4732$

$7100 \quad 454$

$8000 \quad 5360$

9999999999

$11600 \quad 8468$

$11100 \quad 7548$

$7900 \quad 3713$

$7300 \quad 4526$

$9400 \quad 3854$

$6700 \quad 3483$

$8000 \quad 4400$

$7100 \quad 4047$

$6000 \quad 2520$

$8300 \quad 3569$

$\begin{array}{ll}8400 & 5292 \\ 5600 & 1232\end{array}$

$\begin{array}{ll}5600 & 1232 \\ 7400 & 3996\end{array}$

$\begin{array}{ll}7400 & 3996 \\ 10100 & 6767\end{array}$

$10100 \quad 6767$

$8000 \quad 4480$

8100
$5800 \quad 2979$

$7400 \quad 4662$

$6000 \quad 2820$

$5000 \quad 2900$

$9700 \quad 3783$

$9600 \quad 5952$ 02088 $\begin{array}{ll}49 & 1813 \\ 72 & 2304\end{array}$ 02604 $84 \quad 1932$ $0 \quad 3634$

$63 \quad 2142$

0.3245

2842

3492

2516

2700
3744

$0 \quad 2912$

$\begin{array}{rr}0 & 2912 \\ 71 & 1917\end{array}$

01920

168

395

189 320

0
7953

$\begin{array}{rr}79 & 3002 \\ 0 & 2263\end{array}$

$78 \quad 3276$

$0 \quad 4324$

o 2948

$0 \quad 3040$

0
6 2627

60
0
0

$0 \quad 2184$

0
0

$74 \quad 2516$

0 2424

02880

$0 \quad 2320$

$74 \quad 2368$

0
0
1900

$291 \quad 4171$
96
2784
EOS BASO PLT HCT RBC MCV HGB

$\begin{array}{llllll}0 & 325 & 46.4 & 4.90 & 95.0 & 15.4\end{array}$ $\begin{array}{lllllll}75 & 220 & 41.4 & 4.94 & 84.0 & 13.7\end{array}$ $\begin{array}{lllllll}0 & 355 & 49.3 & 5.97 & 83.0 & 16.5\end{array}$ $\begin{array}{llllll}2 & 350 & 53.3 & 5.50 & 97.0 & 17.0 \\ 0 & 385 & 39.1 & 4.37 & 89.0 & 12.8\end{array}$ $\begin{array}{llllllll}0 & 340 & 47.3 & 5.38 & 88.0 & 15.6\end{array}$ $0 \quad 21045.0 \quad 4.79 \cdot 94.014 .5$ 041043.54 .8190 .014 .8 024043.54 .8190 .014 .8 0 320 42.64 .9187 .013 .9 040042.94 .6492 .014 .2 $0280 \quad 48.95 .4490 .015 .9$ $\begin{array}{llllll}112 & 285 & 47.5 & 5.00 & 94.0 & 15.5\end{array}$ $\begin{array}{llllll}0 & 255 & 52.7 & 6.20 & 85.0 & 16.8\end{array}$ $\begin{array}{lllllll}96 & 375 & 37.3 & 4.02 & 93.0 & 12.2\end{array}$ $96 \quad 144$ 99999999999999999

$\begin{array}{ll}343 & 147 \\ 216 & 216\end{array}$

$216 \quad 216$

248
588
158
315

315

165

$582 \quad 679$

$748 \quad 544$

$7592 \quad 6448$ $182 \quad 1183$ $\begin{array}{ll}71 & 355\end{array}$

$\begin{array}{rrrr}0 & 2552 & 348 & 116\end{array}$ $\begin{array}{rrrrrr}999 & 999 & 99.9 & 9.99 & 999.9 & 99.9 \\ 0 & 205 & 38.7 & 4.20 & 92.0 & 12.7\end{array}$

$\begin{array}{llllll}0 & 360 & 40.0 & 4.86 & 82.0 & 13.2\end{array}$

$\begin{array}{lllllll}0 & 263 & 37.4 & 4.08 & 92.0 & 12.3\end{array}$

$\begin{array}{llllll}0 & 390 & 34.7 & 3.80 & 91.0 & 11.5\end{array}$

$\begin{array}{lllllll}0 & 250 & 43.2 & 5.34 & 81.0 & 14.8 \\ 0 & 300 & 47.7 & 5.20 & 92.0 & 14.9\end{array}$

$110 \quad 305 \quad 44.7 \quad 5.18 \quad 86.0 \quad 14.6$

$038540.7 \quad 4.48 \quad 91.0013 .4$

$\begin{array}{lllllll}0 & 260 & 45.0 & 4.96 & 91.0 & 14.2\end{array}$

$\begin{array}{lllllll}0 & 280 & 42.7 & 4.77 & 90.0 & 13.2\end{array}$

$\begin{array}{llllll}0 & 485 & 44.4 & 5.16 & 86.0 & 13.8\end{array}$

$\begin{array}{lllllll}91 & 365 & 38.9 & 4.11 & 95.0 & 12.8\end{array}$ $\begin{array}{rrrrrr}142 & 322 & 40.3 & 4.20 & 96.0 & 13.1 \\ 0 & 370 & 34.9 & 3.61 & 97.0 & 11.7\end{array}$ $\begin{array}{rrrrrr}0 & 370 & 34.9 & 3.61 & 97.0 & 11.7\end{array}$

$\begin{array}{rrrrrr}116 & 423 & 36.1 & 4.25 & 85.0 & 11.7\end{array}$ $\begin{array}{lllllll}158 & 260 & 42.7 & 4.86 & 88.0 & 14.2\end{array}$ $\begin{array}{lllllll}0 & 650 & 45.1 & 5.48 & 82.0 & 14.9\end{array}$ $\begin{array}{llllll}188 & 235 & 53.5 & 5.46 & 98.0 & 16.9\end{array}$ $\begin{array}{llllllll}0 & 385 & 47.4 & 5.29 & 90.0 & 15.5\end{array}$ $\begin{array}{llllll}71 & 255 & 47.3 & 5.12 & 92.0 & 14.7\end{array}$ $\begin{array}{lllllll}0 & 365 & 40.1 & 4.64 & 86.0 & 14.3\end{array}$

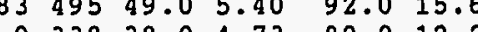
$\begin{array}{rrrrrr}0 & 338 & 38.0 & 4.73 & 80.0 & 12.2\end{array}$ $\begin{array}{rrrrrrr}56 & 205 & 37.2 & 3.71 & 100.0 & 12.4 \\ 0 & 355 & 35.0 & 3.74 & 94.0 & 11.3\end{array}$ $\begin{array}{llllll}0 & 355 & 35.0 & 3.74 & 94.0 & 11.3\end{array}$ $\begin{array}{rrrrrrr}0 & 340 & 41.1 & 4.78 & 86.0 & 13.4 \\ 40 & 360 & 37.1 & 4.79 & 77.0 & 12.3\end{array}$ $\begin{array}{lllllll}240 & 360 & 37.1 & 4.79 & 77.0 & 12.3 \\ 0 & 425 & 38.2 & 4.44 & 86.0 & 13.2\end{array}$ $\begin{array}{lllllll}0 & 425 & 38.2 & 4.44 & 86.0 & 13.2 \\ 0 & 250 & 42.3 & 4.77 & 89.0 & 13.2\end{array}$

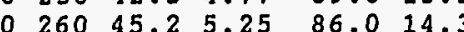
$\begin{array}{lllllll}120 & 458 & 40.5 & 4.48 & 90.0 & 13.0\end{array}$ $\begin{array}{lllllll}0 & 257 & 48.0 & 5.13 & 94.0 & 16.4\end{array}$ $\begin{array}{llllll}194 & 260 & 51.3 & 5.81 & 88.0 & 16.2\end{array}$ $\begin{array}{llllll}194 & 365 & 39.5 & 4.43 & 89.0 & 12.5\end{array}$

$\begin{array}{llllll}222 & 360 & 41.3 & 4.65 & 89.0 & 13.5\end{array}$ $\begin{array}{lllllll}0 & 420 & 43.6 & 5.23 & 83.0 & 14.3\end{array}$ $\begin{array}{llllll}0 & 271 & 50.2 & 5.47 & 92.0 & 16.2\end{array}$
TSH PRL FBS HBAIC

$0.00 \quad 7.9 \quad 117.099 .9$

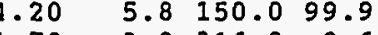
$\begin{array}{llll}3.9 & 316.0 & 9.6\end{array}$ $2.50 \quad 5.9999 .999 .9$ $\begin{array}{llll}0.00 & 4.9 & 276.0 & 8.1\end{array}$ $4.70 \quad 7.5 \quad 999.999 .9$ $1.00 \quad 7.6999 .999 .9$ $.20 \quad 7.9217 .099 .9$ .0414 .6237 .008 .04
2.60 $\quad 4.4 \quad 999.9 \quad 99.9$ $1.20999 .9264 .0 \quad 10.8$

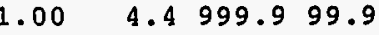
$\begin{array}{llll}3.20 & 32.8 & 108.0 & 4.7\end{array}$ $2.50 \quad 7.3999 .999 .9$ $1.30 \quad 6.2999 .999 .9$ $.20 \quad 6.0 \quad 999.9 \quad 99.9$ $.90 \quad 8.7 \quad 999.9 \quad 99.9$ $1.00 \quad 5.0 \quad 192.0 \quad 8.4$ $1.10 \quad 3.2 \quad 197.0 \quad 8.2$ $\begin{array}{rrrr}.90 & 7.5 & 177.0 & 6.5\end{array}$ $1.50 \quad 10.9$ 96.0 99.9 $0.00 \quad 4.3162 .010 .2$ $\begin{array}{llll}1.70 & 17.3 & 264.0 & 7.9\end{array}$ $2.20 \quad 11.0 \quad 999.9 \quad 99.9$

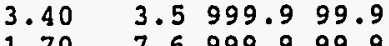
$\begin{array}{llll}1.70 & 7.6 & 999.9 & 99.9\end{array}$ $2.20 \quad 12.5 .999 .9 \quad 99.9$ $\begin{array}{llll}1.00 & 43.7 & 999.9 & 99.9\end{array}$ $\begin{array}{llll}1.40 & 12.7 & 999.9 & 99.9\end{array}$ $\begin{array}{lllll}0.00 & 6.0 & 999.9 & 99.9\end{array}$

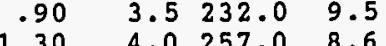
$6.20 \quad 6.4 \quad 999.999 .9$ $2.80 \quad 2.0999 .999 .9$ $2.60 \quad 8.5999 .999 .9$

$.80 \quad 6.4999 .999 .9$

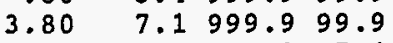
$\begin{array}{llll}1.70 & 4.0 & 999.9 & 7.6\end{array}$

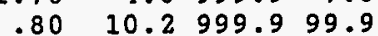
$3.40 \quad 13.1 \quad 155.0 \quad 7.1$ $.70 \quad 11.2999 .999 .9$ 0.00 $\begin{array}{rrrr}9.40 & 26.9 & 999.9 & 99.9 \\ 3.60 & 9.0 & 999.9 & 99.9\end{array}$ $\begin{array}{llll}3.60 & 9.0 & 999.9 & 99.9\end{array}$ $\begin{array}{llll}.40 & 4.2 & 391.0 & 13.3\end{array}$ $70 \quad 60.2 \quad 99.0 \quad 5.3$
.89 $2.80 \quad 16.1999 .999 .9$ $\begin{array}{llll}2.20 & 6.8 & 130.0 & 4.8\end{array}$ $2.00 \quad 4.1999 .999 .9$ 
COMPUTER IISTING OF 1988 RAW DATA

\begin{tabular}{|c|c|c|c|c|c|c|c|c|c|c|c|c|c|c|c|c|c|}
\hline ID & SEX AGE & WBC & PMN & BAND & IYMPH & MONO & EOS & BASO & $\mathrm{pLT}$ & HCT & RBC & MCV & HGB & TSH & PRI & FBS & HBA \\
\hline & $\begin{array}{l}33 \\
33 \\
34\end{array}$ & $\begin{array}{l}8500 \\
7600 \\
8400\end{array}$ & $\begin{array}{l}2805 \\
3572 \\
5040\end{array}$ & 0 & $\begin{array}{l}3910 \\
3192 \\
2772\end{array}$ & $\begin{array}{l}255 \\
304 \\
420\end{array}$ & $\begin{array}{r}1275 \\
532 \\
168\end{array}$ & $\begin{array}{r}255 \\
0 \\
0\end{array}$ & $\begin{array}{l}305 \\
225 \\
199\end{array}$ & $\begin{array}{l}48.6 \\
48.4 \\
28.1\end{array}$ & $\begin{array}{l}5.35 \\
5.54 \\
4.71\end{array}$ & $\begin{array}{l}91.0 \\
87.0 \\
60.0\end{array}$ & $\begin{array}{r}15.7 \\
15.2 \\
9.5\end{array}$ & $\begin{array}{l}2.60 \\
2.40 \\
1.20\end{array}$ & $\begin{array}{r}4.1 \\
3.6 \\
24.3\end{array}$ & $\begin{array}{l}245.0 \\
999.9 \\
999.9\end{array}$ & \\
\hline
\end{tabular}


COMPUTER IISTING OF 1989 RAW DATA

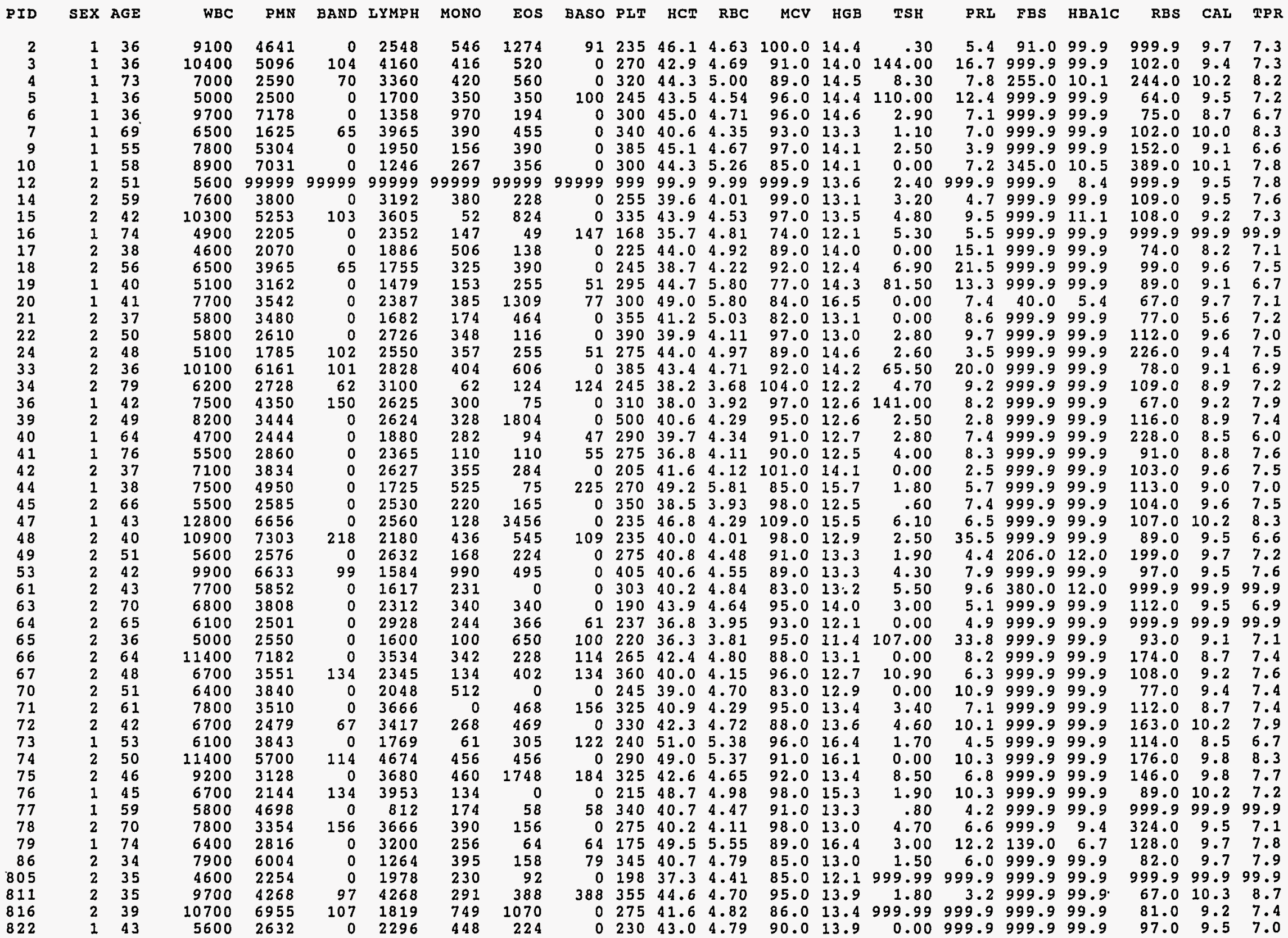


COMPUTER IISTING OF 1989 RAW DATA

WBC

PMN BAND LYMPH MONO

$\begin{array}{lll}78 & 1872 & 546\end{array}$

546
249

546
83

$\begin{array}{rrrrrr}3700 & 1295 & 555 & 925 & 407 & 407 \\ 99999 & 99999 & 99999 & 99999 & 99999 & 99999 \\ 6300 & 2583 & 0 & 1827 & 63 & 1764\end{array}$

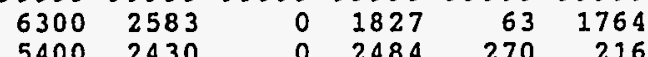

$\begin{array}{rrrrrr}5400 & 2430 & 0 & 2484 & 270 & 216 \\ 3700 & 1295 & 0 & 2072 & 185 & 37\end{array}$

1295

$12400 \quad 6324$

$9200 \quad 3036$

$6100 \quad 2684$

$6200 \quad 3100$

$11300 \quad 8927$

$8900 \quad 6052$

$11900 \quad 6664$

$6000 \quad 1860$

$\begin{array}{rr}11500 & 3795 \\ 6700 & 3484\end{array}$

$\begin{array}{rr}6700 & 3484 \\ 7800 & 5070\end{array}$

$\begin{array}{ll}7800 & 5070 \\ 5500 & 3300\end{array}$

$6800 \quad 3332$

$7500 \quad 4800$
$6400 \quad 3776$

$6400 \quad 3776$

$7100 \quad 3905$

$5200 \quad 2288$

$5700 \quad 2850$

$\begin{array}{ll}8100 & 3564 \\ 6300 & 3087\end{array}$

$8800 \quad 5016$

$6900 \quad 3243$

9000
8100
6310
6009

60003000

$7300 \quad 3650$

$7800 \quad 4680$

$4900 \quad 2107$

$5100 \quad 1989$

$7300 \quad 4161$

$4500 \quad 2745$

$8000 \quad 4880$

$\begin{array}{ll}6900 & 3726 \\ 7000 & 4200\end{array}$

$\begin{array}{ll}7000 & 4200 \\ 7700 & 4543\end{array}$

$5200 \quad 2652$

$6600 \quad 2706$

$4100 \quad 2255$

6400
6800 2726

$7000 \quad 3290$

$8500 \quad 4930$

$6700 \quad 4422$

8100
$10800 \quad 5400$
44960

03840

0
0
0 3496

$0 \quad 2356$

001695

89
0
0 2856

02856

$115 \quad 5635$

$134 \quad 2747$

$156 \quad 2106$

001650

$75 \quad 2250$

$0 \quad 1728$

$0 \quad 2130$

$\begin{array}{ll}0 & 2028 \\ 0 & 2109\end{array}$

022109

0 3726

02024

0255

0

$0 \quad 2460$

0
78 139

$\begin{array}{ll}78 & 2418 \\ 89 & 3738\end{array}$

$0 \quad 1176$

$0 \quad 2550$

$0 \quad 2117$

- 1440

0
69 2640

$\begin{array}{rr}69 & 2484 \\ 0 & 2380\end{array}$

$\begin{array}{ll}0 & 2380 \\ 0 & 2695\end{array}$

$0 \quad 1768$

$66 \quad 2376$

821271

2368
$0 \quad 3264$

$\begin{array}{ll}0 & 3264 \\ 0 & 3010\end{array}$

0
0 2720

0 1675

$\begin{array}{rr}0 & 2997 \\ 648 & 3240\end{array}$ $\begin{array}{rr}185 & 37 \\ 124 & 744\end{array}$

$672 \quad 288$

$552 \quad 1932$

$339 \quad 226$

$\begin{array}{ll}339 & 226 \\ 356 & 267\end{array}$

$357 \quad 1785$

$\begin{array}{rr}540 & 480 \\ 230 & 1725\end{array}$

0268

$\begin{array}{rr}390 & 78 \\ 275 & 220\end{array}$

$\begin{array}{ll}275 & 220 \\ 408 & 340\end{array}$

300

128

355

312

342
405
189

189

1056
621

540

240

219

89

490
357

73
135

400

414

231

364
$183 \quad 854$

BASO PIT HCT RBC

\begin{abstract}
MCV HGB
\end{abstract}
TSH

PRL FBS HBAIC

RBS CAI TPR

$\begin{array}{lllllllllll}34 & 125 & 45.9 & 4.97 & 92.0 & 15.2 & 999.99 & 999.9 & 999.9 & 99.9\end{array}$ $\begin{array}{llllllllll}0 & 300 & 42.1 & 5.09 & 83.0 & 13.4 & 999.99 & 999.9 & 999.9 & 99.9\end{array}$ $\begin{array}{rrrrrrrrrr}0 & 185 & 34.7 & 3.74 & 92.0 & 11.1 & 999.99 & 999.9 & 999.9 & 99.9 \\ 999 & 999 & 99.9 & 9.99 & 999.9 & 99.9 & .10 & 999.9 & 999.9 & 99.9\end{array}$

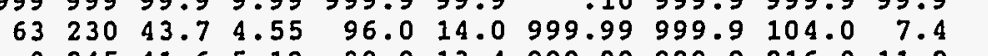
$\begin{array}{llllllllll}0 & 245 & 41.6 & 5.19 & 80.0 & 13.4 & 999.99 & 999.9 & 216.0 & 11.2\end{array}$ $\begin{array}{rrrrrrrrrr}111 & 300 & 44.3 & 5.09 & 87.0 & 14.1 & 999.99 & 999.9 & 999.9 & 99.9 \\ 124 & 305 & 50.2 & 5.18 & 97.0 & 16.4 & 999.99 & 999.9 & 301.0 & 8.7\end{array}$ $\begin{array}{llll}0 & 310 & 52.0 & 5.49\end{array}$ $92305 \quad 48.16 .06$ $6199939.0 \quad 4.33$ $\begin{array}{llll}113 & 315 & 36.5 & 3.93\end{array}$ $\begin{array}{lllll}0 & 225 & 44.6 & 4.99\end{array}$ $\begin{array}{llll}238 & 260 & 34.8 & 3.68\end{array}$ $\begin{array}{lllll}0 & 375 & 40.8 & 4.36\end{array}$ $\begin{array}{rrrrr}0 & 270 & 44.5 & 4.83 \\ 67 & 245 & 43.3 & 4.73\end{array}$

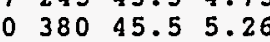
$\begin{array}{lllll}55 & 185 & 44.7 & 5.30\end{array}$ $\begin{array}{llll}0 & 379 & 41.7 & 4.34\end{array}$ $\begin{array}{rrrrr}0 & 280 & 40.2 & 4.52\end{array}$ $\begin{array}{llll}128 & 305 & 40.6 & 4.61\end{array}$ $\begin{array}{llll}1 & 335 & 39.8 & 4.46 \\ 0 & 290 & 44.0 & 5.18\end{array}$

$\begin{array}{llll}0 & 260 & 44.6 & 4.65\end{array}$

$\begin{array}{llll}0 & 385 & 41.0 & 4.48\end{array}$

$\begin{array}{lllll}0 & 250 & 39.6 & 4.54\end{array}$ $\begin{array}{rrrr}88 & 420 & 38.1 & 4.17 \\ 138 & 235 & 40.7 & 4.97\end{array}$ $\begin{array}{lllll}0 & 255 & 43.1 & 4.87\end{array}$ $\begin{array}{llll}0 & 270 & 47.7 & 5.16 \\ 0 & 305 & 38.2 & 4.12\end{array}$ $\begin{array}{rrrr}146 & 395 & 45.3 & 4.98 \\ 78 & 270 & 46.7 & 5.54\end{array}$ $\begin{array}{llll}78 & 270 & 46.7 & 5.54\end{array}$ $\begin{array}{rrrr}178 & 370 & 38.7 & 4.20\end{array}$ $\begin{array}{lllll}98 & 305 & 42.6 & 4.73\end{array}$ $\begin{array}{rrrrr}0 & 370 & 42.0 & 4.56 \\ 73 & 455 & 36.8 & 4.19\end{array}$ $\begin{array}{rlll}73 & 455 & 36.8 & 4.19 \\ 0 & 300 & 42.1 & 4.42\end{array}$ $\begin{array}{llll}0 & 300 & 42.1 & 4.42 \\ 0 & 385 & 46.9 & 5.38\end{array}$ $69 \quad 410 \quad 44.3 \quad 5.16$ $\begin{array}{lllll}70 & 330 & 44.7 & 5.05\end{array}$ $\begin{array}{llll}77 & 280 & 49.8 & 5.31 \\ 52 & 285 & 42.6 & 4.95\end{array}$ $\begin{array}{rrrr}52 & 285 & 42.6 & 4.95 \\ 0 & 345 & 39.2 & 4.87\end{array}$

$\begin{array}{lllll}0 & 345 & 39.2 & 4.87 \\ 0 & 210 & 35.5 & 3.93\end{array}$

$\begin{array}{llll}0 & 290 & 43.5 & 4.87\end{array}$ $\begin{array}{llll}68 & 260 & 50.4 & 5.90\end{array}$ $\begin{array}{llll}70 & 385 & 42.6 & 5.13\end{array}$ $85 \quad 405 \quad 31.0 \quad 3.43$

$0290 \quad 51.05 .56$

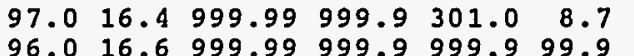
$79.0 \quad 15.8 \quad 999.99 \quad 999.9999 .999 .9$ 90.012 .9 $.10 \quad 9.5257 .0 \quad 7.7$ $96.012 .5 \quad 0.00999 .9999 .999 .9$ $\begin{array}{llllll}93.0 & 11.4 & 999.99 & 999.9 & 999.9 & 99.9 \\ 89.0 & 13.8 & 999.99 & 999.9 & 999.9 & 99.9\end{array}$

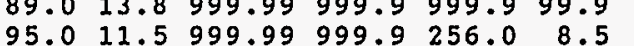
$94.013 .3 \quad 2.20 \quad 999.9 \quad 999.9 \quad 9.9 .9$ $\begin{array}{lllllll}92.0 & 14.5 & .90 & 999.9 & 999.9 & 8.8\end{array}$ $92.0 \quad 13.7 \quad 999.99 \quad 999.9 \quad 999.9 \quad 99.9$ $\begin{array}{rrrrrr}86.0 & 14.6 & 999.99 & 999.9 & 205.0 & 10.5 \\ 84.0 & 14.5 & 999.99 & 999.9 & 135.0 & 7.9\end{array}$ $\begin{array}{rrrrrr}84.0 & 14.5 & 999.99 & 999.9 & 135.0 & 7.9 \\ 96.0 & 13.7 & 999.99 & 999.9 & 999.9 & 99.9\end{array}$ $89.013 .5 \quad 999.99 \quad 999.9 \quad 999.999 .9$ $88.0 \quad 13.1 \quad 999.99 \quad 999.9 \quad 999.999 .9$

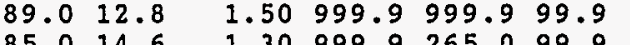

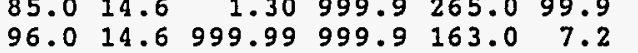
92.013 .9999 .99999 .9999 .999 .9 $\begin{array}{llllll}87.0 & 13.1 & 1.70 & 999.9 & 75.0 & 3.3\end{array}$

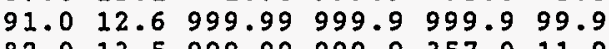
89.013 .5 9 13.990 $92.015 .7 \quad 999.99 \quad 999.9 \quad 999.999 .9$ $\begin{array}{llllll}93.0 & 12.3 & 5.80 & 999.9 & 137.0 & 7.4\end{array}$

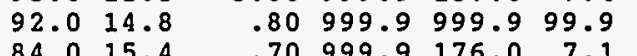

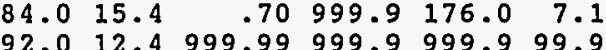
$90.013 .7 \quad 999.99 \quad 999.9304 .0 \quad 12.7$ $\begin{array}{llllll}92.0 & 13.2 & 999.99 & 999.9 & 999.9 & 99.9\end{array}$ $88.0 \quad 12.1 \quad 999.99 \quad 999.9 \quad 231.0 \quad 6.3$ $95.013 .2 \quad 999.99 \quad 999.9 \quad 999.9 \quad 99.9$ $86.014 .5 \quad 3.20999 .9302 .0 \quad 11.0$ $88.014 .1 \quad .90999 .9999 .999 .9$ $\begin{array}{lllllll}94.0 & 15.8 & 999.99 & 999.9 & 999.9 & 99.9\end{array}$ $86.014 .1 \quad 999.99 \quad 999.9296 .0 \quad 10.7$ $\begin{array}{llllll}80.0 & 13.2 & 999.99 & 999.9 & 999.9 & 99.9\end{array}$ $89.011 .8 \quad 0.00 \quad 999.9281 .0 \quad 8.0$ $\begin{array}{llllll}85.0 & 16.8 & 999.99 & 999.9 & 187.0 & 5.9\end{array}$ $\begin{array}{llllll}83.0 & 13.8 & 1.40 & 999.9 & 99.0 & 4.7\end{array}$

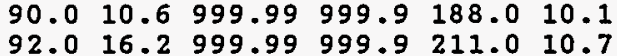

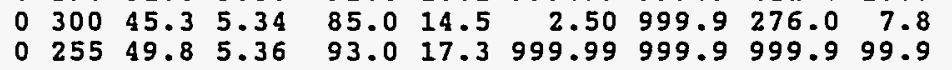

$85.0 \quad 8.9 \quad 7.2$ $84.0 \quad 10.2 \quad 7.9$ $105.09 .3 \quad 7.5$ $\begin{array}{lll}999.9 & 9.7 & 9.1\end{array}$ $\begin{array}{lll}98.0 & 8.8 & 6.8\end{array}$ $212.0 \quad 9.3 \quad 6.9$ $999.999 .9 \quad 99.9$ $999.999 .9 \quad 99.9$ $86.0 \quad 8.97 .0$ $113.0 \quad 9.6 \quad 7.8$ $137.0 \quad 8.96 .5$ $83.0 \quad 9.0 \quad 7.6$ $88.0 \quad 9.5 \quad 7.0$ $254.0 \quad 9.2 \quad 7.1$ $39.0 \quad 9.97 .4$ $99.0 \quad 9.7 \quad 7.8$ $202.0 \quad 9.4 \quad 7.7$ $\begin{array}{lll}126.0 & 9.1 & 7.1\end{array}$ $999.9 \quad 99.9 \quad 99.9$ $156.0 \quad 9.8 \quad 7.4$ $96.0 \quad 9.4 \quad 6.8$ $255.0 \quad 9.8 \quad 8.1$ $\begin{array}{lll}150.0 & 9.4 & 7.9\end{array}$ $110.0 \quad 9.5 \quad 7.5$ $\begin{array}{rrr}73.0 & 8.8 & 6.8\end{array}$ $\begin{array}{llll}389.0 & 10.1 & 7.8\end{array}$ $\begin{array}{rrr}999.9 & 9.5 & 7.9\end{array}$ 
COMPUTER LISTING OF 1989 RAW DATA

1526

1530

1533

1541

1546

1548

1549

1552

1558

1559

1561

1564

1573
1577

1578

2102

2103

2104

2105

2107

2108

2110

2111

2113

2117

2119

2124

2129

2130

2132

2134

2136

2137

2138
2139

2142

2143

2144

2145

2149

2150

2152

2153

2155

2158
WBC PMN BAND LYMPH

$\begin{array}{rrrrrr}13600 & 10336 & 0 & 1904 & 408 & 952 \\ 6300 & 3780 & 63 & 2079 & 126 & 252 \\ 7800 & 3978 & 0 & 2964 & 624 & 234 \\ 6400 & 3648 & 0 & 2368 & 256 & 128 \\ 5900 & 2065 & 0 & 3481 & 177 & 118 \\ 5800 & 2436 & 0 & 2842 & 406 & 116 \\ 10600 & 7102 & 0 & 2650 & 318 & 530 \\ 9900 & 4950 & 99 & 3861 & 495 & 495 \\ 5700 & 2109 & 0 & 2907 & 456 & 171 \\ 7100 & 2556 & 0 & 3550 & 71 & 923 \\ 6100 & 2562 & 0 & 2806 & 305 & 366 \\ 9900 & 6435 & 0 & 3069 & 198 & 198 \\ 6000 & 2580 & 0 & 2760 & 480 & 180 \\ 9000 & 6120 & 0 & 2070 & 180 & 450 \\ 9600 & 4992 & 0 & 2688 & 768 & 1152 \\ 6400 & 3520 & 0 & 2432 & 192 & 256 \\ 9200 & 5704 & 92 & 2852 & 368 & 184 \\ 10000 & 5500 & 100 & 3900 & 200 & 300 \\ 9100 & 4459 & 0 & 3731 & 364 & 455 \\ 9900 & 7227 & 99 & 1683 & 495 & 297 \\ 4300 & 2408 & 0 & 1333 & 172 & 344 \\ 4700 & 2632 & 0 & 1880 & 141 & 47 \\ 10900 & 5668 & 109 & 3052 & 763 & 1308 \\ 10000 & 5100 & 0 & 4600 & 100 & 100 \\ 12300 & 5412 & 0 & 4674 & 861 & 1230 \\ 6200 & 3410 & 0 & 2356 & 248 & 186 \\ 6800 & 3264 & 0 & 2924 & 408 & 136 \\ 8200 & 3854 & 0 & 2460 & 82 & 1558 \\ 6200 & 2914 & 0 & 2542 & 310 & 434 \\ 11400 & 8436 & 114 & 1710 & 570 & 456 \\ 5700 & 1938 & 0 & 3078 & 399 & 228 \\ 14500 & 5655 & 0 & 7540 & 435 & 580 \\ 6500 & 3770 & 65 & 2210 & 325 & 65 \\ 12000 & 7440 & 0 & 3360 & 480 & 600 \\ 10200 & 6222 & 102 & 2652 & 510 & 714 \\ 9200 & 6900 & 0 & 1564 & 368 & 460 \\ 4700 & 3384 & 0 & 846 & 376 & 94 \\ 6400 & 3904 & 0 & 2112 & 192 & 192 \\ 7800 & 3588 & 0 & 3588 & 390 & 234 \\ 4800 & 2208 & 0 & 2112 & 336 & 144 \\ 5800 & 4002 & 0 & 1450 & 290 & 58 \\ 5400 & 2646 & 0 & 1836 & 216 & 702 \\ 6900 & 3726 & 0 & 2484 & 690 & 0 \\ 7000 & 4060 & 0 & 2240 & 350 & 210 \\ 7600 & 4788 & 0 & 2356 & 228 & 228 \\ 7400 & 3774 & 74 & 2516 & 370 & 666 \\ 5700 & 2850 & 57 & 2280 & 285 & 57 \\ 7200 & 3024 & 0 & 2016 & 288 & 2016 \\ 8300 & 5146 & 0 & 2075 & 913 & 166 \\ 7100 & 4260 & 71 & 2059 & 426 & 213 \\ 5000 & 3400 & 0 & 1300 & 150 & 150 \\ 11100 & 5550 & 0 & 4995 & 333 & 0 \\ 4700 & 2820 & 94 & 1222 & 376 & 141 \\ 9100 & 3822 & 91 & 4459 & 728 & 0 \\ & & & & & \end{array}$

OS $B A$

2

34

18

95

23

(6)

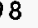

152

256

184
300

455

344

47
308

1308
100
1230

230

136

434

456

228
580

60

28

57

016

166

150

141
0
ASO PLT HCT RBC

$\begin{array}{llll}420 & 35.8 & 4.13\end{array}$

$\begin{array}{llll}245 & 44.1 & 4.95\end{array}$

$\begin{array}{llll}310 & 48.2 & 5.97 \\ 335 & 41.8 & 4.74\end{array}$

$\begin{array}{llll}59 & 355 & 44.1 & 5.54\end{array}$

$\begin{array}{lllll}0 & 121 & 50.2 & 5.40 \\ 0 & 360 & 38.5 & 4.23\end{array}$

$\begin{array}{llll}0 & 385 & 47.3 & 5.37\end{array}$

$\begin{array}{llll}0 & 195 & 40.8 & 4.28\end{array}$

$\begin{array}{llll}61 & 305 & 43.3 & 4.66\end{array}$

$\begin{array}{lllll}0 & 300 & 41.6 & 5.02\end{array}$

$90 \quad 420 \quad 40.7 \quad 4.18$

$\begin{array}{lllll}96 & 405 & 44.0 & 4.87\end{array}$

$\begin{array}{rrrr}0 & 295 & 35.9 & 4.05 \\ 92 & 280 & 51.1 & 5.47\end{array}$

$\begin{array}{lllll}0 & 350 & 40.2 & 4.31\end{array}$

$\begin{array}{lllll}91 & 445 & 42.2 & 5.01 \\ 99 & 260 & 47.5 & 5.11\end{array}$

$43 \quad 355 \quad 45.4 \quad 4.75$

$\begin{array}{lllll}0 & 210 & 41.4 & 4.41\end{array}$

$\begin{array}{lllll}100 & 247 & 45.8 & 5.31\end{array}$

$\begin{array}{lllll}123 & 318 & 45.8 & 5.30\end{array}$

$\begin{array}{llll}0 & 280 & 47.2 & 5.17\end{array}$

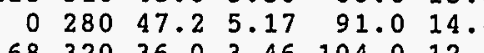

$246505 \quad 40.8 \quad 5.07 \quad 80.0 \quad 13.8$

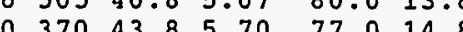

$11437043.8 \quad 5.70 \quad 77.0 \quad 14.8$

$\begin{array}{rrrrrr}144 & 230 & 40.2 & 4.40 & 91.0 & 12.8 \\ 57 & 300 & 45.9 & 5.03 & 91.0 & 14.4\end{array}$

$\begin{array}{lllllll}145 & 305 & 42.7 & 4.86 & 88.0 & 13.8\end{array}$

$\begin{array}{lllllll}65 & 225 & 43.9 & 4.97 & 88.0 & 14.8\end{array}$

$\begin{array}{lllllll}120 & 305 & 41.4 & 4.62 & 90.0 & 13.1\end{array}$

$\begin{array}{lllllll}0 & 495 & 38.0 & 4.85 & 78.0 & 13.4\end{array}$

$030039.24 .86 \quad 81.0 \quad 12.8$

$\begin{array}{lllllll}0 & 345 & 42.1 & 4.91 & 86.0 & 14.0\end{array}$

$\begin{array}{llllll}0 & 355 & 45.0 & 4.74 & 95.0 & 14.2\end{array}$

$\begin{array}{lllllll}0 & 280 & 4.3 & 4.82 & 90.0 & 14.2\end{array}$

$\begin{array}{lllllll}0 & 430 & 37.4 & 4.36 & 86.0 & 12.4\end{array}$

$\begin{array}{lllllll}0 & 310 & 38.9 & 4.13 & 94.0 & 12.8\end{array}$

$140 \quad 310 \quad 47.6 \quad 5.59 \quad 85.0 \quad 15.2$

$\begin{array}{lllllll}0 & 275 & 47.4 & 4.63 & 102.0 & 15.5\end{array}$

$\begin{array}{llllll}0 & 435 & 41.3 & 4.39 & 94.0 & 13.6\end{array}$

$\begin{array}{llllll}171 & 185 & 36.9 & 4.06 & 91.0 & 12.7\end{array}$

$\begin{array}{lllllll}0 & 300 & 35.2 & 3.72 & 95.0 & 11.8\end{array}$

$\begin{array}{llllll}0 & 280 & 48.2 & 5.71 & 84.0 & 15.8\end{array}$

$\begin{array}{llllll}0 & 255 & 41.5 & 5.09 & 82.0 & 13.2\end{array}$

$\begin{array}{llllll}222 & 385 & 56.4 & 6.67 & 85.0 & 18.7\end{array}$

$\begin{array}{rrrrrr}47 & 370 & 52.0 & 5.22 & 98.0 & 17.4 \\ 0 & 380 & 39.8 & 4.44 & 90.0 & 13.0\end{array}$
TSH PRI FBS HBAIC RBS CAI TPR

$1.5011 .7132 .0 \quad 6.4 \quad 999.90 .6 \quad 8.4$

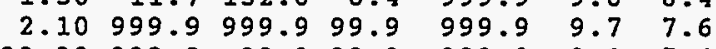

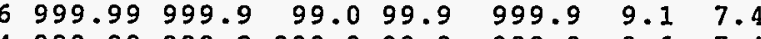
$\begin{array}{lllllll}999.99 & 999.9 & 999.9 & 99.9 & 999.9 & 9.6 & 7.4\end{array}$

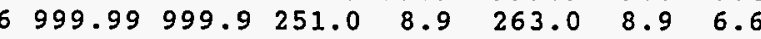

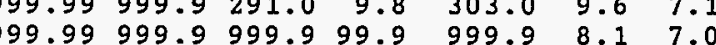

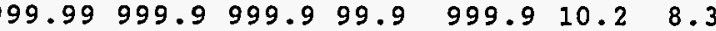

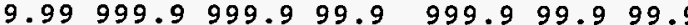
$4.70999 .9999 .999 .9 \quad 999.999 .47 .3$

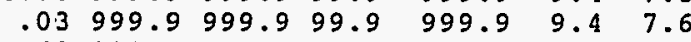

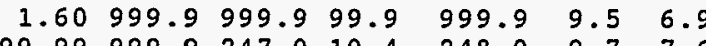
$248.0 \quad 9.7 \quad 7.6$ $999.9 \quad 9.2 \quad 7.0$ $\begin{array}{lll}999.9 & 9.5 & 7.4 \\ 999.9 & 9.0 & 7.7\end{array}$ 999.999 .999 .9 $999.9 \quad 9.2 \quad 7.8$ $\begin{array}{lll}194.0 & 9.7 & 6.7\end{array}$ $999.9 \quad 99.9 \quad 99.9$ $999.9 \quad 9.5 \quad 7.5$ $151.0 \quad 9.8 \quad 7.6$ $999.9 \quad 9.7 \quad 7.8$ $999.9 \quad 9.899 .9$ 248.0010 .309 .9 $248.0 \quad 10.3 \quad 8.2$ $999.9 \quad 9.7 \quad 8.9$ $\begin{array}{lll}228.0 & 9.5 & 7.6\end{array}$ $\begin{array}{lll}297.0 & 9.5 & 7.3\end{array}$ $271.0 \quad 9.5 \quad 7.8$ $301.0 \quad 9.1 \quad 7.4$ $999.9 \quad 10.0 \quad 7.5$ $999.9 \quad 9.6 \quad 7.4$ $\begin{array}{lllllll}1.90 & 10.4 & 999.9 & 99.9 & 999.9 & 9.0 & 7.2 \\ 3.20 & 17.0 & 331.0 & 12.7 & 376.0 & 8.8 & 6.4 \\ 1.90 & 28.1 & 999.9 & 99.9 & 999.9 & 8.8 & 7.1\end{array}$ $\begin{array}{lllllll}1.90 & 10.4 & 999.9 & 99.9 & 999.9 & 9.0 & 7.2 \\ 3.20 & 17.0 & 331.0 & 12.7 & 376.0 & 8.8 & 6.4 \\ 1.90 & 28.1 & 999.9 & 99.9 & 999.9 & 8.8 & 7.1\end{array}$

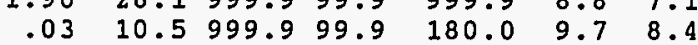

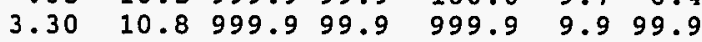
$\begin{array}{lllllll}1.90 & 8.9 & 999.9 & 99.9 & 158.0 & 9.2 & 7.1\end{array}$ $\begin{array}{lllllll}1.40 & 7.3 & 999.9 & 99.9 & 999.9 & 9.7 & 7.3\end{array}$

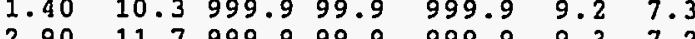

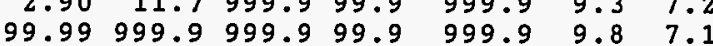
$\begin{array}{lrlllll}4.70 & 8.6 & 999.9 & 99.9 & 999.9 & 9.8 & 7.3\end{array}$ $\begin{array}{lllllll}1.30 & 5.6 & 999.9 & 99.9 & 999.9 & 99.9 & 6.7\end{array}$ $\begin{array}{lllllll}2.20 & 6.2 & 121.0 & 5.0 & 149.0 & 9.4 & 7.5\end{array}$

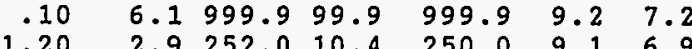
$4.60 \quad 2.9252 .0 \quad 10.4 \quad 250.0 \quad 9.1 \quad 6.9$ $3.10 \quad 6.1204 .0 \quad 6.6 \quad 192.0 \quad 9.8 \quad 7.7$ $1.00 \quad 6.6 \quad 222.0 \quad 8.8 \quad 221.0 \quad 10.0 \quad 7.6$ $\begin{array}{rrrrrrr}.90 & 7.2 & 84.0 & 5.7 & 999.9 & 9.2 & 6.7\end{array}$ $\begin{array}{rrrrrrr}1.20 & 3.1 & 103.0 & 99.9 & 999.9 & 9.4 & 7.4\end{array}$ 
COMPUTER LISTING OF 1989 RAW DATA 215 2160 2165

2171

2174

2176

2182

2188

2196

2197

2206

2207

2209

2210

-1
213

2217

2220

2224

2226

2227

2229

2231

2235

2236

2237

2239

2244

2245

2247
2248

2251

2254

2256

2257

2260

2261

2269

2271

2273

2274
WBC PMN BAND IXMPH MONO EOS BASO PLT HCT RBC

1770099999999999999999999999999999999999.99 .99999 .923 .8 $\begin{array}{rrrrrr}11700 & 99999 & 99999 & 99999 & 99999 & 99999 \\ 8400 & 3108 & 0 & 3360 & 420 & 1344 \\ 9500 & 3800 & 0 & 4655 & 950 & 190\end{array}$

$\begin{array}{rrrrrr}9500 & 3800 & 0 & 4655 & 950 & 190\end{array}$

$11000 \quad 5940$

$10100 \quad 4848$

101006060

$110 \quad 3410$

$0 \quad 4444$

770
808

660

$\begin{array}{llllll}0 & 350 & 45.4 & 4.88 & 91.0 & 15.2\end{array}$

$1003045.15 .20 \quad 87.014 .9$

\begin{tabular}{llllll}
0 & 240 & 47.6 & 4.82 & 90.0 & 14.6 \\
\hline & 52 & 90.0 & 16.0
\end{tabular}

6600
9400
59962

$5700 \quad 3135$

110006050

$5600 \quad 3360$

$5000 \quad 3450$

$14300 \quad 7007$
$6200 \quad 3968$

$7900 \quad 5451$

$8300 \quad 448$

$7700 \quad 4312$

$5900 \quad 3068$

$7700 \quad 554$

$10100 \quad 7272$

$8100 \quad 3564$

$9300 \quad 6510$

$7700 \quad 4543$

$6000 \quad 3900$

$\begin{array}{ll}5900 & 2714 \\ 7300 & 4745\end{array}$

7600

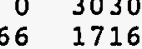

2726

$0 \quad 3630$

1121344

$50 \quad 1350$

$124 \quad 180$

1659
0

$77 \quad 2772$

02065

$0 \quad 1350$

$0 \quad 1386$

2121

2916
2325

$0 \quad 2002$

$360 \quad 1380$

$59 \quad 2301$

- 1825

$\begin{array}{ll}0 & 0 \\ 0 & 2280\end{array}$

$0 \quad 2240$

$69 \quad 2415$

$11200 \quad 7728$

$6900 \quad 3933$

$8000 \quad 4960$

$8000 \quad 4720$

03040

03168

$198 \quad 792$

79

188

$132400 \quad 46.8 \quad 4.94$

88.013 .8

$\begin{array}{lllll}475 & 48.8 & 5.64 & 87.0 & 16.3\end{array}$

$\begin{array}{llllll}0 & 360 & 52.3 & 5.71 & 92.0 & 17.0\end{array}$

$11233550.95 .68 \quad 90.016 .2$

$\begin{array}{llllll}0 & 380 & 36.5 & 3.93 & 93.0 & 11.9\end{array}$

$0 \quad 30539.6 \quad 5.00 \quad 79.013 .5$

$\begin{array}{lllllll}0 & 255 & 38.8 & 4.49 & 86.0 & 12.8\end{array}$

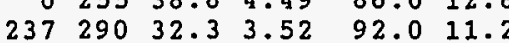

$\begin{array}{llllll}0 & 310 & 47.6 & 5.76 & 83.0 & 15.3\end{array}$

$\begin{array}{llllll}0 & 335 & 39.5 & 4.44 & 89.0 & 13.6\end{array}$

$\begin{array}{lllllll}0 & 235 & 46.6 & 5.57 & 84.0 & 15.2\end{array}$

$\begin{array}{llllll}75 & 355 & 39.9 & 4.54 & 88.0 & 13.2\end{array}$

$\begin{array}{lllllll}0 & 330 & 40.6 & 4.64 & 88.0 & 13.3\end{array}$

$\begin{array}{lllllll}0 & 350 & 37.6 & 4.59 & 82.0 & 12.4\end{array}$

$\begin{array}{lllllll}154 & 345 & 39.4 & 3.99 & 99.0 & 12.4\end{array}$

$\begin{array}{llllll}0 & 325 & 42.4 & 4.52 & 94.0 & 14.0\end{array}$

$\begin{array}{llllll}0 & 335 & 35.6 & 3.73 & 95.0 & 11.8\end{array}$

$\begin{array}{lllll}73 & 470 & 24.7 & 3.40 & 73.0\end{array}$

$\begin{array}{lllllll}0 & 270 & 39.4 & 5.11 & 77.0 & 13.3\end{array}$

$\begin{array}{llllll}0 & 410 & 39.0 & 4.65 & 84.0 & 12.2\end{array}$

$\begin{array}{llllll}112 & 255 & 40.8 & 4.58 & 89.0 & 13.4\end{array}$ $\begin{array}{llllll}0 & 435 & 42.1 & 4.80 & 88.0 & 13.9\end{array}$

$\quad 792 \quad 99$

$8800 \quad 6600 \quad 88 \quad 1584 \quad 264$

$7300 \quad 2628$

$6500 \quad 3315$

$6700 \quad 2814$

$\begin{array}{ll}88 & 1584 \\ 73 & 3796\end{array}$

$0 \quad 2470$

521508

521158

$0 \quad 2211$

$0 \quad 1240$

$\begin{array}{ll}1798 \\ 0 & 2652\end{array}$

01984

02067

$0 \quad 1296$

2479

2150
2573

o 3360

134

$\begin{array}{ll}1 & 34 \\ 1 & 35\end{array}$

50002200

$4300 \quad 4814$

$9400 \quad 5452$

$6500 \quad 3055$

$188 \quad 2726$

2726
0
2640

$\begin{array}{ll}511 & 219 \\ 455 & 260\end{array}$

$402 \quad 67$

$208 \quad 260$

$312 \quad 312$

372

496

312
248

106

216

300

672

$325 \quad 564$ $67 \quad 31042.7 \quad 4.65 \quad 92.0$ $034037.84 .32 \quad 88.011 .9$ $62320 \quad 37.8 \quad 4.32 \quad 88.011 .9$ $0230438.45 .06 \quad 86.014 .8$ $\begin{array}{rlllll}124 & 420 & 38.2 & 4.84 & 79.0 & 13.1\end{array}$

$\begin{array}{lllllll}0 & 310 & 43.6 & 5.31 & 82.0 & 14.2\end{array}$ $\begin{array}{lllllll}0 & 320 & 42.9 & 4.78 & 90.0 & 13.9\end{array}$ $\begin{array}{rrrrrr}150 & 310 & 49.6 & 5.40 & 92.0 & 16.3\end{array}$ $168290 \quad 48.5 \quad 5.57 \quad 87.016 .0$

$\begin{array}{lllll}188 & 394 & 52.8 & 6.19\end{array}$

$0 \quad 35547.5 \quad 5.19$

87.016.

TSH PRL FBS HBAIC RBS CAL TPR

$3.80999 .9999 .999 .9 \quad 999.999 .999 .9$ $\begin{array}{lllllll}07 & 5.3 & 260.0 & 6.0 & 267.0 & 9.3 & 7.6\end{array}$ $\begin{array}{lllllll}2.40 & 13.0 & 107.0 & 99.9 & 999.9 & 9.9 & 7.7\end{array}$ $\begin{array}{lllllll}3.80 & 6.3 & 999.9 & 99.9 & 999.9 & 9.6 & 7.4\end{array}$ $\begin{array}{lllllll}.90 & 9.9 & 183.0 & 9.6 & 273.0 & 9.6 & 7.3\end{array}$ $\begin{array}{lllllll}0.00 & 13.3 & 157.0 & 5.2 & 145.0 & 9.1 & 7.1\end{array}$ $\begin{array}{lllllll}1.70 & 12.7 & 278.0 & 9.1 & 287.0 & 9.1 & 7.0\end{array}$

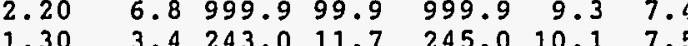

$\begin{array}{lllllll}3.90 & 27.8 & 999.9 & 99.9 & 999.9 & 10.3 & 8.1\end{array}$

$\begin{array}{lllllll}1.30 & 4.7 & 999.9 & 99.9 & 345.0 & 9.6 & 7.6\end{array}$

$2.80 \quad 7.8999 .999 .9 \quad 999.9 \quad 9.399 .9$

$\begin{array}{lllllll}.30 & 6.8 & 179.0 & 5.4 & 171.0 & 9.1 & 6.8\end{array}$

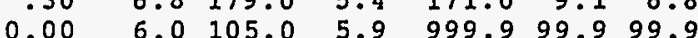

$\begin{array}{lllllll}4.20 & 26.1 & 999.9 & 99.9 & 999.9 & 9.6 & 6.6\end{array}$

$\begin{array}{lllllll}.80 & 8.8 & 258.0 & 11.6 & 256.0 & 10.1 & 7.6\end{array}$

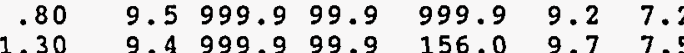

$\begin{array}{lllllll}.60 & 9.4 & 999.9 & 99.9 & 156.0 & 9.7 & 7.5\end{array}$

$\begin{array}{lllllll}1.90 & 9.0 & 999.9 & 99.9 & 999.9 & 9.7 & 7.4\end{array}$

$\begin{array}{lllllll}1.40 & 8.8 & 999.9 & 99.9 & 999.9 & 8.8 & 7.1\end{array}$

$\begin{array}{lllllll}.10 & 14.0 & 999.9 & 99.9 & 999.9 & 9.5 & 7.1\end{array}$

$\begin{array}{lllllll}.03 & 6.6 & 153.0 & 99.9 & 146.0 & 9.3 & 7.4\end{array}$

$\begin{array}{lllllll}2.10 & 9.4 & 999.9 & 99.9 & 999.9 & 9.8 & 8.3\end{array}$

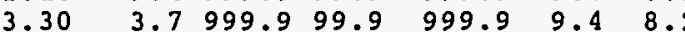

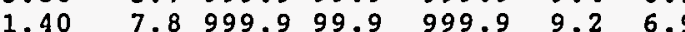

$4.60 \quad 17.9999 .999 .9 \quad 999.9 \quad 8.8 \quad 7.4$

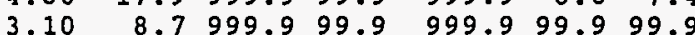

$1.80 \quad 13.2999 .999 .9$ 999.9 9.07 .3

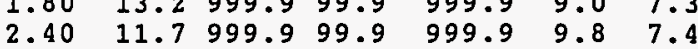

$\begin{array}{lllllll}.30 & 7.7 & 999.9 & 99.9 & 999.9 & 9.0 & 6.9\end{array}$

$\begin{array}{lllllll}1.30 & 8.7 & 247.0 & 15.0 & 254.0 & 10.5 & 7.4\end{array}$

$\begin{array}{lllllll}1.60 & 5.9 & 225.0 & 9.2 & 223.0 & 9.8 & 8.0\end{array}$

$\begin{array}{lllllll}3.30 & 4.9 & 999.9 & 99.9 & 999.9 & 9.3 & 7.8\end{array}$

$\begin{array}{lllllll}2.50 & 3.8 & 999.9 & 99.9 & 218.0 & 9.4 & 6.7\end{array}$

$\begin{array}{lllllll}2.10 & 8.9 & 89.0 & 99.9 & 149.0 & 9.4 & 8.3\end{array}$

$\begin{array}{lllllll}.60 & 8.1 & 999.9 & 99.9 & 999.9 & 8.7 & 7.0\end{array}$

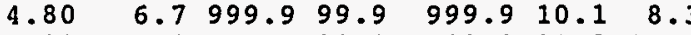

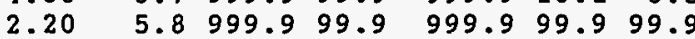

$.80 \quad 7.6 \quad 91.0 \quad 4.8 \quad 999.99 .000$

$2.20 \quad 6.4154 .06 .4099 .90 .808$

$2.10 \quad 8.4154 .0 \quad 6.4 \quad 99.90 .8 \quad 8.1$

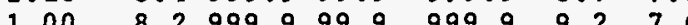
45.00

59.40

.80

1.00

2.90

.2 999.999 .9

3.7346 .013 .6

$4.7999 .9 \quad 99.9$

$6.5252 .0 \quad 7.0$

14.9999 .999 .9

$6.3 \quad 999.9$
1.60 4.9 4.3270 .013 .3 $\begin{array}{lll}999.9 & 9.2 \quad 7.6\end{array}$ $\begin{array}{llll}361.0 & 10.0 & 8.2\end{array}$ 9.9 99.9 .9.9 (10.3 7.9 247.09 .37 .1 $\begin{array}{lll}999.9 & 9.3 & 7.3\end{array}$ $999.9 \quad 9.8 \quad 8.0$ $999.9 \quad 10.0 \quad 8.4$ 275.010 .18 .4

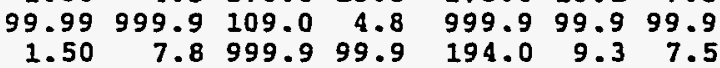




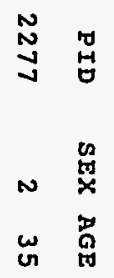

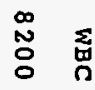

0
0
0

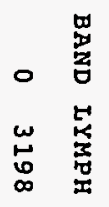

$\begin{array}{lll}n & 0 \\ \infty & 0\end{array}$

ज़

焉

$\begin{array}{lll}0 & 0 & 0\end{array}$

N

$\omega \quad \begin{aligned} & 0 \\ & \sim\end{aligned}$

on 5 架

叭

占思易

$\stackrel{n}{2} 2$

ம

$\begin{array}{ll}N & H \\ 0 & 0\end{array}$

is

$\begin{array}{ll}0 & 0 \\ 0 & 0 \\ 0 & 0\end{array}$

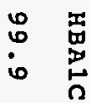

0
6
0

ڤै

10 
COMPUTER IISTING OF 1990 RAW DATA

$\begin{array}{rrr}\text { PID } & \text { SEX } & \text { AG } \\ 2 & 1 & 37 \\ 3 & 1 & 37 \\ 4 & 1 & 7 \\ 5 & 1 & 37 \\ 6 & 1 & 37 \\ 7 & 1 & 7 \\ 8 & 2 & 37 \\ 9 & 1 & 5 \\ 10 & 1 & 5 \\ 14 & 2 & 6 \\ 15 & 2 & 4 \\ 16 & 1 & 75 \\ 17 & 2 & 39 \\ 18 & 2 & 57 \\ 19 & 1 & 41 \\ 20 & 1 & 42 \\ 21 & 2 & 38 \\ 22 & 2 & 5 \\ 23 & 1 & 39 \\ 24 & 2 & 49 \\ 27 & 1 & 62 \\ 33 & 2 & 37 \\ 34 & 2 & 80 \\ 36 & 1 & 43 \\ 37 & 1 & 56 \\ 39 & 2 & 50 \\ 40 & 1 & 65 \\ 41 & 1 & 77 \\ 42 & 2 & 38 \\ 44 & 1 & 39 \\ 45 & 2 & 67 \\ 47 & 1 & 44 \\ 48 & 2 & 42 \\ 49 & 2 & 52 \\ 53 & 2 & 43 \\ 61 & 2 & 44 \\ 63 & 2 & 71 \\ 64 & 2 & 66 \\ 65 & 2 & 37 \\ 66 & 2 & 65 \\ 67 & 2 & 49 \\ 70 & 2 & 52 \\ 71 & 2 & 62 \\ 73 & 1 & 54 \\ 74 & 2 & 51 \\ 75 & 2 & 47 \\ 76 & 1 & 46 \\ 77 & 1 & 60 \\ 78 & 2 & 71 \\ 79 & 1 & 75 \\ 81 & 2 & 44 \\ 86 & 2 & 35 \\ 805 & 2 & 36 \\ 811 & 2 & 36 \\ & & \end{array}$

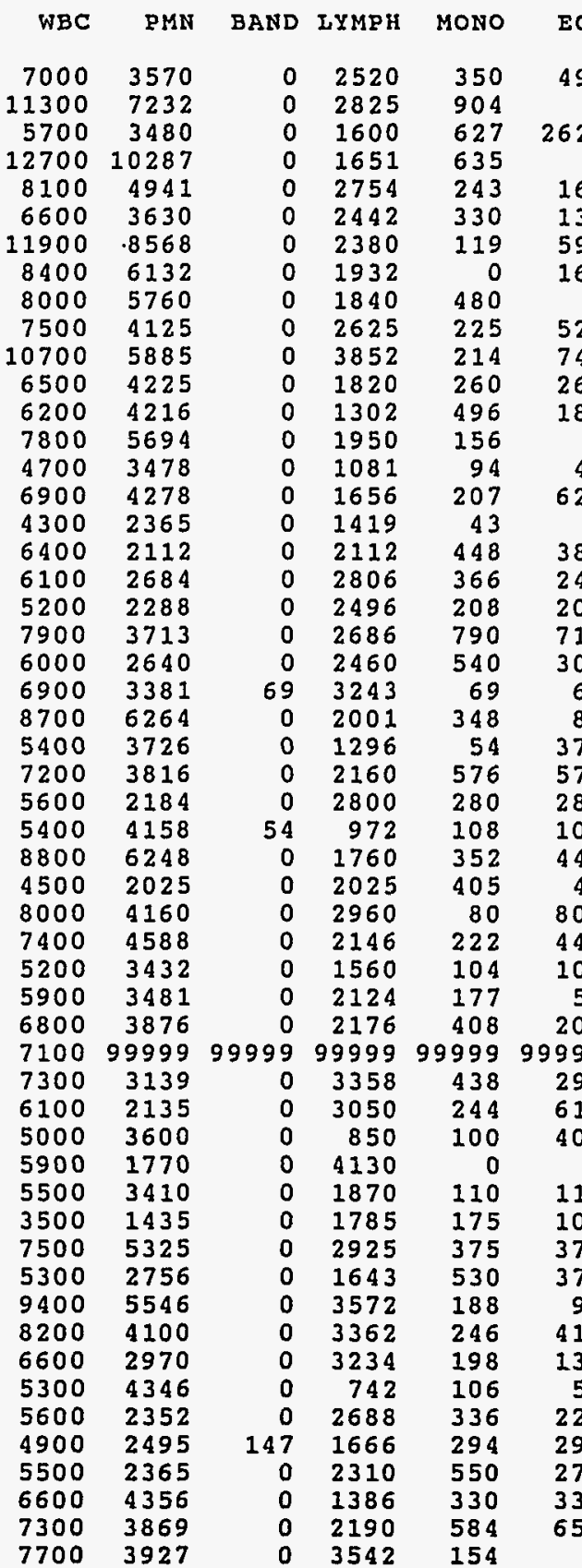

EOS BASO PLT HCT RBC

MCV HGB

TSH

PRL FBS HBAIC

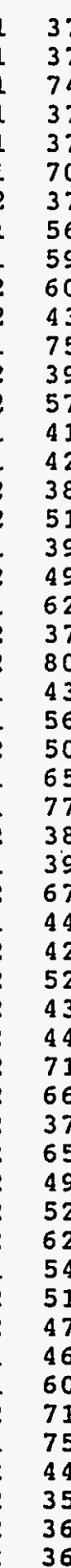

490

$\begin{array}{lllll}70 & 213 & 42.3 & 4.52\end{array}$

$94.0 \quad 14.8$

20999.9999 .999 .9 $342 \quad 20739.6 \quad 4.72$

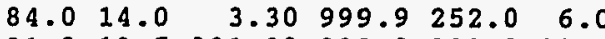
127.26538 .04 .18 $91.0 \quad 13.5 \quad 391.00 \quad 999.9999 .9 \quad 99.9$

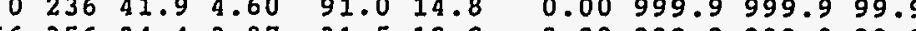

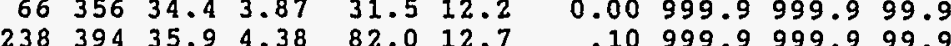
$\begin{array}{lllllll}238 & 394 & 35.9 & 4.38 & 82.0 & 12.7\end{array}$ $\begin{array}{llllll}168 & 206 & 38.2 & 4.21 & 91.0 & 13.4\end{array}$ $\begin{array}{llllll}0 & 304 & 43.1 & 5.24 & 82.0 & 14.5 \\ 0 & 253 & 33.8 & 3.61 & 94.0 & 12.3\end{array}$ $\begin{array}{llllll}0 & 328 & 37.8 & 4.11 & 92.0 & 13.0\end{array}$ $\begin{array}{lllllll}0 & 283 & 38.0 & 5.18 & 73.0 & 12.6\end{array}$ $\begin{array}{llllll}0 & 278 & 34.8 & 4.57 & 76.0 & 11.8\end{array}$ $\begin{array}{lllllll}0 & 291 & 33.5 & 3.86 & 87.0 & 12.8\end{array}$ $0013.53 .86 \quad 87.011 .8$ $\begin{array}{llllll}138 & 297 & 47.1 & 5.66 & 83.0 & 16.2\end{array}$ $\begin{array}{llllll}43 & 251 & 35.3 & 4.55 & 78.0 & 11.8\end{array}$

$\begin{array}{llllll}0 & 253 & 38.6 & 4.27 & 90.0 & 13.4\end{array}$

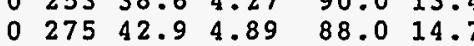
$\begin{array}{llllll}0 & 236 & 41.2 & 4.78 & 86.2 & 14.8\end{array}$ $\begin{array}{lllllll}79 & 198 & 40.8 & 4.17 & 98.0 & 15.0\end{array}$ $\begin{array}{rrrrrr}60 & 309 & 37.8 & 4.59 & 82.0 & 13.1 \\ 69 & 184 & 34.3 & 3.44 & 100.0 & 11.8\end{array}$ $\begin{array}{lllllll}0 & 272 & 32.4 & 3.39 & 96.0 & 11.6\end{array}$ $\begin{array}{llllll}0 & 164 & 37.5 & 3.96 & 95.0 & 13.6\end{array}$ $\begin{array}{llllll}72 & 414 & 38.4 & 4.26 & 90.0 & 12.7\end{array}$ $\begin{array}{llllll}56 & 279 & 36.3 & 4.11 & 88.0 & 12.6\end{array}$ $\begin{array}{lllllll}0 & 158 & 32.5 & 3.78 & 86.0 & 11.6\end{array}$ $\begin{array}{lllllll}0 & 252 & 35.6 & 3.72 & 96.0 & 13.2\end{array}$ $\begin{array}{lllllll}0 & 237 & 44.6 & 5.41 & 83.0 & 15 .\end{array}$ $\begin{array}{lrrrrr}0 & 321 & 34.8 & 3.75 & 93.0 & 12.7 \\ 0 & 264 & 41.0 & 4.10 & 100.0 & 15.1\end{array}$ $\begin{array}{rrrrrr}0 & 264 & 41.0 & 4.10 & 100.0 & 15.1 \\ 0 & 278 & 38.9 & 4.04 & 96.3 & 12.9\end{array}$ $\begin{array}{rrrrrr}0 & 278 & 38.9 & 4.04 & 96.3 & 12.9\end{array}$ $\begin{array}{rrrrrr}59 & 251 & 39.5 & 4.59 & 86.0 & 14.2 \\ 136 & 382 & 37.7 & 4.18 & 90.0 & 13.5\end{array}$ $\begin{array}{rrrrrr}136 & 382 & 37.7 & 4.18 & 90.0 & 13.5 \\ 9999 & 304 & 43.8 & 4.83 & 90.7 & 14.6\end{array}$ $\begin{array}{llllll}73 & 218 & 40.9 & 4.57 & 89.0 & 14.1\end{array}$ $\begin{array}{lllllll}61 & 220 & 38.3 & 4.19 & 91.0 & 13.3\end{array}$ $\begin{array}{llllll}50 & 244 & 32.6 & 3.67 & 89.0 & 11.2\end{array}$ $\begin{array}{lllllll}0 & 225 & 36.7 & 4.17 & 88.0 & 12.7\end{array}$ $\begin{array}{llllll}0 & 280 & 36.2 & 3.86 & 94.0 & 12.6\end{array}$ $\begin{array}{llllll}0 & 268 & 42.1 & 4.63 & 91.0 & 14.8\end{array}$ $\begin{array}{llllll}0 & 186 & 45.3 & 4.72 & 96.0 & 15.9\end{array}$ $\begin{array}{llllll}0 & 277 & 44.6 & 5.03 & 89.0 & 15.9\end{array}$ $\begin{array}{llllll}82 & 246 & 38.6 & 4.35 & 89.0 & 13.1\end{array}$ $132 \quad 188 \quad 45.14 .86 \quad 93.016 .0$

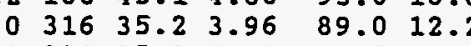
$\begin{array}{llllll}0 & 231 & 37.8 & 4.11 & 92.0 & 13.4\end{array}$ $\begin{array}{llllll}0 & 131 & 45.2 & 4.98 & 90.8 & 15.2\end{array}$ $\begin{array}{rrrrrrr}0 & 274 & 40.6 & 4.61 & 88.0 & 14.3 \\ 198 & 229 & 34.2 & 4.13 & 83.0 & 13.0\end{array}$ .10999 .9999 .999 .9 $2.30 \quad 999.9 \quad 95.0 \quad 5.1$ $\begin{array}{llll}1.80 & 999.9 & 347.0 & 12.2\end{array}$ $.10 \quad 999.9 \quad 107.0 \quad 99.9$ $6.10999 .9 \quad 999.999 .9$ $5.20 \quad 999.9 \quad 999.9 \quad 99.9$ $0.00 \quad 999.9 \quad 999.9 \quad 99.9$ $0.00 \quad 22.2 \quad 999.9$ $\begin{array}{llll}1.60 & 2.7 & 101.0 & 5.0\end{array}$ 26.70999 .9999 .999 .9 $2.80 \quad 31.0 \quad 999.9 \quad 99.9$ $8.10 \quad 16.1 \quad 999.9 \quad 99.9$ $\begin{array}{rlll}.20 & 4.1 & 100.0 & 4.8\end{array}$ $\begin{array}{llll}1.20 & 2.7 & 137.0 & 4.5\end{array}$ $\begin{array}{lllll}9.30 & 4.5 & 106.0 & 2.4\end{array}$ $\begin{array}{llll}6.80 & 12.3 & 999.9 & 99.9\end{array}$ $\begin{array}{llll}85.50 & 5.5 & 999.9 & 99.9\end{array}$ $.80 \quad 3.3 \quad 999.999 .9$ $\begin{array}{llll}2.90 & 8.1 & 999.9 & 99.9\end{array}$ $\begin{array}{rrrr}1.40 & 0.0 & 84.0 & 5.4 \\ 6.90 & 5.3 & 999.9 & 99.9\end{array}$ $0.00 \quad 3.799 .999 .9$ $2.00 \quad 3.799 .999 .9$ $.40 \quad 8.6 \quad 999.9$
290.9 $2.90 \quad 3.5999 .999 .9$ $2.90 \quad 999.9 \quad 999.9 \quad 99.9$ $\begin{array}{llll}1.30 & 4.3 & 286.0 & 8.7\end{array}$ $\begin{array}{llll}7.50 & 6.7 & 999.9 & 99.9\end{array}$ $38.90 \quad 999.9 \quad 313.0 \quad 99.9$ $\begin{array}{lllll}2.10 & 8.8 & 999.9 & 99.9\end{array}$ $\begin{array}{llll}0.00 & 4.5 & 999.9 & 99.9\end{array}$ $\begin{array}{llll}69.50 & 29.6 & 999.9 & 99.9\end{array}$ $\begin{array}{llll}.70 & 2.9 & 96.0 & 99.9\end{array}$ $4.10 \quad 7.3 \quad 999.999 .9$ $52.90 \quad 5.0 \quad 999.9 \quad 99.9$ $\begin{array}{llll}2.90 & 3.7 & 999.9 & 99.9\end{array}$ $.60 \quad 4.4 \quad 999.999 .9$ $\begin{array}{llll}2.20 & 9.7 & 89.0 & 4.6\end{array}$ $\begin{array}{lllll}9.60 & 4.9 & 165.0 & 7.7\end{array}$ $\begin{array}{lllll}2.80 & 10.8 & 999.9 & 99.9\end{array}$

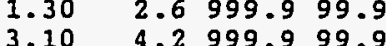
$\begin{array}{rrrr}3.10 & 4.2 & 999.9 & 99.9 \\ 2.30 & 999.9 & 139.0 & 7.2\end{array}$ $0.00 \quad 4.1999 .999 .9$

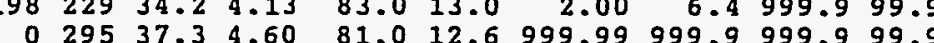

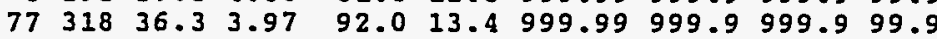


COMPUTER IISTING OF 1990 RAW DATA 
PID 1519

1524

1542

1546

1548

1549

1553

1558

1559

1563

1564

1572

157

2102

2103

2104

2105

2106

2107

2108

2110

2111

2113

2114

2117

124

1126

2126

130

2130

2134

2136

2138

2139

2142

2144

2145

2148

2149

2150

15

2153

1155

2156

2158

2160

2166

2167

2171

2172

2174
WB

6200
6588

6100
7300 3538

$\begin{array}{ll}7300 & 2701 \\ 5700 & 2508\end{array}$

$10600 \quad 7420$

$3200 \quad 960$

$8800 \quad 4928$

$6300 \quad 3402$

$6000 \quad 2940$

$6300 \quad 3402$

$7800 \quad 4836$

$4100 \quad 1517$

$5900 \quad 1947$

$7600 \quad 5472$

96006816

$9600 \quad 6816$

$6500 \quad 3705$

$4800 \quad 2544$

$9900 \quad 5841$

$11300 \quad 7119$

$17200 \quad 11696$

$5400 \quad 2808$

104007280

6500
7500 3359999

$7600 \quad 5320$

$6500 \quad 3315$

$6600 \quad 2838$

$6800 \quad 3876$

$7000 \quad 3920$

67003886

$6700 \quad 3886$

$3800 \quad 2014$

38002014

59003127

$5500 \quad 2805$

$7000 \quad 4690$

$5900 \quad 2950$

60003180

$5200 \quad 270$

$4900 \quad 2646$

$6100 \quad 2867$

$7300 \quad 2920$

$8400 \quad 5292$

$5400 \quad 3024$

51003060

$7900 \quad 4503$

$7900 \quad 4503$

4902156

4200218

$5100 \quad 2448$

59003009

$6200 \quad 3286$

$8800 \quad 5456$

$6400 \quad 3456$

$8500 \quad 5695$

\section{COMPUTER IISTING OF 1990 RAW DATA}

BAND LYMPH MONO EOS BASO PLT HCT RBC MCV HGB TSH PRI FBS HBAIC

$\begin{array}{rrrr}0 & 1364 & 248 & 0 \\ 0 & 2379 & 122 & 61 \\ 0 & 4088 & 365 & 146 \\ 0 & 2850 & 342 & 57 \\ 0 & 3074 & 106 & 0 \\ 0 & 1856 & 320 & 64 \\ 0 & 3168 & 440 & 264 \\ 0 & 2142 & 441 & 315 \\ 0 & 2880 & 120 & 60 \\ 0 & 2142 & 189 & 504 \\ 0 & 2808 & 156 & 0 \\ 0 & 2501 & 82 & 0 \\ 0 & 3363 & 177 & 413 \\ 0 & 1368 & 608 & 76 \\ 0 & 2016 & 384 & 384 \\ 0 & 2196 & 366 & 0 \\ 65 & 1365 & 124 & 130 \\ 0 & 1728 & 192 & 336 \\ 0 & 2475 & 495 & 990 \\ 0 & 3503 & 113 & 452 \\ 0 & 4988 & 172 & 344 \\ 0 & 1998 & 270 & 216 \\ 0 & 2392 & 728 & 0 \\ 99 & 1625 & 455 & 390 \\ 0 & 2250 & 600 & 375 \\ 0 & 1140 & 760 & 304 \\ 0 & 2730 & 260 & 195 \\ 0 & 3102 & 198 & 462 \\ 0 & 1700 & 612 & 544 \\ 0 & 2520 & 210 & 420 \\ 0 & 2412 & 201 & 134 \\ 0 & 1794 & 78 & 156 \\ 0 & 1558 & 114 & 114 \\ 0 & 2301 & 354 & 118 \\ 0 & 2145 & 385 & 165 \\ 0 & 1820 & 210 & 350 \\ 0 & 2065 & 708 & 177 \\ 0 & 1980 & 600 & 120 \\ 0 & 1924 & 416 & 156 \\ 0 & 2617 & 147 & 147 \\ 0 & 2257 & 610 & 244 \\ 0 & 3139 & 365 & 657 \\ 0 & 2184 & 588 & 336 \\ 0 & 1836 & 108 & 432 \\ 0 & 1632 & 153 & 255 \\ 0 & 2607 & 553 & 237 \\ 0 & 1960 & 392 & 294 \\ 0 & 1638 & 294 & 42 \\ 0 & 2091 & 153 & 357 \\ 0 & 2124 & 354 & 413 \\ 0 & 2728 & 186 & 0 \\ 0 & 2552 & 704 & 0 \\ 0 & 2304 & 448 & 192 \\ 0 & 1785 & 425 & 510 \\ & & & \end{array}$

$\begin{array}{llll}0 & 259 & 45.9 & 5.18\end{array}$ $\begin{array}{lllll}0 & 215 & 45.5 & 5.00\end{array}$

$\begin{array}{lllll}0 & 243 & 37.9 & 4.34\end{array}$

$\begin{array}{lllll}0 & 240 & 43.0 & 5.44 \\ 0 & 132 & 45.5 & 4.99\end{array}$

$0 \begin{array}{lllll}0 & 257 & 34.4 & 3.82\end{array}$

$\begin{array}{lllll}0 & 271 & 41.6 \quad 4.78\end{array}$

$\begin{array}{lllll}0 & 294 & 37.1 & 4.07 \\ 63 & 287 & 38.0 & 9.25\end{array}$

$63 \quad 28738.0 \quad 4.25$

$\begin{array}{lllll}0 & 338 & 42.7 & 5.38\end{array}$

$\begin{array}{rrrr}41 & 249 & 42.6 & 4.76 \\ 0 & 282 & 37.0 & 4.29\end{array}$

$\begin{array}{lllll}76 & 198 & 48.8 & 5.77\end{array}$

$\begin{array}{llll}0 & 318 & 37.3 & 4.22\end{array}$

$61300044.7 \quad 4.87$

0
0 2537.14 .09

$\begin{array}{llll}99 & 416 & 35.7 & 4.08\end{array}$

$\begin{array}{rrrr}113 & 268 & 43.3 & 5.13 \\ 0 & 215 & 35.4 & 4.14\end{array}$

$\begin{array}{rlll}0 & 215 & 35.4 & 4.14 \\ 08 & 242 & 39.5 & 4.50\end{array}$

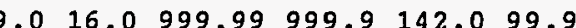
$\begin{array}{llllll}0.0 & 14.4 & 999.99 & 999.9 & 265.0 & 8.2\end{array}$ $91.016 .4 \quad 999.9999 .9$ 999.9 99.9 $79.0 \quad 15.4 \quad 999.99 \quad 999.9 \quad 252.0 \quad 7.6$ $\begin{array}{llllll}91.0 & 16.2 & 999.99 & 999.9 & 351.0 & 7.0\end{array}$

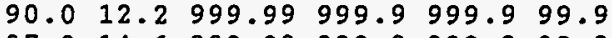

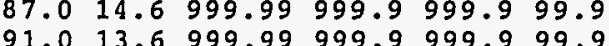
89.013 .6 1.

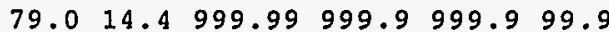
$90.015 .3 \quad 999.99 \quad 999.9 \quad 999.9 \quad 99.9$ $\begin{array}{llllll}86.0 & 13.2 & 1.00 & 999.9 & 91.0 & 9.5\end{array}$ $\begin{array}{llllll}85.0 & 17.0 & 999.99 & 999.9 & 999.9 & 99.9\end{array}$

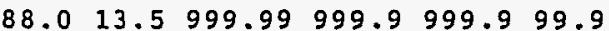
$92.0 \quad 16.3 \quad 999.99 \quad 999.9999 .999 .9$

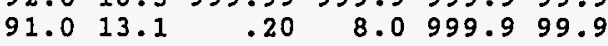
$\begin{array}{llllll}91.0 & 13.1 & 6.20 & 8.6 & 150.0 & 4.6\end{array}$ $\begin{array}{llllll}87.0 & 12.7 & 2.00 & 10.9 & 999.9 & 99.9\end{array}$

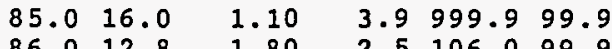
$\begin{array}{llllll}0.52 & 39.5 & 4.50 & 88.0 & 12.8\end{array}$ $\begin{array}{llll}3.8 & 3.38 & 100.0 & 12.3\end{array}$ $\begin{array}{llll} & \end{array}$ $\begin{array}{llllll}0 & 325 & 40.4 & 5.15 & 79.0 & 14.0\end{array}$ $\begin{array}{lllllll}0 & 222 & 39.4 & 4.63 & 85.0 & 14.0\end{array}$ $\begin{array}{lllllll}0 & 249 & 42.6 & 4.68 & 91.0 & 15.3\end{array}$ $\begin{array}{lllll}68 & 225 & 42.3 & 4.86\end{array}$ $\begin{array}{llll}0 & 349 & 37.4 & 4.36\end{array}$ $\begin{array}{llll}6 & 390 & 33.9 & 4.49\end{array}$

$\begin{array}{lllll}0 & 211 & 34.7 & 4.11 \\ 0 & 240 & 37.9 & 4.77\end{array}$

$\begin{array}{lllll}0 & 234 & 40.8 & 4.67\end{array}$

$\begin{array}{llll}0 & 270 & 41.4 & 4.52 \\ 0 & 376 & 35.4 & 4.21\end{array}$

$\begin{array}{lllll}0 & 376 & 35.4 & 4.21 \\ 0 & 326 & 35.7 & 3.87\end{array}$

$\begin{array}{lllll}120 & 179 & 42.3 & 4.64\end{array}$

$\begin{array}{lllll}0 & 257 & 48.1 & 5.01 \\ 0 & 296 & 40.9 & 4.33\end{array}$

$\begin{array}{llll}0296 & 40.9 & 4.33\end{array}$

$\begin{array}{lllll}219 & 297 & 33.1 & 3.76\end{array}$

$\begin{array}{lllll}0 & 207 & 47.7 & 5.75\end{array}$

$\begin{array}{llll}0 & 298 & 42.6 & 4.74 \\ 0 & 257 & 41.0 & 5.24\end{array}$

$\begin{array}{llll}0 & 273 & 51.4 & 5.96\end{array}$

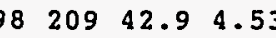

$\begin{array}{llll}42 & 267 & 37.1 & 4.30 \\ 51 & 292 & 43.8 & 4.89\end{array}$

$\begin{array}{llll}1 & 292 & 43.8 & 4.89 \\ 0 & 224 & 39.3 & 4.52\end{array}$

$\begin{array}{lllll}0 & 224 & 39.3 & 4.52 \\ 0 & 225 & 44.1 & 5.10\end{array}$

$\begin{array}{llll}0 & 282 & 38.0 & 4.51\end{array}$

$\begin{array}{rrrr}0 & 280 & 39.8 & 4.92\end{array}$

$\begin{array}{llll}85 & 326 & 46.6 \quad 5.32\end{array}$

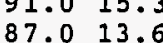

87.014 .5

85.012 .7 76.012 .1 85.012 .1 80.013 .3 92.014 .3 84.012 .2 92.012 .2 1.015 .3 96.017 .6 $91.0 \quad 13.5$ 88.011 .9 $83.0 \quad 16.6$ 90.015 .6 86.018 .1 95.015 .6 86.013 .1

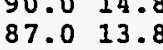
87.015 .7 84.013 .4 88.016 .5

3.80

$\begin{array}{llll}3.30 & 11.7 & 95.0 & 3.7\end{array}$

$\begin{array}{llll}3.00 & 2.5 & 999.9 & 99.9\end{array}$

$\begin{array}{llll}1.50 & 6.0 & 279.0 & 8.4\end{array}$

$\begin{array}{llll}2.20 & 5.7 & 318.0 & 8.7\end{array}$

$\begin{array}{llll}1.40 & 9.7 & 294.0 & 5.2 \\ 1.80 & 3.7 & 293.0 & 7.2\end{array}$

$.903 .3 \quad 999.999 .9$

$2.20 \quad 46.4999 .909 .9$

9011.4999 .999 .9

3.6011 .2394 .9

$1.30 \quad 32.9 \quad 999.9 \quad 99.9$

$0.00 \quad 7.5 \quad 94.0 \quad 8.4$ $2.60 \quad 10.8 \quad 999.9 \quad 99.9$ $\begin{array}{llll}1.70 & 7.2 & 98.0 & 6.6\end{array}$ $\begin{array}{llll}1.20 & 7.9 & 999.9 & 99.9\end{array}$ $4.20 \quad 12.7 \quad 999.9 \quad 99.9$

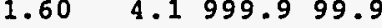
$2.10 \quad 5.0 \quad 999.9 \quad 99.9$ $\begin{array}{llll}2.50 & 7.6 & 116.0 & 6.9\end{array}$ $\begin{array}{llll}4.20 & 4.2 & 999.9 & 99.9 \\ 1.40 & 3.5 & 999.9 & 99.9\end{array}$ $1.10 \quad 2.6 \quad 296.0 \quad 9.8$ 1.1099 .6909

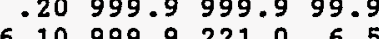
$6.10 \quad 999.9221 .0 \quad 6.5$ 1.00999 .9999 .999 .9 1.00999 .9999 .999 .9 $.20999 .9301 .0 \quad 9.2$

$4.20 \quad 999.9 \quad 999.9 \quad 99.9$

$\begin{array}{llll}.70 & 999.9 & 158.0 & 5.7\end{array}$ $\begin{array}{llll}.20 & 999.9 & 93.0 & 4.3\end{array}$ $\begin{array}{llll}2.20 & 999.9 & 234.0 & 10.9\end{array}$ 
COMPUTER LISTING OF 1990 RAW DATA

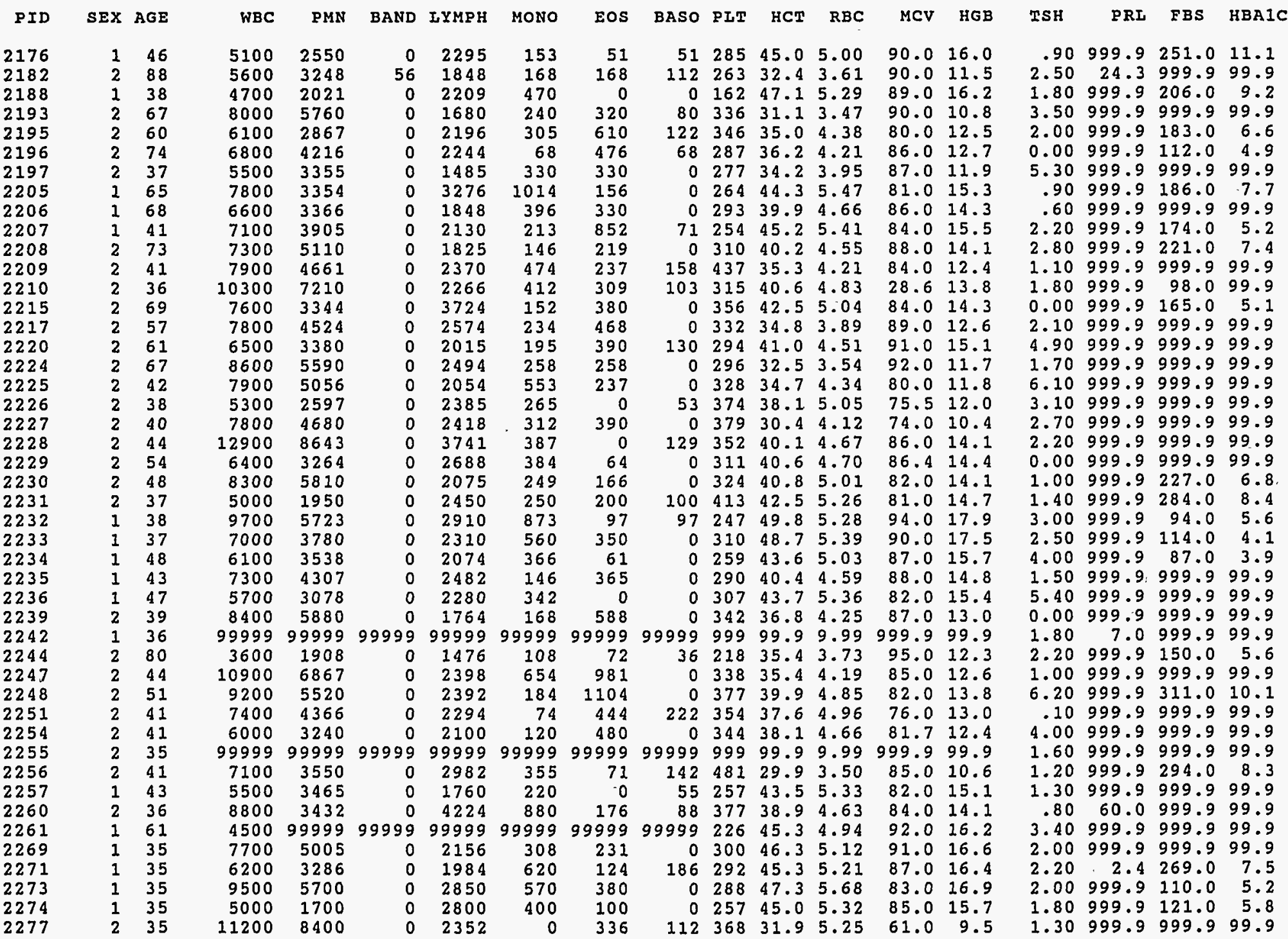


COMPUTER IISTING OF 1991 RAW DATA

241.09 .7 $3.00 \quad 0.0999 .999 .9$ 2.30999 .9999 .999 .9 $5.80999 .9 \quad 999.999 .9$ 
COMPUTER IISTING OF 1991 RAW DATA

$\begin{array}{llll}108 & 270 & 44.8 & 5.07\end{array}$ $\begin{array}{lllll}41 & 213 & 42.9 & 4.82\end{array}$ $\begin{array}{llll}53 & 347 & 38.2 & 4.48\end{array}$ $\begin{array}{lllll}49 & 220 & 33.8 & 3.88\end{array}$ 40739.44 .58
156 $\begin{array}{llll}156 & 273 & 39.6 & 4.04 \\ 112 & 257 & 46.1 & 5.03\end{array}$

$\begin{array}{rlll}0 & 232 & 40.0 & 4.97\end{array}$ $\begin{array}{lllll}74 & 265 & 42.9 & 5.18\end{array}$ $\begin{array}{lllll}106 & 252 & 44.5 & 5.15\end{array}$ $\begin{array}{rrrr}0 & 281 & 42.1 & 4.61 \\ 84 & 252 & 51.9 & 5.63\end{array}$

$\begin{array}{llll}0 & 350 & 47.0 & 5.93\end{array}$

$\begin{array}{llll}48 & 228 & 36.2 & 4.10\end{array}$

$\begin{array}{llll}0 & 261 & 41.4 & 4.44\end{array}$ $\begin{array}{lllll}120 & 238 & 39.9 & 4.67\end{array}$

$\begin{array}{llll}0 & 179 & 33.9 & 3.70\end{array}$

$\begin{array}{rrrr}0 & 999 & 38.8 & 4.29\end{array}$

$\begin{array}{llll}90 & 292 & 39.6 & 4.39 \\ 52 & 179 & 45.0 & 5.26\end{array}$ $9999424 \quad 41.8 \quad 5.00$ $\begin{array}{llll}150 & 239 & 39.6 & 4.00\end{array}$

$\begin{array}{lllll}60 & 259 & 36.7 & 4.14\end{array}$

$\begin{array}{lllll}0 & 270 & 41.1 & 4.70\end{array}$

$\begin{array}{rrrr}47 & 321 & 37.3 & 4.20 \\ 0 & 271 & 33.7 & 3.96\end{array}$

$\begin{array}{llll}170 & 199 & 40.4 & 4.39\end{array}$

$\begin{array}{llll}0 & 264 & 32.8 & 3.65\end{array}$

$204 \quad 186 \quad 38.6 \quad 4.43$

$\begin{array}{lllll}122 & 261 & 44.3 & 5.17\end{array}$

$\begin{array}{rlll}54 & 2510 & 34.7 & 3.75 \\ 0 & 358 & 38.3 & 5.58\end{array}$

$\begin{array}{llll}0 & 358 & 38.5 & 4.33\end{array}$

$\begin{array}{lllll}0 & 288 & 40.0 & 4.63\end{array}$

$\begin{array}{lllll}300 & 308 & 36.9 & 4.31\end{array}$

$\begin{array}{llll}83 & 239 & 41.9 & 4.76 \\ 0 & 387 & 38.4 & 4.47\end{array}$ $\begin{array}{lllll}0 & 310 & 43.4 & 5.00\end{array}$ $\begin{array}{llll}106 & 323 & 35.6 & 4.15\end{array}$ $\begin{array}{lllll}0 & 242 & 40.7 & 4.68\end{array}$ $144 \quad 198 \quad 43.4 \quad 4.79$ $\begin{array}{llll}56 & 225 & 40.8 & 4.71\end{array}$ $71238 \quad 38.4 \quad 4.83$

$\begin{array}{llll}71 & 238 & 38.4 & 4.83 \\ 0 & 198 & 34.9 & 3.98\end{array}$

$0316 \quad 40.74 .84$ $\begin{array}{llll}0 & 281 & 48.5 & 5.40\end{array}$ $\begin{array}{lllll}51 & 267 & 40.0 & 4.97\end{array}$ $\begin{array}{rlll}81 & 231 & 47.0 & 5.15 \\ 0 & 336 & 37.0 & 4.17\end{array}$

$\begin{array}{llll}0 & 266 & 37.5 & 4.30\end{array}$

$\begin{array}{llll}0 & 113 & 47.9 & 5.25\end{array}$

$9029132.7 \quad 3.61$

MCV HGB TSH PRL FBS HBAIC

$\begin{array}{llllll}88.3 & 14.9 & .70 & 999.9 & 999.9 & 99.9\end{array}$ $\begin{array}{llllll}89.1 & 14.9 & 999.99 & 999.9 & 999.9 & 99.9\end{array}$ $\begin{array}{llllll}85.3 & 12.9 & 999.99 & 999.9 & 999.9 & 99.9\end{array}$ $\begin{array}{llllll}87.0 & 11.3 & 4.50 & 999.9 & 999.9 & 99.9\end{array}$ $\begin{array}{llllll}86.0 & 12.4 & 999.99 & 999.9 & 100.0 & 5.1\end{array}$

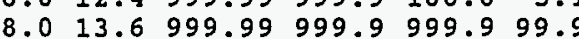

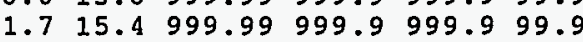
$\begin{array}{llllll}80.5 & 13.2 & 999.99 & 999.9 & 172.0 & 7.9\end{array}$ $\begin{array}{llllll}82.8 & 14.8 & 1.30 & 999.9 & 999.9 & 99.9\end{array}$

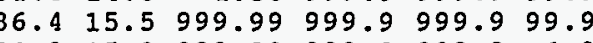
$\begin{array}{lllllll}91.3 & 15.0 & 999.99 & 999.9 & 203.0 & 6.3\end{array}$ $\begin{array}{llllll}2.2 & 17.4 & 999.99 & 999.9 & 999.9 & 99.9\end{array}$ $\begin{array}{llllll}79.3 & 15.8 & 2.00 & 4.1 & 999.9 & 99.9\end{array}$

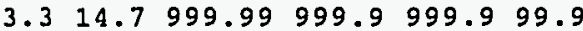

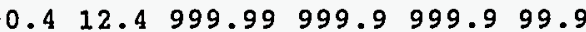
85.413 .2999 .99999 .9999 .999 .9

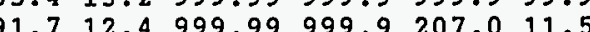
90.013 .4299 .990011 .5 0.313 .2 9 14.1909 85.615 .3 .50 159.9

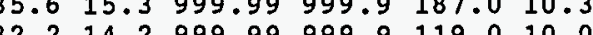

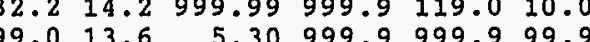
$\begin{array}{llllll}8 & 13.6 & 5.30 & 999.9 & 999.9 & 99.9\end{array}$ $\begin{array}{llllll}88.7 & 12.6 & 1.00 & 999.9 & 999.9 & 4.4\end{array}$ $\begin{array}{lllllll}87.4 & 14.3 & 999.99 & 999.9 & 126.0 & 6.7\end{array}$ $\begin{array}{llllll}88.7 & 12.8 & 999.99 & 14.1 & 999.9 & 99.9\end{array}$ $\begin{array}{llllll}5.0 & 11.8 & 999.99 & 999.9 & 999.9 & 99.9\end{array}$ $\begin{array}{lllllll}2.0 & 14.0 & 999.99 & 999.9 & 145.0 & 7.0\end{array}$ $\begin{array}{llllll}89.9 & 11.3 & 999.99 & 999.9 & 999.9 & 99.9\end{array}$ $\begin{array}{llllll}8 & 113.2 & 1.90 & 999.9 & 999.9 & 99.9\end{array}$ 85.715 .1999 .99999 .9151 .07 .8 $92.4 \quad 1.1 .8 \quad 39.70999 .9 \quad 165.0 \quad 6.9$ $84.816 .8 \quad 39.70$ 29.9 165.06 .9 89.816 .20 .00999 .9156 .07 .9

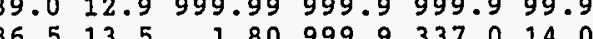
$\begin{array}{llllll}85.5 & 13.5 & 1.80 & 999.9 & 337.0 & 14.0\end{array}$ $88.114 .5 \quad 999.99 \quad 7.399 .999 .9$ $\begin{array}{llllll}86.1 & 14.0 & 2.20 & 4.9 & 999.9 & 99.9\end{array}$ $\begin{array}{llllll}86.0 & 12.6 & 2.10 & 999.9 & 999.9 & 99.9\end{array}$ $\begin{array}{llllll}86.8 & 14.9 & 999.99 & 999.9 & 999.9 & 99.9\end{array}$ $\begin{array}{llllll}85.7 & 12.3 & 999.99 & 11.6 & 206.0 & 8.4\end{array}$ $\begin{array}{llllll}86.9 & 13.4 & 1.30 & 13.9 & 999.9 & 99.9\end{array}$

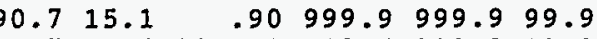
$\begin{array}{llllll}86.7 & 13.6 & 999.99 & 10.5 & 999.9 & 99.9\end{array}$ $\begin{array}{llllll}85.4 & 14.1 & 999.99 & 999.9 & 263.0 & 9.2\end{array}$ $79.6 \quad 13.1 \quad 999.99999 .9999 .999 .9$ $87.612 .0 \quad 9.40 \quad 9.3193 .0910 .0$

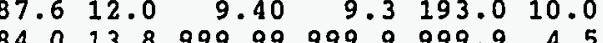
$\begin{array}{llllll}89.0 & 13.8 & 999.99 & 999.9 & 999.9 & 4.5\end{array}$

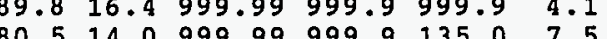
$81.314 .0999 .99999 .9135 .0 \quad 7.5$ 88.712 .5 9 129.9999 .999 .999 .9

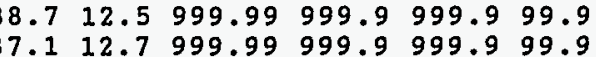
$\begin{array}{llllll}87.1 & 12.7 & 999.99 & 999.9 & 999.9 & 99.9\end{array}$

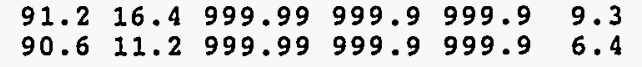


COMPUTER IISTING OF 1991 RAW DATA

PID

1549

1552

1553

1558

1559

1560

156

156

1567

157

1573

2102

2103

104

107

2108

2111

211

2114

2115

117

119

212

212

2132

2138

2139

2142

214

2145

2149

2150

2152

2158

2162

2167

2171

2171

2172

2176

SEX AGE

38

161

1
1

WBC PMN BAND IYMPH MONO

$6200 \quad 3100$

$5800 \quad 3364$

$5800 \quad 2958$

$5600 \quad 2184$

$7500 \quad 3375$

$4500 \quad 2115$

$8700 \quad 4524$

$4000 \quad 1760$

$6400 \quad 3776$

$6000 \quad 2460$

$8300 \quad 4814$

$5100 \quad 2703$

$6200 \quad 4030$

$10000 \quad 5500$

$11800 \quad 7080$

$12400 \quad 5952$

5100
5600
9621

$9000 \quad 6300$

$9000 \quad 6300$

$\begin{array}{ll}7600 & 4788 \\ 7500 & 4725\end{array}$

7500
8800
8925
8200

$8200 \quad 4510$

$\begin{array}{ll}5800 & 3132 \\ 7900 & 4503\end{array}$

$\begin{array}{ll}7900 & 4503 \\ 7500 & 3975\end{array}$

$\begin{array}{ll}7500 & 3975 \\ 8100 & 4698\end{array}$

$\begin{array}{ll}8100 & 4698 \\ 4600 & 2622\end{array}$

4600
6700
6952

66003828

$7700 \quad 4466$

$4500 \quad 2250$

$7200 \quad 5472$

$5300 \quad 2491$

$4900 \quad 2491$

$4900 \quad 2499$

$6700 \quad 4087$

$6900 \quad 3657$

4800
$6800 \quad 3332$

104007904

$5500 \quad 2365$

$10300 \quad 7004$

$5200 \quad 1456$

$6500 \quad 2925$

$8900 \quad 4895$

$5800 \quad 3364$

$\begin{array}{ll}8400 & 4536 \\ 5500 & 2365\end{array}$

$\begin{array}{rrrrr}0 & 2604 & 186 & 248 & 62 \\ 0 & 1914 & 232 & 232 & 0 \\ 0 & 1972 & 348 & 290 & 174 \\ 0 & 2296 & 224 & 616 & 280 \\ 0 & 2400 & 675 & 150 & 0\end{array}$

$\begin{array}{llll}0 & 306 & 43.1 & 5.00 \\ 0 & 298 & 43.5 & 5.02\end{array}$

$\begin{array}{lllll}174 & 371 & 42.5 & 4.56\end{array}$

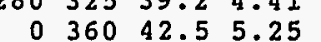

$\begin{array}{lllll}75 & 195 & 39.6 & 4.19\end{array}$

$\begin{array}{llll}0 & 279 & 43.3 & 4.85\end{array}$

$\begin{array}{llll}174 & 274 & 38.4 & 4.46 \\ 120 & 338 & 32.7 & 3.78\end{array}$

$\begin{array}{llll}128 & 206 & 48.2 & 5.69\end{array}$

$\begin{array}{llll}120 & 197 & 49.1 & 5.32\end{array}$

$166 \begin{array}{llll}0 & 371 & 38.3 & 4.27 \\ 0 & 297 & 36.7 & 5.00\end{array}$

$\begin{array}{llll}0 & 297 & 35.8 & 3.82\end{array}$

$\begin{array}{rrrr}62 & 274 & 35.6 & 3.89 \\ 0 & 407 & 38.1 & 4.37\end{array}$

$\begin{array}{rrrrr}0 & 407 & 38.1 & 4.37 \\ 18 & 274 & 45.5 & 5.48\end{array}$

$\begin{array}{lllllll}248 & 250 & 39.3 & 4.59 & 85.6 & 13.7\end{array}$

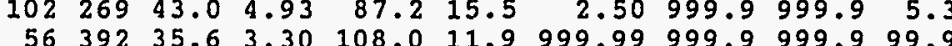
$\begin{array}{llllll}0 & 374 & 37.8 & 4.71 & 80.3 & 13.5\end{array}$

$\begin{array}{llllll}76 & 362 & 36.6 & 4.69 & 78.0 & 12.6\end{array}$

$\begin{array}{lllllll}75 & 249 & 39.7 & 4.60 & 86.3 & 13.5\end{array}$

$\begin{array}{lllllll}9999 & 999 & 53.2 & 6.01 & 89.0 & 17.1\end{array}$

$\begin{array}{llllll}328 & 288 & 42.2 & 4.75 & 88.9 & 14.8\end{array}$

$\begin{array}{llllll}0 & 292 & 41.3 & 4.64 & 89.1 & 14.3\end{array}$

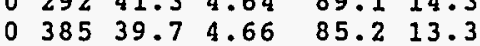

$\begin{array}{lllllll}81 & 210 & 37.2 & 4.31 & 86.2 & 12.6\end{array}$

$\begin{array}{lllllll}92 & 232 & 38.4 & 4.61 & 83.3 & 13.2\end{array}$

$\begin{array}{lllllll}67 & 287 & 42.8 & 5.03 & 85.0 & 14.7\end{array}$

$\begin{array}{lllllll}0 & 340 & 41.4 & 4.50 & 92.0 & 14.0\end{array}$

$\begin{array}{llllll}154 & 449 & 37.2 & 4.38 & 85.0 & 12.6\end{array}$

$\begin{array}{llllll}0 & 310 & 34.5 & 3.74 & 92.3 & 11.5\end{array}$

$\begin{array}{llllll}0 & 172 & 44.1 & 4.83 & 91.4 & 16.1\end{array}$

$\begin{array}{llllll}0 & 328 & 42.0 & 5.13 & 81.9 & 13.8\end{array}$

9829741.34 .5193 .618 .1

$\begin{array}{llllll}0 & 367 & 32.1 & 3.88 & 82.7 & 11.2\end{array}$

$\begin{array}{llllll}0 & 277 & 33.9 & 3.72 & 91.0 & 12.0\end{array}$

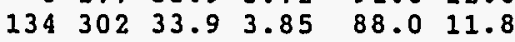

$\begin{array}{llllll}0 & 243 & 50.0 & 5.93 & 84.3 & 17.2\end{array}$

$\begin{array}{llllll}144 & 277 & 43.6 & 4.80 & 90.8 & 15.3\end{array}$

$\begin{array}{llllll}0 & 281 & 51.3 & 5.93 & 86.3 & 17.3\end{array}$

$\begin{array}{lllllll}104 & 230 & 44.1 & 4.81 & 91.6 & 15.5\end{array}$

$\begin{array}{lllllll}110 & 308 & 40.2 & 4.60 & 87.3 & 13.6\end{array}$

$\begin{array}{lllllll}0 & 288 & 41.2 & 4.66 & 88.5 & 14.0\end{array}$

$\begin{array}{llllll}0 & 303 & 36.3 & 4.43 & 81.9 & 11.8\end{array}$ $\begin{array}{lllllll}130 & 227 & 43.0 & 4.94 & 87.0 & 15.4\end{array}$ $\begin{array}{lllllll}178 & 313 & 39.1 & 4.55 & 86.0 & 13.1\end{array}$

$\begin{array}{llllll}58 & 241 & 42.6 & 4.83 & 88.3 & 14.3\end{array}$

$\begin{array}{llllll}168 & 349 & 46.2 & 5.37 & 86.1 & 16.3\end{array}$

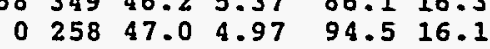

TSH PRL FBS HBAIC

$99.9 \quad 999.9 \quad 99.9$ 99999.9999 .999 .9 $2.20 \quad 999.9 \quad 999.9 \quad 99.9$ $\begin{array}{rrrr}.99 & 23.9 & 999.9 & 99.9\end{array}$ $\begin{array}{llll}9.99 & 2.9 & 85.0 & 4.4\end{array}$ 1.80999 .9999 .999 .9

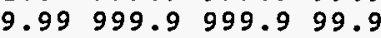
.99999 .9999 .999 .9 $\begin{array}{llll}3.30 & 999.9 & 999.9 & 99.9\end{array}$ $\begin{array}{llll}2.00 & 8.9 & 101.0 & 99.9\end{array}$ $.70 \quad 999.9 \quad 106.099 .9$ $4.50 \quad 999.9 \quad 161.0 \quad 4.2$ $\begin{array}{llll}1.60 & 999.9 & 999.9 & 99.9\end{array}$ $1.50 \quad 999.9 \quad 99.0 \quad 5.5$ $\begin{array}{llll}60 & 999.9 & 144.0 & 4.9\end{array}$ 1.50999 .9999 .999 .9 2.30999 .9298 .010 .8 1.50999 .9282 .010 .7 $2.004 .186 .0 \quad 5.6$ $3.2099 .190 .0 \quad 5.6$ $1.10 \quad 999.9999 .9 \quad 99.9$ $\begin{array}{llll}2.60 & 8.8 & 999.9 & 99.9\end{array}$ $1.60 \quad 999.9 \quad 999.9 \quad 99.9$ $\begin{array}{llll}2.20 & 999.9 & 999.9 & 99.9\end{array}$ $1.80 \quad 99.9999 .999 .9$

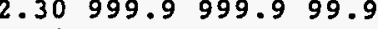
$1.90 \quad 999.9 \quad 999.9 \quad 99.9$ $1.00999 .9 \quad 999.999 .9$ $1.00 \quad 999.9 \quad 999.9 \quad 99.9$ $3.90 \quad 999.9999 .999 .9$ 1.70999 .9999 .999 .9 $3.90 \quad 5.5$. 4.00999 .9999 .999 .9 $2.30999 .9 \quad 999.9 \quad 99.9$ $1.20 \quad 999.9 \quad 332.0 \quad 6.5$ $2.20999 .9 \quad 999.9 \quad 99.9$ $1.30 \quad 999.9209 .0 \quad 9.7$ .70999 .9999 .999 .9 $\begin{array}{llll}1.00 & 999.9 & 105.0 & 5.0\end{array}$ $\begin{array}{llll}1.30 & 999.9 & 255.0 & 8.6\end{array}$ $2.50999 .9 \quad 999.9 \quad 99.9$ $3.90 \quad 4.6 \quad 999.9 \quad 99.9$ .20999 .9999 .999 .9 4.80999 .99909 2.10990 .328 .011 1.60999 .9999 .999 .9 $1.30999 .9249 .0 \quad 10.1$ 2.80 
COMPUTER IISTING OF 1991 RAW DATA

$\begin{array}{rrr}\text { PID } & \text { SEX } & \text { AG } \\ 2179 & 1 & 4 \\ 2182 & 2 & 89 \\ 2188 & 1 & 3 \\ 2193 & 2 & 68 \\ 2195 & 2 & 6 \\ 2196 & 2 & 7 \\ 2197 & 2 & 3 \\ 2205 & 1 & 6 \\ 2206 & 1 & 6 \\ 2207 & 1 & 4 \\ 2208 & 2 & 7 \\ 2209 & 2 & 4 \\ 2210 & 2 & 3 \\ 2215 & 2 & 7 \\ 2216 & 2 & 7 \\ 2217 & 2 & 5 \\ 2220 & 2 & 6 \\ 2221 & 2 & 8 \\ 2224 & 2 & 6 \\ 2225 & 2 & 4 \\ 2227 & 2 & 4 \\ 2228 & 2 & 4 \\ 2229 & 2 & 5 \\ 2230 & 2 & 4 \\ 2231 & 2 & 3 \\ 2232 & 1 & 3 \\ 2233 & 1 & 3 \\ 2235 & 1 & 4 \\ 2236 & 1 & 4 \\ 2237 & 1 & 4 \\ 2239 & 2 & 4 \\ 2244 & 2 & 8 \\ 2247 & 2 & 45 \\ 2248 & 2 & 5 \\ 2251 & 2 & 4 \\ 2254 & 2 & 4 \\ 2256 & 2 & 4 \\ 2257 & 1 & 4 \\ 2260 & 2 & 3 \\ 2261 & 1 & 6 \\ 2269 & 1 & 3 \\ 2271 & 1 & 3 \\ 2273 & 1 & 3 \\ 2274 & 1 & 3 \\ & & \end{array}$

$\begin{array}{rrrrrr}\text { WBC } & \text { PMN } & \text { BAND } & \text { LYMPH } & \text { MONO } & \text { EOS } \\ 7500 & 3900 & 0 & 3000 & 375 & 225 \\ 4100 & 2501 & 0 & 1189 & 164 & 246 \\ 4700 & 2726 & 0 & 1504 & 282 & 188 \\ 5200 & 3172 & 0 & 988 & 156 & 832 \\ 6200 & 2852 & 0 & 2108 & 372 & 806 \\ 8200 & 3608 & 0 & 3526 & 246 & 820 \\ 5200 & 3120 & 0 & 1820 & 260 & 0 \\ 6700 & 2680 & 0 & 2948 & 603 & 469 \\ 5900 & 2773 & 59 & 1947 & 295 & 767 \\ 6400 & 2624 & 128 & 2624 & 384 & 576 \\ 8900 & 6497 & 0 & 1691 & 267 & 445 \\ 7400 & 5920 & 0 & 1110 & 74 & 148 \\ 7500 & 4200 & 0 & 1950 & 375 & 975 \\ 8300 & 3901 & 83 & 3403 & 166 & 747 \\ 2000 & 7920 & 0 & 3360 & 600 & 120 \\ 6100 & 3660 & 0 & 1891 & 244 & 305 \\ 6800 & 4556 & 68 & 1836 & 68 & 204 \\ 4700 & 2209 & 47 & 1833 & 423 & 188 \\ 6800 & 4148 & 0 & 1564 & 68 & 1020 \\ 9100 & 5187 & 0 & 2730 & 91 & 910 \\ 7500 & 4875 & 0 & 2100 & 225 & 300 \\ 2700 & 6985 & 0 & 2921 & 635 & 1905 \\ 7300 & 4015 & 0 & 2409 & 511 & 292 \\ 7800 & 5148 & 78 & 1872 & 546 & 156 \\ 5800 & 3770 & 0 & 1798 & 174 & 58 \\ 7000 & 2940 & 0 & 3290 & 280 & 490 \\ 6300 & 2835 & 0 & 2583 & 0 & 882 \\ 6600 & 3894 & 0 & 1650 & 594 & 330 \\ 9100 & 6734 & 0 & 1638 & 546 & 182 \\ 6300 & 3969 & 63 & 1701 & 441 & 189 \\ 7400 & 4366 & 0 & 1850 & 370 & 666 \\ 3700 & 1110 & 37 & 2109 & 222 & 222 \\ 8000 & 4000 & 80 & 2720 & 640 & 560 \\ 8300 & 4814 & 0 & 2324 & 332 & 747 \\ 10500 & 6720 & 0 & 2835 & 525 & 420 \\ 4800 & 2496 & 0 & 1536 & 192 & 576 \\ 5500 & 3465 & 0 & 1540 & 275 & 220 \\ 7200 & 4752 & 0 & 1872 & 504 & 0 \\ 7800 & 2964 & 0 & 3666 & 312 & 780 \\ 5000 & 3000 & 50 & 1500 & 200 & 250 \\ 7700 & 3465 & 0 & 2772 & 308 & 1078 \\ 6000 & 2520 & 0 & 2580 & 120 & 660 \\ 7900 & 4345 & 0 & 3160 & 79 & 237 \\ 8800 & 5104 & 0 & 2816 & 440 & 352 \\ & & & & & \end{array}$

BASO PLT HCT RBC MCV HGB $\begin{array}{llllll}0 & 291 & 50.2 & 6.10 & 82.3 & 17.0\end{array}$ $\begin{array}{llllll}0 & 307 & 31.9 & 3.55 & 89.8 & 11.1\end{array}$ $\begin{array}{llllll}0 & 172 & 48.6 & 5.50 & 88.3 & 16.1\end{array}$ $\begin{array}{llllll}52 & 249 & 32.4 & 3.60 & 90.1 & 11.3\end{array}$ 0037936.54 .5736 .112 .6 $\begin{array}{llllll}0 & 379 & 36.5 & 4.23 & 86.4 & 12.5\end{array}$ $\begin{array}{llllll}0 & 9.99 & 37.1 & 4.09 & 91.0 & 12.2\end{array}$ $\begin{array}{llllll}59 & 268 & 40.0 & 4.52 & 88.4 & 13.9\end{array}$ $\begin{array}{lllllll}59 & 268 & 40.0 & 4.52 & 88.4 & 13.9 \\ 64 & 237 & 44.6 & 5.38 & 82.9 & 14.9\end{array}$ $\begin{array}{rlllll}64 & 237 & 44.6 & 5.38 & 82.9 & 14.9 \\ 0 & 380 & 41.4 & 4.77 & 86.8 & 14.6\end{array}$ $\begin{array}{rllllll}0 & 380 & 41.4 & 4.77 & 86.8 & 14.6 \\ 48 & 459 & 34.5 & 4.07 & 84.7 & 12.3\end{array}$ $\begin{array}{rllllll}148 & 459 & 34.5 & 4.07 & 84.7 & 12.3 \\ 0 & 428 & 40.2 & 4.87 & 82.6 & 13.6\end{array}$ $\begin{array}{lllllll}0 & 414 & 37.5 & 4.39 & 85.5 & 12.5\end{array}$ $\begin{array}{lllllll}0 & 554 & 40.1 & 4.84 & 82.9 & 13.5\end{array}$ $\begin{array}{lllllll}0 & 271 & 35.9 & 3.97 & 90.5 & 12.4\end{array}$ $\begin{array}{lllllll}68 & 278 & 38.9 & 4.32 & 90.0 & 13.6\end{array}$ $\begin{array}{llllllll}0 & 170 & 29.2 & 3.00 & 97.3 & 10.2\end{array}$

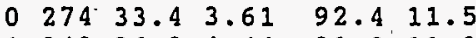
$\begin{array}{llllll}91 & 348 & 36.3 & 4.44 & 81.8 & 11.8\end{array}$ $\begin{array}{lllllll}0 & 416 & 35.1 & 4.62 & 75.9 & 11.4\end{array}$ $\begin{array}{lllllll}254 & 405 & 39.1 & 4.57 & 85.6 & 13.4\end{array}$ $\begin{array}{lllllll}73 & 287 & 41.6 & 4.76 & 87.4 & 14.5\end{array}$ $\begin{array}{lllllll}0 & 330 & 44.0 & 5.37 & 82.0 & 14.6\end{array}$ $\begin{array}{lllllll}0 & 468 & 39.7 & 4.93 & 80.5 & 13.7\end{array}$

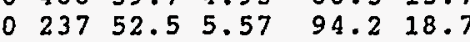
$\begin{array}{llllll}0 & 247 & 46.4 & 5.00 & 92.7 & 15.7\end{array}$ $\begin{array}{lllllll}132 & 285 & 41.3 & 4.71 & 87.6 & 14.9\end{array}$ $\begin{array}{lllllll}0 & 999 & 41.9 & 5.06 & 82.9 & 14.3\end{array}$ $\begin{array}{llllll}0 & 390 & 44.8 & 5.02 & 89.2 & 15.5\end{array}$ $\begin{array}{lllllll}74 & 372 & 39.2 & 4.52 & 86.7 & 13.5\end{array}$ $\begin{array}{lllllll}0 & 239 & 33.5 & 3.55 & 94.3 & 11.2\end{array}$ $\begin{array}{lllllll}0 & 317 & 35.1 & 4.36 & 80.6 & 11.5\end{array}$ $83 \quad 303 \quad 38.9 \quad 4.63$ $\begin{array}{lllll}0 & 482 & 36.9 & 4.55\end{array}$ $\begin{array}{llll}0 & 351 & 38.3 & 4.80\end{array}$ $\begin{array}{lllll}0 & 424 & 31.3 & 3.76\end{array}$ $\begin{array}{llll}72 & 265 & 44.2 & 5.44\end{array}$ $\begin{array}{llll}8 & 389 & 41.3 & 4.84\end{array}$ $\begin{array}{rrrrr}0 & 212 & 49.6 & 5.43 \\ 77 & 299 & 46.3 & 5.09\end{array}$ $\begin{array}{llll}120 & 377 & 46.2 & 5.44\end{array}$ $\begin{array}{llllll}88 & 316 & 48.5 & 5.61 & 86.4 & 16.1\end{array}$
TSH PRI FBS HBAIC

$\begin{array}{llll}1.10 & 9.8 & 999.9 & 5.7\end{array}$ $2.30 \quad 999.9 \quad 999.9 \quad 99.9$ $\begin{array}{rrrr}1.40 & 999.9 & 182.0 & 6.2\end{array}$ $\begin{array}{llll}.80 & 999.9 & 999.9 & 99.9\end{array}$ $\begin{array}{llll}1.90 & 999.9 & 242.0 & 7.8\end{array}$ $\begin{array}{llll}0.00 & 999.9 & 107.0 & 4.8\end{array}$ $\begin{array}{llll}6.90 & 24.7 & 999.9 & 99.9\end{array}$ 1.00999 .9 .999 .96 .6 $.60999 .9 \quad 999.9 \quad 99.9$ $\begin{array}{llll}1.30 & 999.9 & 232.0 & 99.9\end{array}$ $\begin{array}{llll}3.60 & 999.9 & 999.9 & 8.5\end{array}$ $1.20 \quad 999.9999 .999 .9$ $\begin{array}{llll}1.20 & 999.9 & 95.0 & 6.8\end{array}$ $1.30 \quad 999.9 \quad 163.0 \quad 99.9$ $2.20 \quad 19.3 \quad 999.9 \quad 99.9$ $2.30 \quad 999.9 \quad 999.9 \quad 99.9$ $\begin{array}{llll}6.50 & 999.9 & 76.0 & 4.7\end{array}$ $11.30 \quad 20.3 \quad 999.9 \quad 99.9$ $1.80 \quad 999.9 \quad 999.9 \quad 99.9$ $5.30 \quad 999.9 \quad 999.9 \quad 99.9$ $2.60 \quad 999.9 \quad 999.9 \quad 99.9$ 1.70999 .9999 .9 .99 .9

$\begin{array}{llll}90 & 999.9 & 999.9 & 5.3\end{array}$

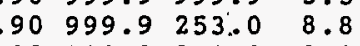
$.90 \quad 999.9999 .9 \quad 9.8$ $\begin{array}{rrrr}4.20 & 6.1 & 999.9 & 99.9\end{array}$ $2.60 \quad 999.9 \quad 999.9 \quad 5.4$ $\begin{array}{llll}.70 & 999.9 & 90.0 & 4.5\end{array}$ $\begin{array}{llll}5.10 & 999.9 & 999.9 & 99.9\end{array}$ $\begin{array}{llll}2.20 & 999.9 & 90.0 & 99.9\end{array}$ $4.00 \quad 999.9 \quad 999.9 \quad 99.9$ $\begin{array}{llll}2.20 & 999.9 & 111.0 \quad 4.7\end{array}$ $.90 \quad 999.9 \quad 999.9 \quad 99.9$ $\begin{array}{lllll}26.50 & 999.9 & 120.0 & 7.6\end{array}$ $15.00 \quad 999.9 \quad 999.9 \quad 99.9$ $4.60 .999 .9 \quad 999.999 .9$ 1.5009 .6424 .00 $.80 \quad 7.6 \quad 999.999 .9$ $1.20 \quad 57.899 .999 .9$ 3.20 .999 .999 .90 .9 2.509 .99 .9999 .999 .9 $2.70 \quad 999.9274 .0 \quad 8.8$ $\begin{array}{rrrr}1.00 & 999.9 & 999.9 & 99.9 \\ 2.60 & 999.9 & 114.0 & 6.6\end{array}$ 


\section{APPENDIX C}

\section{THYROID SUMMARY}

This 35 year old male was 8 months in utero at the time of exposure to the fallout from Bravo. In October 1989 he was noted to have a thyroid nodule in the right thyroid isthmus. He was referred to the NIH for additional evaluation. Physical examination revealed a right sided inferior thyroid nodule approximately $0.8 \mathrm{~cm}$ in diameter. The thyroid was of granular consistency and the remainder of the physical examination was unremarkable. Thyroid function tests were within normal limits, including a serum TSH. Ultrasound of the neck showed a large nodule. Technetium thallium scan showed a cold nodule in the lower pole of the right thyroid. Fine needle aspiration showed blood elements, no follicular cells were seen. The patient underwent a right thyroid lobectomy on 12/7/89. Pathology from the right hemithyroidectomy showed a $6 \times 3 \times 2.5 \mathrm{~cm}$ specimen containing a $1 \mathrm{~cm}$ hemorrhagic cyst with a $0.5 \mathrm{~cm}$ papillary growth within the cyst. Frozen section showed a benign hypertrophic nodule with papillary proliferation and hemorrhage. This was confirmed as a colloid cyst by permanent section. Two foci of micropapillary carcinoma, separate from the nodule, were detected. The patient was placed on suppressive Synthroid and no additional surgery was performed. Currently the patient is on Synthroid $0.2 \mathrm{mg}$. q.d. and is doing well. 


\section{APPENDIX D}

This table lists all exposed persons who have had surgery which confirmed a thyroid lesion, their ages at the time of surgery, the number of years post-exposure that thyroid surgery was performed, and the thyroid-absorbed radiation dose in cGy. The code for "Nodule type" is: 1 = adenomatous nodule; 2 = adenoma; 3 = occult papillary carcinoma; $4=$ overt carcinoma. In some instances there was a divided opinion as to the pathologic diagnosis; for the purposes of this table the "more malignant' diagnosis has been used (i.e., overt carcinoma > occult papillary carcinoma > adenoma > adenomatous goiter). * represents Rongelap individuals; ${ }^{* *}$ represents Utirik individuals

\begin{tabular}{|c|c|c|c|c|c|c|c|c|}
\hline & $\begin{array}{l}\text { Age in } \\
1954\end{array}$ & Sex & $\begin{array}{l}\text { Age at } \\
\text { Surgery }\end{array}$ & $\begin{array}{l}\text { Years post-' } \\
\text { exposure }\end{array}$ & $\begin{array}{l}\text { Internal } \\
\text { dose }\end{array}$ & $\begin{array}{l}\text { External } \\
\text { dose }\end{array}$ & $\begin{array}{l}\text { Total } \\
\text { dose }\end{array}$ & $\begin{array}{l}\text { Nodule } \\
\text { Type }\end{array}$ \\
\hline$*$ & 1 & $\mathbf{M}$ & 12 & 11 & 5000 & 190 & 5190 & 1 \\
\hline$*$ & 2 & $F$ & 20 & 18 & 1040 & 110 & 1150 & 1 \\
\hline$*$ & 6 & $\mathrm{~F}$ & 21 & 15 & 2400 & 190 & 2590 & 1 \\
\hline * & 3 & $\mathbf{F}$ & 13 & 10 & 3500 & 190 & 3690 & 1 \\
\hline$*$ & 19 & $F$ & 34 & 15 & 1100 & 190 & 1290 & 4 \\
\hline * & 5 & $\mathbf{M}$ & 19 & 14 & 2700 & 190 & 2890 & 1 \\
\hline * & 7 & $\mathrm{M}$ & 18 & 11 & 2300 & 190 & 2490 & 1 \\
\hline * & 3 & $\mathrm{~F}$ & 13 & 10 & 3500 & 190 & 3690 & 1 \\
\hline$*$ & 3 & $\mathbf{M}$ & 17 & 14 & 3500 & 190 & 3690 & 1 \\
\hline * & 2 & $\mathbf{F}$ & 14 & 12 & 4000 & 190 & 4190 & 1 \\
\hline * & 7 & $\mathbf{M}$ & 22 & 15 & 2300 & 190 & 2490 & 1 \\
\hline * & 3 & $\mathbf{F}$ & 15 & 12 & 3500 & 190 & 3690 & 1 \\
\hline * & 30 & $F$ & 49 & 19 & 290 & 110 & 400 & 1 \\
\hline * & 23 & $\mathrm{~F}$ & 43 & 20 & 290 & 110 & 400 & 2 \\
\hline * & 7 & $\mathrm{~F}$ & 33 & 26 & 600 & 110 & 710 & 1,3 \\
\hline * & $i$ & $M$ & 15 & 14 & 5000 & 190 & 5190 & 1 \\
\hline * & 34 & $\mathrm{~F}$ & 46 & 12 & 290 & 110 & 400 & 1 \\
\hline * & 8 & $\mathbf{F}$ & 20 & 12 & 2200 & 190 & 2390 & 1 \\
\hline$*$ & 28 & $\mathbf{F}$ & 39 & 11 & 1100 & 190 & 1290 & 4 \\
\hline$*$ & 1 & $\mathbf{F}$ & 13 & 12 & 5000 & 190 & 5190 & 1 \\
\hline$*$ & 28 & $\mathbf{F}$ & 53 & 25 & 1100 & 190 & 1290 & 1 \\
\hline$*$ & 14 & $\mathbf{F}$ & 45 & 31 & 1400 & 190 & 1590 & 4 \\
\hline$*$ & 4 & $\mathbf{F}$ & 45 & 31 & 1400 & 190 & 1590 & 4 \\
\hline
\end{tabular}




\begin{tabular}{|c|c|c|c|c|c|c|c|c|}
\hline * & 7 & $\mathbf{F}$ & 22 & 15 & 2300 & 190 & 2490 & 4 \\
\hline$*$ & 16 & $\mathbf{F}$ & 38 & 22 & 1300 & 190 & 1490 & 4 \\
\hline$*$ & 12 & $\mathbf{F}$ & 30 & 18 & 2600 & 190 & 1790 & 1,2 \\
\hline * & 0.7 & $\mathbf{M}$ & 20 & 19 & 680 & 190 & 870 & 1 \\
\hline * & 0.3 & $\mathbf{M}$ & 25 & 25 & 0 & 190 & 190 & 1 \\
\hline$* *$ & 1 & $\mathbf{F}$ & 28 & 27 & 670 & 11 & 681 & 1 \\
\hline ** & 5 & F & 30 & 25 & 390 & 11 & 401 & 1 \\
\hline ** & 11 & $\mathbf{M}$ & 33 & 22 & 260 & 11 & 271 & 2 \\
\hline$* *$ & 17 & $\mathbf{M}$ & 47 & 30 & 150 & 11 & 161 & 4 \\
\hline$* *$ & 3 & $F$ & 24 & 21 & 480 & 11 & 491 & 4 \\
\hline$* *$ & 14 & $\mathbf{M}$ & 44 & 30 & 220 & 11 & 231 & 3 \\
\hline ** & 2 & $\mathrm{~F}$ & 32 & 30 & 550 & 11 & 561 & 4 \\
\hline$* *$ & 12 & $\mathbf{F}$ & 32 & 20 & 240 & 11 & 251 & 2 \\
\hline$* *$ & 31 & $\mathbf{F}$ & 56 & 25 & 160 & 11 & 171 & 1 \\
\hline$* *$ & 35 & $\mathbf{F}$ & 57 & 22 & 260 & 11 & 171 & 4 \\
\hline$* *$ & 24 & $\mathbf{F}$ & 49 & 25 & $160^{\circ}$ & 11 & 171 & 1 \\
\hline$* *$ & 38 & $F$ & 64 & $26^{\circ}$ & 160 & 11 & 171 & 1 \\
\hline$* *$ & 3 & $\mathbf{F}$ & 34 & 31 & 480 & 11 & 491 & 3 \\
\hline$* *$ & 37 & $\mathbf{F}$ & 56 & 19 & 160 & 11 & 171 & 1 \\
\hline$* *$ & 34 & $\mathbf{F}$ & 53 & 19 & 160 & 11 & 171 & 1 \\
\hline$* *$ & 33 & $\mathbf{F}$ & 58 & 25 & 160 & 11 & 171 & 1,3 \\
\hline$* *$ & 52 & F & 71 & 19 & 160 & 11 & 171 & 1 \\
\hline$* *$ & 6 & $\mathbf{F}$ & 37 & 31 & 340 & 11 & 351 & 1 \\
\hline$* *$ & 18 & $\mathbf{F}$ & 33 & 15 & 160 & 11 & 171 & 4 \\
\hline ** & 11 & $\mathbf{M}$ & 35 & 24 & 260 & 11 & 271 & 2 \\
\hline ** & 3 & F & 30 & 27 & 480 & 11 & 491 & 2 \\
\hline$* *$ & 15 & $\mathbf{F}$ & 44 & 29 & 200 & 11 & 211 & 3 \\
\hline$* *$ & 4 & $\mathbf{F}$ & 36 & 32 & 430 & 11 & 441 & 2,3 \\
\hline$* *$ & 0.9 & $\mathbf{M}$ & 35 & 34 & 98 & 11 & 109 & 3 \\
\hline
\end{tabular}

